Portland State University

PDXScholar

Spring 6-2-2016

\title{
Stranding Mortality Patterns in California Sea Lions and Steller Sea Lions in Oregon and Southern Washington, 2006 to 2014
}

Kessina Lee

Portland State University

Follow this and additional works at: https://pdxscholar.library.pdx.edu/open_access_etds

Part of the Biology Commons

Let us know how access to this document benefits you.

Recommended Citation

Lee, Kessina, "Stranding Mortality Patterns in California Sea Lions and Steller Sea Lions in Oregon and Southern Washington, 2006 to 2014" (2016). Dissertations and Theses. Paper 2995.

https://doi.org/10.15760/etd.2996

This Thesis is brought to you for free and open access. It has been accepted for inclusion in Dissertations and Theses by an authorized administrator of PDXScholar. Please contact us if we can make this document more accessible: pdxscholar@pdx.edu. 
Stranding Mortality Patterns in California Sea Lions and Steller Sea Lions in Oregon and Southern Washington, 2006 to 2014

by
Kessina Lee

A thesis submitted in partial fulfillment of the requirements for the degree of

\author{
Master of Science \\ in \\ Biology
}

Thesis Committee:

Deborah Duffield, Chair

Luis Ruedas

David Banis

Portland State University

2016 
(C) 2016 Kessina Lee 


\begin{abstract}
As changing ocean conditions lead to declining fish stocks and movement of forage fish, sea lions on the Oregon coast are subject to the pressures of declining prey availability and increasing conflicts with commercial and recreational fisheries. An analysis of strandings of California sea lions, Zalophus californianus, and Steller sea lions, Eumetopias jubatus, from 2006 to 2014, included cause of death, changing ocean conditions, and anthropogenic activity. Causes of death included disease, injury, and human interaction, such as gunshot wounds, fisheries net entanglements and boat strikes.
\end{abstract}

Oregon and Washington strandings of California sea lions are primarily adult and subadult males that migrate north from California rookeries, while Steller sea lions are year-round residents and strandings are comprised of males and females of all ages. While the California sea lion population is currently at or near carrying capacity, the Eastern Pacific population of Steller sea lions was designated as Threatened under the Endangered Species Act until October 2013. Understanding impacts to these two pinniped species is vital to implementing effective management and conservation policies.

Oregon and southern Washington strandings of California sea lions and Steller sea lions from 2006 to 2014 were analyzed spatially using the geographic information system (GIS), and temporally to identify possible correlations with prey 
availability and human interaction. Strandings were found to follow seasonal patterns from year to year: Steller sea lion strandings were highest from May to July, California sea lions peaked in September, October, and November. There was a correlation between significantly high numbers of strandings and the three largest commercial fisheries in Oregon: Chinook salmon, Coho salmon, and Dungeness crab.

This analysis provides a format for continuing to monitor primary ecological and anthropogenic drivers of pinniped mortality in Oregon and southern Washington. 
For my parents, who raised me on a balanced diet of outdoor exploration and the inside of libraries, and for my sons, who make me want to be better. 
Acknowledgements:

I am sincerely grateful to:

Scott Benjamin for his love and support, and Simon for keeping me company;

Everett, Clayton, and Eli for always making me laugh and letting me know they're proud of me;

Deb Duffield for her patience with my lengthy process, and her unfailing support and encouragement;

My committee: Luis Ruedas and David Banis for helping me bring this thing home;

Keith Cameron McKinnon for being my GIS superhero;

Matt Tennis for generously sharing his sea lion counts and, along with Dan Heiner, teaching me how to apply a flipper tag;

James Powell and Kyle Tidwell--it's a Duffield Lab thing;

The BioBabes: Catherine Dayger, Christina Howard, and Claire Riggs, for the friendship, commiseration, brunches, and science love. 
Table of Contents

Abstract

Chapter 2: Assessing spatial and temporal distributions of sea lion strandings in Oregon and southern Washington, 2006-2014 ……………………………...... 19

Chapter 3: Characterization of sea lion strandings by cause of death, environmental factors, and anthropogenic activities ................................................................... 35

Chapter 4: Discussions and Conclusions ........................................ 55

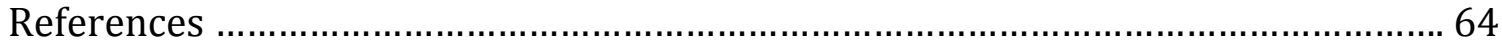
Appendices

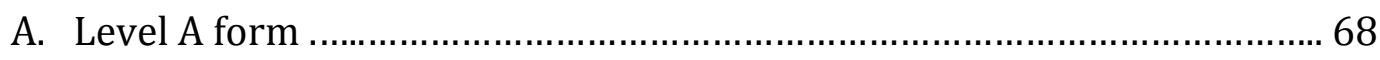

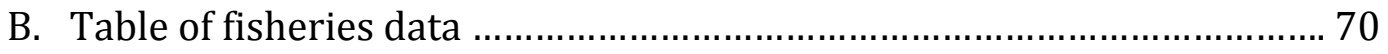




\section{List of Tables}

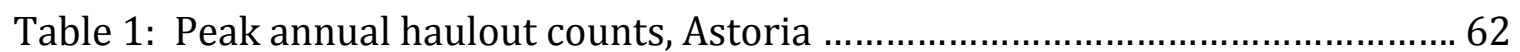


List of Figures

Figure 1.1: Proportion of pinnipeds and cetacean strandings, 1989-2016 .............. 14

Figure 1.2: Map of Oregon stranding network regions ...................................... 15

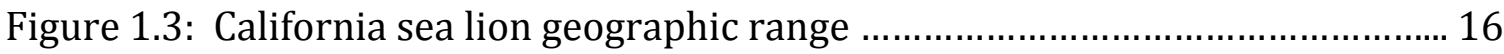

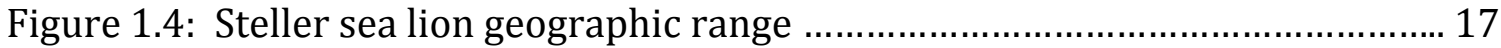

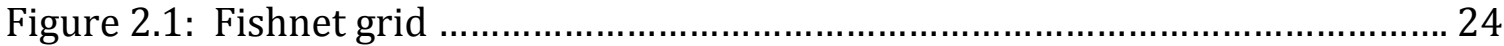

Figure 2.2: Incremental Spatial autocorrelation graph ..................................... 25

Figure 2.3: California and Steller sea lion strandings, 2006-2014, by year .............. 26

Figure 2.4: California and Steller sea lion strandings, 2006-2014, by month .......... 26

Figure 2.5: California and Steller sea lion strandings, 2006-2014, by species ......... 27

Figure 2.6: PSU California and Steller sea lion strandings, 2006-2014, by species.. 27

Figure 2.7: PSU Chi-square test- Steller sea lion ............................................ 28

Figure 2.8: PSU Chi-square test-California sea lion ........................................... 28

Figure 2.9: HMSC California and Steller sea lion strandings by species ................... 29

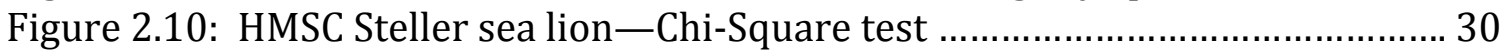

Figure 2.11: HMSC California sea lion--Chi-square test ...................................... 30

Figure 2.12: California sea lion strandings, 2006-2014, by age class ...................... 31

Figure 2.13: Steller sea lion strandings, 2006-2014, by age class .......................... 31

Figure 2.14: Maps of all strandings and Hot Spot Analysis, 2006-2014 ............ 32-34

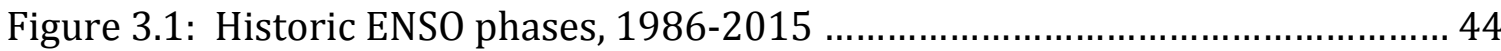

Figure 3.2: PSU strandings by COD ............................................................. 45

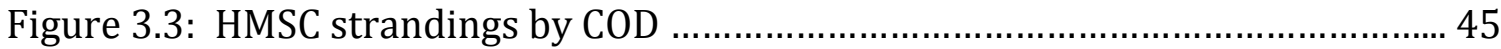

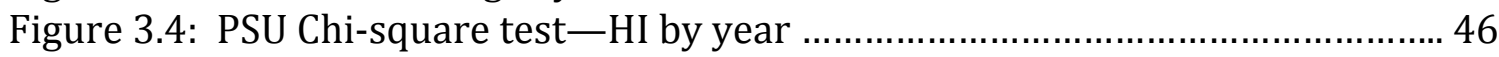

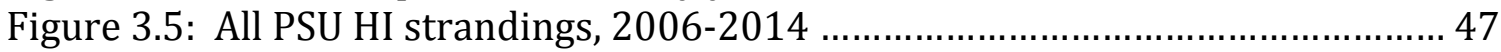

Figure 3.6: All California and Steller sea lion ILL strandings .................................. 47

Figure 3.7: Hot Spot Analysis--Steller sea lions, 2006-2014 ............................... 48

Figure 3.8: Hot Spot Analysis-California sea lions, 2006-2014 ....................... 49-51

Figure 3.9: HI strandings points, 2006-2014 .............................................. 52-54

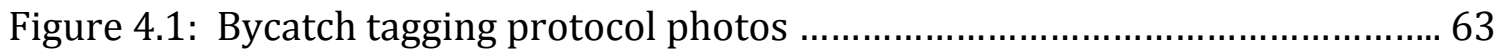




\section{CHAPTER 1: Introduction}

As global fish stocks decline and the effects of climate change accrue, it will become vitally important to understand what factors impact ocean health. The Health of the Ocean Panel of UNESCO (1996) defined ocean health as a "reflection of the condition of the marine environment from the perspective of adverse effects caused by anthropogenic activities, in particular habitat destruction, changed sedimentation rates and the mobilization of contaminants." Assessing the health of the marine environment is necessary to understanding what conservation measures and sustainable management practices are needed to ensure that the biodiversity of marine habitats is maintained and that critical habitats are preserved (Knap et al. 2002). Marine mammals play important roles in marine ecosystems as high trophic level predators and sentinel species, because seemingly small disturbances in the marine ecosystem may be amplified and manifest in health issues at higher trophic levels. As "conspicuous and charismatic megafauna," they are easily observed and engage public interest and concern (Bossart 2006).

Marine mammal stranding incidents on the Oregon and southern Washington coast fluctuate from year to year and by species, but pinnipeds comprise the majority of strandings, and California sea lions, Zalophus californianus, and Steller sea lions, Eumetopias jubatus, are two of the three most common pinniped species to strand (harbor seals, Phoca vitulina, are the other) (OMMSN personal communication, Fig. 1.1). Frequencies of strandings have been associated 
with environmental perturbations, such as storm surges and El Nino events (Dunlap 1995) and with unintentional and intentional human interactions (Grieg et al. 2005). Determining whether environmental variations, as well as anthropogenic impacts, correlate with California sea lion and Steller sea lion stranding events will help identify factors that may be considered indices of ocean health as it relates to these important marine predators.

\section{Background}

\section{Marine mammal strandings}

The Marine Mammal Health and Stranding Response Program (MMHSRP) was founded in 1992 as an extension of the Marine Mammal Protection Act of 1972. Stranding networks were established in all coastal states and are coordinated by NOAA's National Marine Fisheries Service. Two regional networks respond to stranding reports in Oregon: the Northern Oregon \& Southern Washington Stranding Program (NOSWSP) based at Portland State University (PSU), and the Central Oregon Marine Mammal Stranding Network based at Oregon State University's Hatfield Marine Science Center (HMSC) in Newport. Reports come from a variety of sources, including state and federal agencies, municipalities, and opportunistic reports from the public. In Oregon, there are no facilities for rescue and rehabilitation of marine mammals, thus for the purposes of this study, a 'stranded' marine mammal is an animal that is dead and beachcast at the time of the stranding network response. Stranding networks collect "Level A" data including location, species, decomposition condition, morphological data, and any 
observations related to the condition of the animal, as well as evidence of human interaction (Appendix A-Level A form).

Whenever possible, necropsies are performed to determine cause of death, to collect tissues for histopathology and to archive tissues for future research. Skeletal remains are collected for museum collections and for morphological studies. Liver, kidney, and blubber samples are collected for potential study of persistent contaminants and stomach contents yield information on foraging ecology. Necropsies also provide data on presence of disease, as well as human interactions such as net entanglements, ship strike, gunshot wounds, and ingestion of marine debris. These data collected by stranding networks contribute to national and international marine mammal biomonitoring efforts in order to assess marine mammal health and anthropogenic impacts on marine mammals and marine ecosystems.

Stranding networks respond to stranding reports as resources and staff capacity allows, although these efforts can prove difficult when a stranding network receives a large number of stranding reports over a considerable geographic distance. The HMSC network covers the coastline from the Oregon-California border to just south of Tillamook, Oregon, a distance of approximately 300 miles, with one full-time stranding network coordinator. The PSU network covers the coastline from just south of Tillamook to Astoria, Oregon at the mouth of the Columbia River, the Columbia River 146 river miles to Bonneville Dam, and Washington's 28-mile Long Beach Peninsula, for a total of approximately 240 miles (Fig. 1.2). The PSU network has a stranding coordinator and a stranding responder, and receives approximately 
half as many stranding reports per year as the HMSC network. Based on these differences in resources, geography, and volume of stranding reports, the PSU stranding network is able to necropsy nearly every beachcast marine mammal reported, whereas the HMSC network is able to gather enough data for Level A reports, but is unable to perform necropsies on the majority of stranded pinnipeds, necropsying only those fresh enough for histopathology.

\section{California sea lion}

The Oregon coast is home to several year-round resident populations of marine mammals, as well as species who migrate seasonally. California sea lions and Steller sea lions belong to the Order Carnivora, Family Otaridae. Both species exhibit significant sexual dimorphism and have polygynous breeding systems. California sea lions and Steller sea lions are gregarious outside of the breeding season, often aggregating in large numbers (particularly California sea lions) at haulout locations.

Male California sea lions can reach a length of 7'10" (2.4 m) and weigh 860 pounds (390 kg), females can grow to 6'7" (2 m) and weigh 240 pounds (110 kg). Estimates of female life span are 20-30 years with the males' lifespan slightly less. The distribution of California sea lions is limited to the coastal waters of the Eastern North Pacific ranging from the U.S.-Mexico border to Alaska (Fig. 1.3). Based on increasing reports of sightings of California sea lions in Alaska, their range seems to be expanding north (Szteren et al. 2006). The California population, distinct from the Gulf of California, Mexico population, breeds and pups at rookeries on the Channel Islands off the coast of southern California (Odell 1981). Males and females 
gather at rookeries in late spring and early summer, and breeding takes place in July and August following pupping. Males establish territory near the water's edge on sandy beaches or rocky ledges and guard a harem of females. Approximately three weeks following parturition (the females give birth to a single pup), the bull breeds the females. When breeding season is complete, adult and sub-adult males migrate north in the winter and spring along the Pacific Coast of North America as far north as British Columbia, and increasingly to Alaska, thus avoiding resource competition with the females and pups that remain near the rookeries or range south (Weise et al. 2006). In recent years, more male yearling and juvenile California sea lions are also migrating north (2014 stranding data), likely due to shifts in prey abundance associated with increasing sea surface temperatures.

Abundance estimates of California sea lions prior to the 1972 Marine Mammal Protection Act (MMPA) vary, but the population was severely depleted due to exploitation for pet food, target practice, bounty, hides, and reduction of fishery depredation. Since the MMPA the population numbers have increased to a current estimate of 387,646, which is thought to exceed carrying capacity (Aurioles-Gamboa \& Hernandez-Camacho 2015). California sea lions feed primarily in upwelling areas on prey such as squid, anchovies, mackerel, rockfish, hake, and sardines, as well as salmonids which they are known to take from commercial fishing gear, sport-fishing lines, and at dams and fish passage points in rivers (Norberg et al. 2005). As salmonid abundance in the Pacific Northwest has decreased and California sea lion abundance has increased, the degree of impact the sea lions have on threatened and endangered salmon and steelhead runs has been a subject of substantial study and 
controversy (Stansell et al. 2010). Federal and state agencies have employed a variety of methods aimed at reducing pinniped predation on these at-risk fish populations, including the authorization of lethal takes of individual California sea lions observed to be repeatedly preying on endangered salmon at Bonneville Dam on the Columbia River (Brown et al. 2007).

\section{Steller sea lion}

Steller sea lions are the largest member of the Family Otaridae with males reaching 11' (3.3 m) and 2400 pounds $(1,100 \mathrm{~kg})$ and females reaching 9'6" $(2.9 \mathrm{~m})$ and 770 pounds ( $350 \mathrm{~kg}$ ). Both sexes live approximately 18-25 years; males are perhaps slightly shorter-lived than females (Pitcher et al. 2007). The species is distributed through the North Pacific Ocean rim from Japan through the Bering Sea and south to the Channel Islands in California. There are considered to be two stocks, an Eastern and Western stock, divided at $144^{\circ} \mathrm{W}$ longitude (Calkins et al. 1982). Though not known to migrate, Steller sea lions range widely in the non-breeding seasons (Fig. 1.4). The western stock is listed as Endangered under the Endangered Species Act (ESA), while the eastern stock, which includes Oregon and Washington, was designated Threatened until October 2013, when they were delisted. The total population is estimated to be between 58,334-72,223 (NMFS 2013). Population surveys indicate that the Eastern stock is increasing slightly in Southeast Alaska and British Columbia, but declining in the remainder of the Eastern range as well as in the Western range. In the southern part of their range, Steller sea lions breed on the island of Ana Nuevo in California, and in southern Oregon at Rogue and Orford Reefs. 
Breeding occurs in June and July and approximately 1500 pups are born annually at the Oregon rookeries (NOAA 2015). Steller sea lions forage and feed on a variety of fish, squid, anchovies, mackerel, rockfish, hake, and sardines and have also been observed feeding on salmonids and sturgeon in the Columbia River system. As with California sea lions that forage for salmon in the Columbia River, there has been an increase in fisheries interactions involving Steller sea lions in recent years.

\section{Changing ocean conditions}

Marine waters off Oregon and southern Washington are part of the California Current System (CCS), a region of major upwelling that varies spatially and temporally (Schwing et al. 1991). These waters are subject to large-scale variations associated with the El Niño Southern Oscillation (ENSO) (Philander 1983). Marine mammal prey species are impacted by upwelling as well as changes in oceanographic conditions such as El Niño, the warm phase of ENSO, that affect their vertical and horizontal distribution and abundance (Brodeur et al. 2006). El Niño is associated with unusually warm water and declines in primary productivity. The presence of El Niño can influence weather patterns, ocean conditions, and marine fisheries across large portions of the globe for an extended period of time (NOAA Climate Prediction center 2016). These anomalous weather patterns affect ocean temperatures and, thus, the Pacific fish stocks that make up the sea lions' diet, as well as impacting many commercially valuable fisheries. Pearcy reported that the 1982-1983 El Niño event saw unprecedented mortality of maturing Coho salmon in populations off Oregon, as well as record lows in sizes of Coho and Chinook salmon 
(Pearcy \& Schoener 1987). Adult Coho salmon returned to hatcheries at smaller sizes, reducing fecundity by an average of $24 \%$ at coastal hatcheries from 1982 to 1983 (Johnson 1988).

Weise found that in offshore California waters during warm water conditions in 2005 which reduced upwelling and primary productivity, male California sea lions shifted foraging behaviors, spending more time further offshore, increasing diving depths an average of $27 \%$ and increasing dive duration by $10 \%$, in response to a depletion of anchovy stocks in nearshore waters (Weise et al. 2006). While the ability to increase dive duration and forage further offshore is a viable life history strategy for California sea lions, variation in prey availability potentially impacts stranding events. For example, in Southern California, strandings of California sea lion pups were elevated between January 2013 and April 2015, to such a degree that the event was declared an Unusual Mortality Event (UME). Findings indicate that a likely contributor to the large number of stranded, malnourished pups was a change in the availability of sea lion prey, especially sardines, a high value food source for lactating females (NOAA Fisheries Protected Resources 2014). The exact mechanism is not yet known, but sardine spawning grounds shifted offshore in 2012 and 2013, and other available prey such as rockfish and market squid may not have provided adequate nutrition for nursing or newly-weaned pups (NOAA Fisheries Protected Resources 2014).

In 2014 and 2015, an unusually warm water mass known as 'the Blob' was observed in the Eastern Pacific, ultimately hugging the coast of North America from Mexico to Alaska, a stretch of over $3200 \mathrm{~km}$. The Blob has three distinct patches, the 
first off the coast of Canada, Washington, Oregon, and California, the second off the coast of Alaska, and a third, smaller patch off Southern California and Mexico (Bond et al. 2015). The phenomenon quelled upwelling that typically delivers nutrients to coastal waters where migratory fish such as salmon and tuna, in addition to marine mammals, consume forage species such as anchovies, sardines, and krill. It is unclear how the northern Pacific ecosystem will respond to this nutrient shortage combined with a strengthening El Niño. Current abundance surveys and stranding reports suggest that yearling and juvenile California sea lions are migrating north, possibly in response to the shift in available prey due to these warm water conditions (NMFS unpublished data 2015, Stranding Network unpublished data 2015).

\section{Spatial and temporal mapping of strandings}

The Marine Mammal Protection Act of 1972 (MMPA) affords all marine mammals, including California sea lions and Steller sea lions, federal protection from "hunting, killing, capture, and/or harassment," except when "takes" are authorized by NOAA (Marine Mammal Commission 2007). Direct and indirect human interactions are sources of California sea lion and Steller sea lion mortality, but the specific ecological and human factors have yet to be quantified for these species.

Geographic Information System (GIS) software enables conservation researchers, planners, and managers to access and utilize spatial information. Large, complex datasets can be statistically queried and analyzed, and the results can be 
displayed in a visually intuitive map format. ESRI ArcGIS software enables users to access publicly available basemaps and display them in the visual map interface ArcMap (Bolstad 2008). Other spatial data can be stored in a geodatabase and added in map layers that can be queried by various attributes and analyzed for patterns or 'hotspots' (Bolstad 2008). Geographic Information Systems have been applied to marine mammal research, but these analyses have primarily focused on species abundance, distribution, and movement. In a Norway study, GIS was used to model energetics simulations of harbor seals co-occurring with fisheries activity in order to gauge the effect of harbor seal predation on gillnet and seine catches (Bjørge et al. 2002). Harris and Gupta utilized National Oceanic and Atmospheric Administration (NOAA) Fisheries stranding records between 1996 and 2002 to create a GIS model of harp seal and hooded seal stranding predictors in the Gulf of Maine (Harris \& Gupta, 2006). In Oregon and Washington, GIS has been used to perform spatiotemporal analysis of a 2007 unusual mortality event (UME) involving harbor porpoises (Norman et al. 2012).

In the Caribbean, GIS is being used to map spatial and temporal dynamics in reef systems, providing valuable information on how to most effectively direct conservation efforts (Maina et al. 2008). In marine environments worldwide, researchers are using GIS as part of the creation of "conservation blueprints" and directing marine spatial planning and research activities (Breman 2002). Hot Spot Analysis and Incremental Spatial Autocorrelation have been applied to identify pollution hotspots in urban soils in Ireland (Zhang et al. 2008), and in analysis of crime, road accidents, and geo-spatial clustering of disease (McCullagh 2006, 
Prasannakumar et al. 2011). In these studies, GIS has proven useful in visualizing and analyzing patterns and hotspots.

\section{Spatial and Statistical Analysis}

In ArcMap, the Hot Spot Analysis tool calculates the Getis-Ord Gi* statistic for data features, resulting in z-scores and p-values that determine the location of clusters of features with high or low values (Getis \& Ord 1996). The tool analyzes each feature within the context of nearby features. In order to be a statistically significant hot spot, a feature must have a high value and be surrounded by other features with high values. The sum of a value associated with a feature and its neighbors is compared proportionally to the sum of all features, and where a difference is too large to be the result of random chance, the result is a statistically significant z-score. False Discovery Rate (FDR) Correction is applied in Hot Spot Analysis as a tool to reduce false-positives due to spatial dependency (Aldstadt 2010). Spatial dependency occurs when features within an analysis are evaluated within the context of nearest neighbors, given that features in close proximity to each other will likely share many of the same neighbors. The FDR correction estimates the number of false-positives likely to occur for a particular confidence level and adjusts the p-value accordingly. Critical p-values are ranked from smallest (strongest) to largest (weakest), and the weakest are assumed to be potential falsepositives and are removed from the list. In order to define the spatial scale of the Hot Spot Analysis and which neighbors are included in the calculation, a distance value must be specified which should relate to the scale of the question (Aldstadt 
2010). The Incremental Spatial Autocorrelation tool calculates spatial autocorrelation for a series of increasing distances. A resulting z-score is returned which indicates the strength of spatial autocorrelation for each distance. Generally, at a certain distance, the z-score peaks, and the first statistically significant peak is often the distance that best reflects the scale of the analysis. In the case of a linear dataset such as strandings that occur on a coastline, it's necessary to eliminate neighboring ocean waters and inland areas from the Hot Spot analysis. Using the Fishnet tool in ArcMap allows the creation of a feature class of rectangular grid cells, $1 \mathrm{~km}^{2}$ and 10 cells wide, containing all of the stranding points. The grid includes the coastline and rivers where strandings occurred, and limits the Hot Spot analysis to these areas. All GIS mapping and analysis was done with ArcGIS version 10.3.

In addition to spatial analysis using GIS, temporal distribution of strandings was preliminarily assessed using Chi-Square Goodness of Fit with a statistical significance level of $p=0.05$. All strandings in the dataset were analyzed by month and species, and further separated by the PSU and HMSC regions, and within region by species, month, year, and cause of death (COD). In the Chi-Square test, numbers of strandings per month were evaluated against the null hypothesis that strandings would be uniformly distributed over all months. The chi-square statistic quantifies how much the observed distribution of stranding counts varies from a hypothesized uniform distribution. As strandings are broken down by region, species, and COD, expected counts per month decrease and the potential for Type 1 error increases. Hence, when expected counts for all months are less than 2.5 , or more than $50 \%$ of months have expected counts of less than five, the power of the test is reduced. 
Therefore, One-Way ANOVA was used to compare means of strandings in each month from year to year to assess whether monthly trends appeared consistent from year to year. Strandings were the Response and each month was the Factor. One-Way ANOVA was also performed to evaluate strandings per month in the presence of commercial fishery activity. Fisheries were represented by a ' 0 ' or ' 1 ' indicating whether that fishery was open during that month, based on publicly available fisheries landing data. To further examine the relationship between strandings and commercial fisheries activity, a Binary Logistic Regression was performed. Strandings were classified as the Response Variable and actual pounds of fish landed (as a proxy for fisheries effort/activity) were the Continuous Predictors. All statistical tests were performed using Minitab 17 software.

\section{Objectives}

The purpose of this research was to analyze California sea lion and Steller sea lion strandings on the Oregon and southern Washington coast in order to address the following research goals:

- Assess spatial and temporal distribution of sea lion strandings, 2006-2014

- Characterize sea lion strandings by cause of death

- Compare distribution of sea lion strandings with environmental factors and anthropogenic activities 
OMMSN Strandings by Order 1989-2016 $n=6358$

\begin{tabular}{lllr} 
& \multicolumn{2}{c}{ Cetaceans } & \multicolumn{2}{c}{ totals } \\
North Coast & 1253 & 294 & 1547 \\
Central Coast & 3151 & 334 & 3485 \\
South Coast & 1180 & 146 & 1326 \\
& & &
\end{tabular}
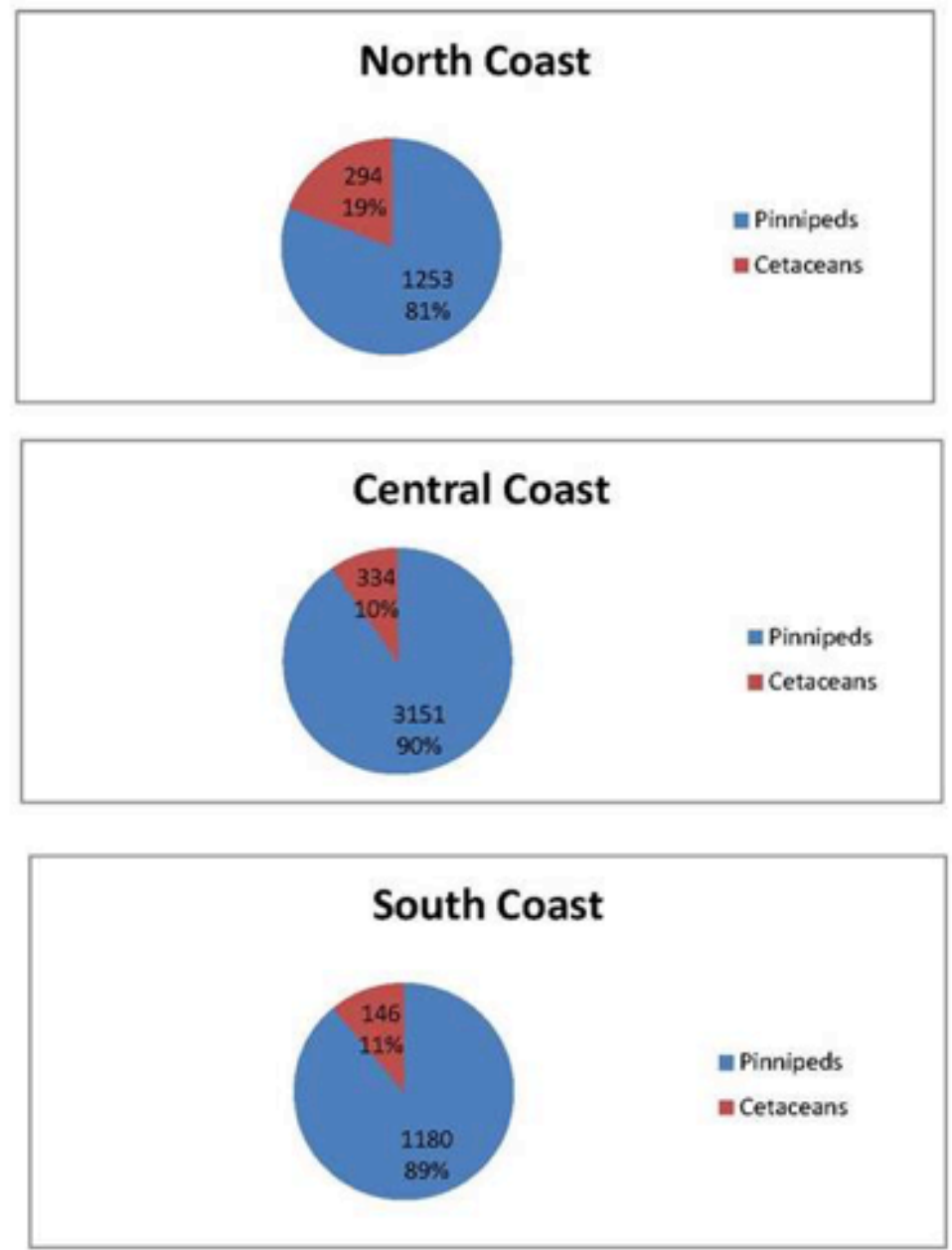

Figure 1.1: Proportion of pinniped and cetacean strandings in Oregon and southern Washington, 1989 to 2016. 


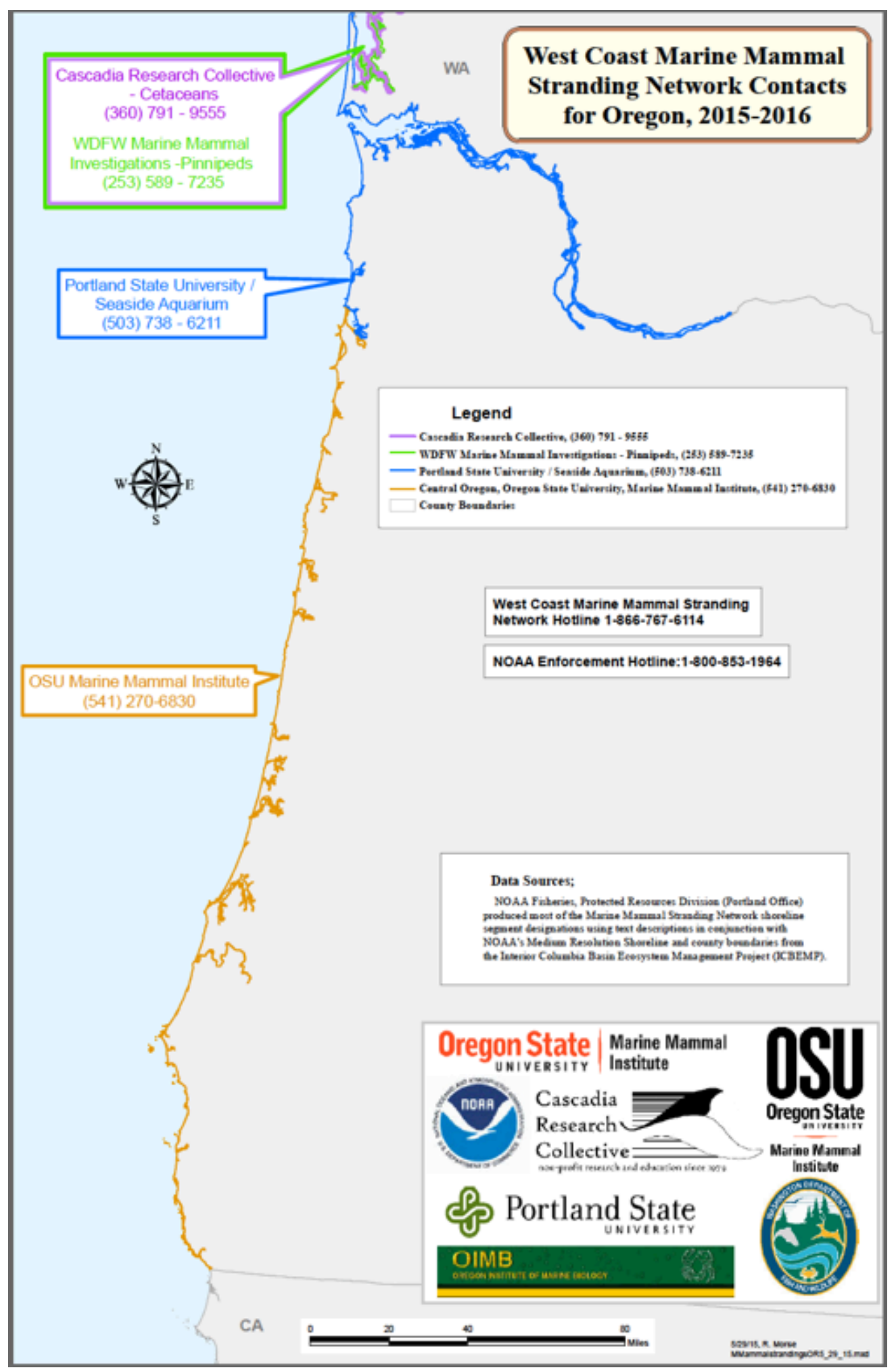

Figure 1.2: Map of Oregon stranding network regions. 


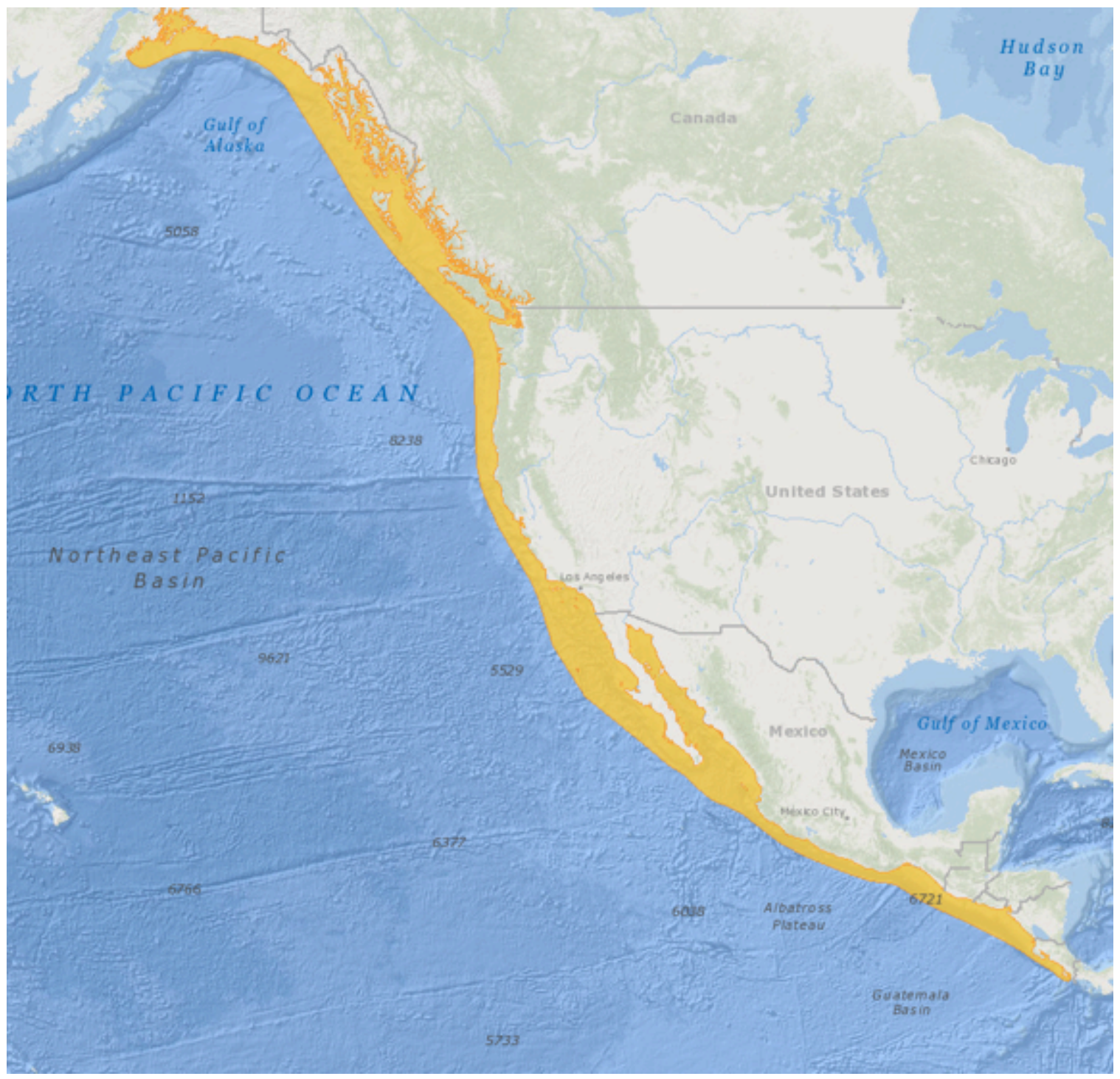

Figure 1.3: California sea lion geographic range shown in yellow (IUCN Redlist). 


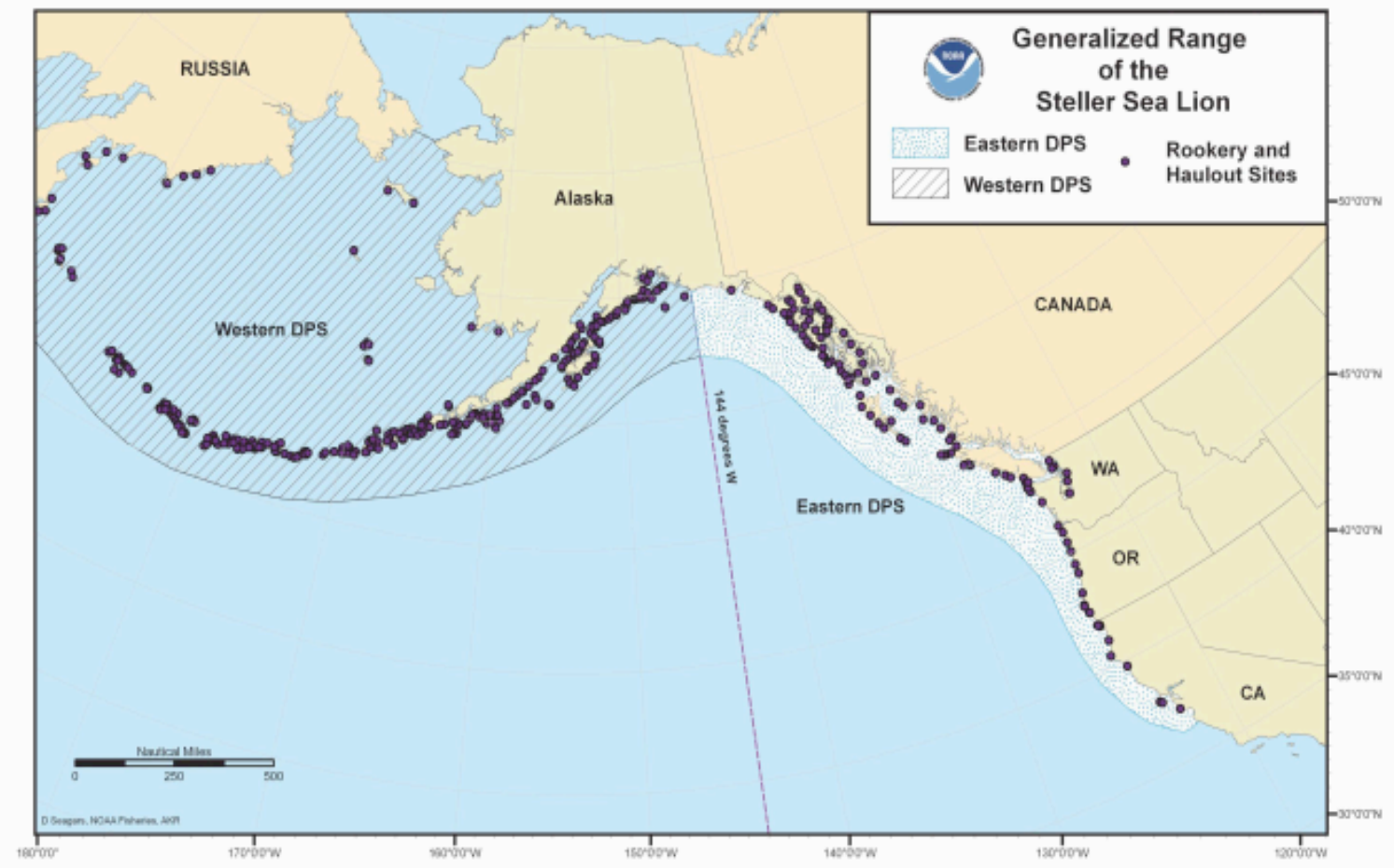

Figure 1.4: Steller sea lion geographic range (NOAA Fisheries). 


\section{Chapter 2: Assessing spatial and temporal distributions of sea lion strandings in Oregon and southern Washington, 2006-2014}

\section{Introduction}

Stranding networks were established around the coastal United States in 1992 as a follow-up action to the Marine Mammal Protection Act of 1972 (Geraci \& Lounsbury 2005). Data collection is standardized and reported to the national database in accordance with established protocols (Carretta et al. 2009). Stranding networks respond as personnel, resources, and geographic conditions allow. Reports of strandings are opportunistic, often made by members of the public and by local and state agencies. When responding to a stranding, location and basic biological information is recorded (species, life stage, sex, state of decomposition, and external measurements are taken). Depending on resources, a necropsy is performed to assess morphological indicators of body condition, illness, or injury. Information is compiled regarding what species of animals stranded and in what numbers in a given year, but deeper analysis is required in order to assess possible spatial and temporal trends. In order to address these questions, sea lion strandings from 2006 to 2014 were analyzed by year and month, including spatial analysis in ArcMap version 10.3 as well as temporal analysis using Minitab 17. 


\section{Methods}

Oregon and southern Washington stranding records of all California and Steller sea lions from 2006 through 2014 were reviewed and analyzed by year, month, species, region (PSU and HMSC), sex and age class. Chi-Square Goodness of Fit was performed on each year as a preliminary means of examining whether strandings were normally distributed. One Way Analysis of Variance (ANOVA) was performed using each month as a variable, by region and by species, with stranding counts as the Response and month as the Factor.

For spatial analysis, stranding data was imported into ArcMap as tabular data, converted to shapefiles and projected (NAD83 projection). Conversion of the strandings into shapefiles allowed the data to be queried by date, species, and stranding region. Coastal and shoreline features were mapped using publicly available digital data sets.

The data was displayed by individual year, by species, by month. The linear nature of a dataset in which all points are along a coastline, estuary, or river presented a challenge in performing spatial analysis because it limits the number of neighbors that can be used in calculations. To address this, a fishnet (Fig. 2.1) was created in ArcMap consisting of $1 \mathrm{~km}^{2}$ cells in a grid $10 \mathrm{~km}$ wide along the entire coast of Oregon, and Washington's Long Beach Peninsula and up the Columbia River, all part of the stranding response area. All strandings were included in the cells. Because strandings occur along the coastline and occasionally up coastal rivers, the grid cells that extended on land and out into the ocean constituted spatial "noise" in the data and needed to be removed. The rivers in which strandings occurred were 
added to the grid in order to include those strandings without making the entire grid extend over $10 \mathrm{~km}$ inland. The strandings were then joined to the grid using the Spatial Join tool, creating a new grid containing all stranding points within its cells. Incremental Spatial Autocorrelation was performed in order to establish the appropriate distance for the Hot Spot Analysis. The Incremental Spatial Autocorrelation tool calculates a spatial autocorrelation for a set of increasing distances, generating a z-score which indicates the strength of autocorrelation for each distance. At a certain distance, the z-score peaks, and the first statistically significant peak is often the distance that best reflects the scale of the analysis. Because the grid cells were each $1 \mathrm{~km}^{2}$, initial distance band was set to 1000 meters, with increments of 100 meters in 10 bands. In the resulting graph, the first peak occurred at 1600 meters (Fig. 2.2). This assumes that strandings within 1600 meters of each other may be associated, a reasonable assumption given that this is generally within the distance of an expanse of beach on the Oregon and southern Washington coast, and is the value that was used in the Distance Band Threshold field of the Hot Spot Analysis. Hot Spot Analysis was performed for all strandings in the data set, and by species.

\section{Results}

Over the nine years of study (2006-2014), 1532 California and Steller sea lions stranded in Oregon and southern Washington. California sea lions accounted for 1023 strandings (67\%) and Steller sea lions accounted for 509 (33\%). The greatest number of strandings occurred in 2009 and 2010 (Fig. 2.3), with the 
greatest overall number of strandings occurring in September, October, and November (Fig. 2.4). One-way ANOVA showed strandings (both species, both regions) were significantly high $(\mathrm{p}<0.05)$ in September $(\mathrm{p}=0.0001)$, October $(p=0.0066)$ and November $(p=0.0196)$. The highest number of Steller sea lions strandings occurred in July and August, while California sea lions stranded in the largest numbers in September, October, and November (Fig. 2.5). These trends were consistent from year to year.

In the PSU stranding network region, there were 445 strandings in the study period, 149 Steller sea lions (33\%) and 296 California sea lions (67\%, Fig. 2.6). In the PSU region, Steller sea lions stranded with the greatest frequency in May and June (Chi-square Goodness of Fit: $p=0.0035$, Fig. 2.7), California sea lions in September, October, and November, but also in May and June (Chi-square Goodness of Fit: $\mathrm{p}<0.0001$, Fig. 2.8). One-way ANOVA was conducted to determine whether PSU stranding fluctuations correlated with any individual month. There was a statistically significant correlation between all PSU strandings and September as determined by one-way ANOVA, $[F(8,99)=3.35, \mathrm{p}=0.002]$. Although October and November remained high, they were not statistically significant.

In the HMSC stranding network region, there were 1087 strandings in the study period, 360 Steller sea lions (33\%), and 727 California sea lions (67\%, Fig. 2.9). In the HMSC region, Steller sea lion strandings were most frequent in July and August (Chi-square Goodness of Fit: p $<0.0001$, Fig. 2.10), California sea lion frequency was highest in September, October, and November (Chi-square Goodness of Fit: $\mathrm{p}<0.0001$, Fig. 2.11). 
Because female California sea lions don't migrate north to Oregon, the 1023 California sea lions in the study period were almost exclusively adult and subadult males, although there was a substantial increase in strandings of yearlings in 2009 and 2010. All strandings rose proportionally during the same two years, but the presence of a large number of yearlings may indicate a shift in migratory behavior of these younger animals for those years (Fig. 2.12).

Of the Steller sea lions in the study period, 200 were female, 184 male, 125 unknown. The majority of Stellers were adult, with pups comprising the second largest proportion due to an increase in July of 2007 (Fig. 2.13). Steller sea lion adults were highest in 2009, consistent with strandings of both species, and pups were highest in 2007, peaking in July of that year.

Hotspot analysis clearly indicates higher density of strandings in proximity to the major coastal estuaries, specifically the mouth of the Columbia River, Tillamook Bay, Yaquina Bay, and Coos Bay (Fig. 2.14).

\section{Discussion}

From 2006 to 2014, approximately twice as many California sea lions as Steller sea lions stranded in Oregon and southern Washington, and twice as many sea lions of both species stranded in the HMSC network (central and southern Oregon) than in the PSU network (northern Oregon and southern Washington). Strandings peaked in September, October, and November. When strandings are analyzed separately by species, Steller sea lion strandings peaked in June and July, and California sea lions peaked in September, October, and November. These 
temporal differences are consistent with the different life histories of the two species. Steller sea lions are congregating in large numbers at Oregon rookeries during the summer months, hence the presence of both adult and pup mortality during those months. At the same time, in June and July, California sea lions have migrated south to the Channel Islands in California, to return in large numbers in September. As a result, no pup mortality is seen in Oregon among California sea lions, but adult and subadault mortality is consistently the highest, with increase in yearling mortality during particular years, in this case 2009 and 2010.

Geographically, strandings occur over most of the Oregon coast, with clear hotspots around the mouth of the Columbia River, Tillamook Bay, Yaquina Bay, and Coos Bay. These estuaries are also home to population centers-Astoria, Tillamook, Newport, and Coos Bay-- and Oregon's largest commercial fishing fleets. While population density increases the likelihood of a stranded animal being reported, proximity to these fishing centers also increases the likelihood of fisheries interactions. These interactions may be a result of large numbers of sea lions aggregating in productive estuaries where there is also a large fishing fleet presence, including fish cleaning stations at marinas which may attract sea lions. 


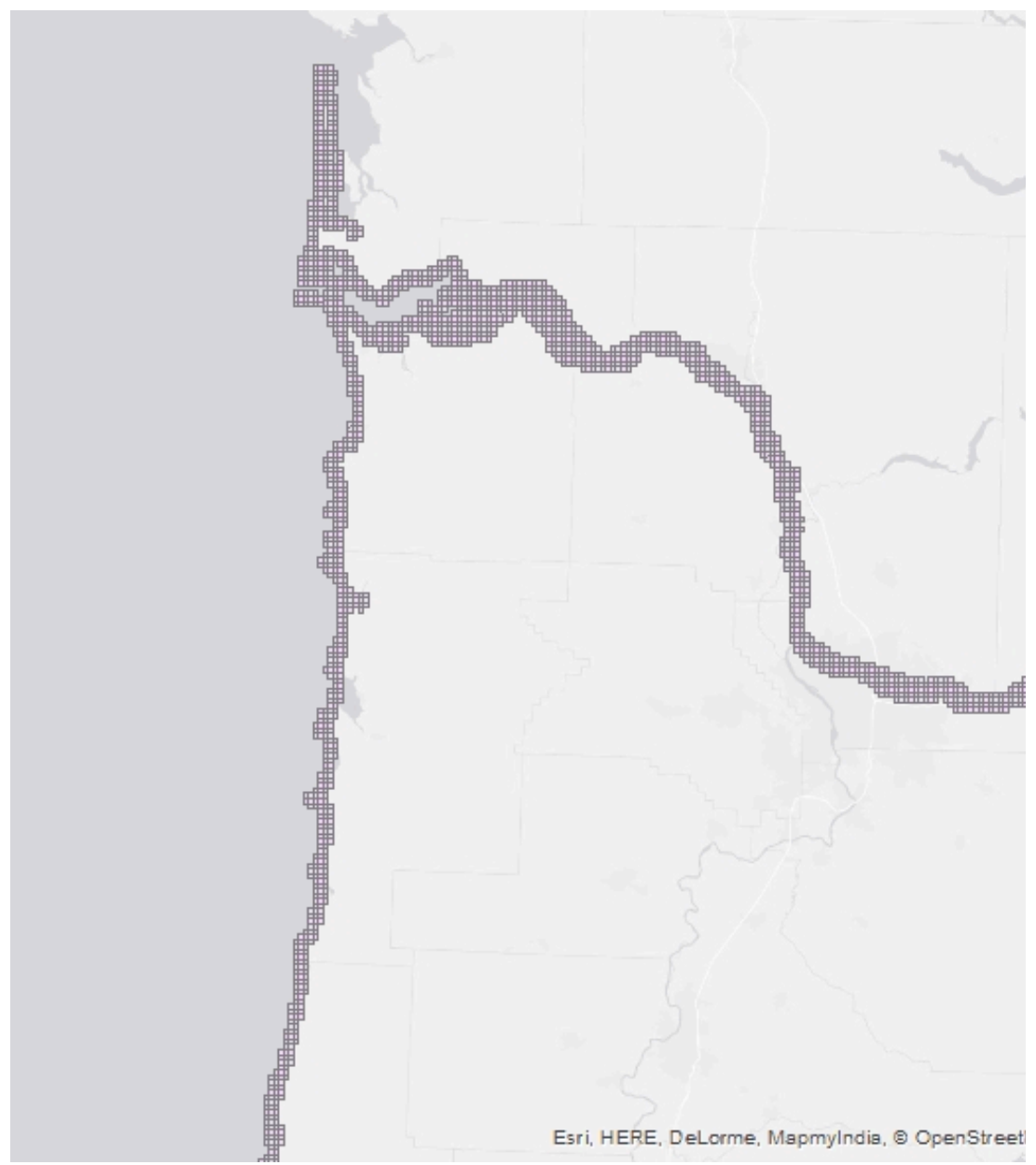

Figure 2.1: Fishnet grid of $1 \mathrm{~km}^{2}$ grid cells. Grid is $10 \mathrm{~km}$ wide, capturing all strandings in the study period within the cells. Spatial join was performed to join stranding points to grid cells, giving each cell a value based on the number of strandings within it. 


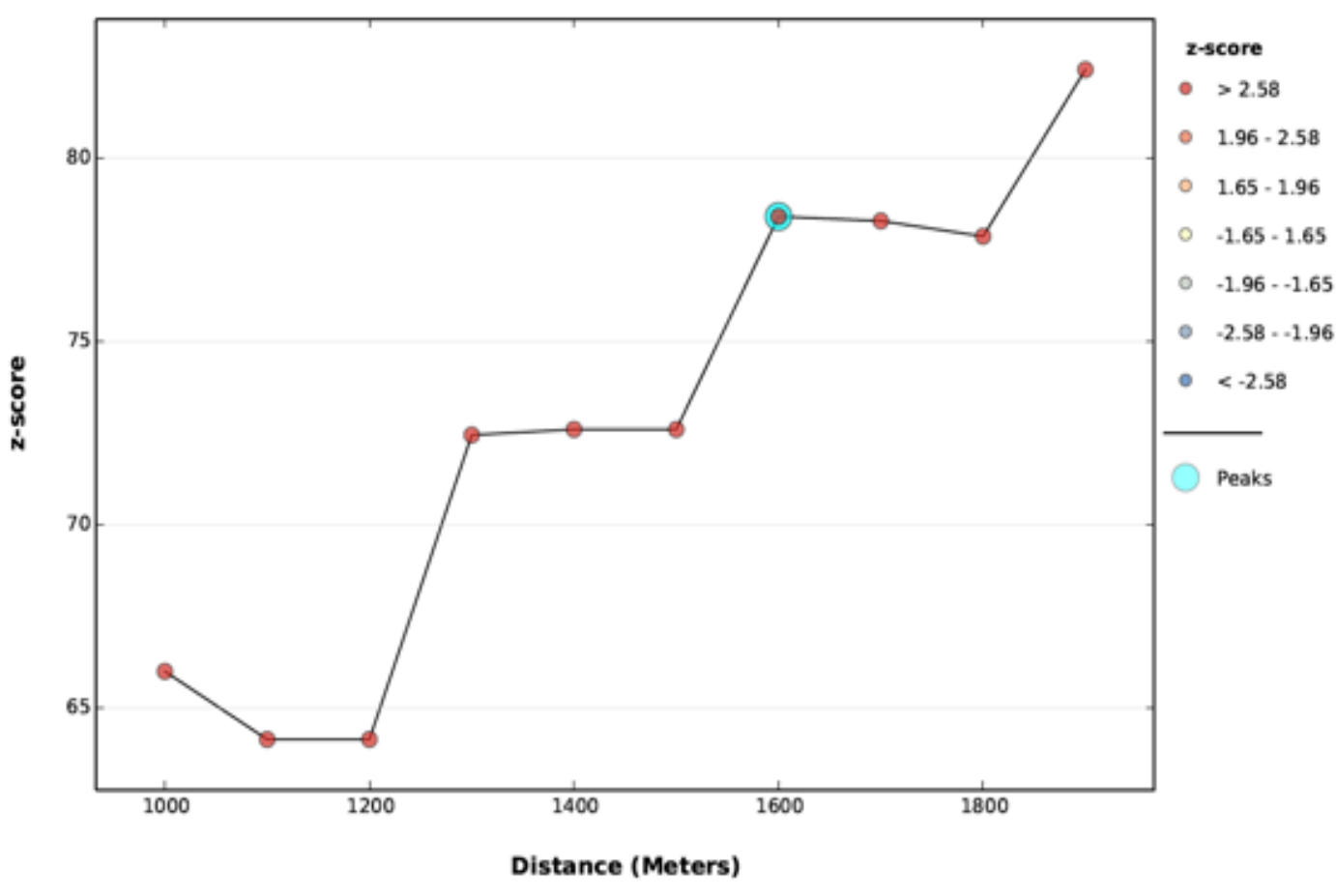

Figure 2.2: Incremental Spatial Autocorrelation for all sea lion strandings, 2006-2014, based on $1 \mathrm{~km}^{2}$ grid cells containing all stranding points. Initial distance band was set to $1000 \mathrm{~m}$ with increments of $100 \mathrm{~m}$ in 10 bands. The Incremental Spatial Autocorrelation tool calculates spatial autocorrelation for a set of increasing distances. A resulting z-score is returned which indicates the strength of spatial autocorrelation for each distance. The first significant peak is often the distance that best reflects the scale of the analysis. The peak at $1600 \mathrm{~m}$ indicates this is the appropriate distance for the Distance Band Threshold field in the Hot Spot Analysis test. (ArcMap version 10.3) 
Oregon and southern Washington sea lion strandings

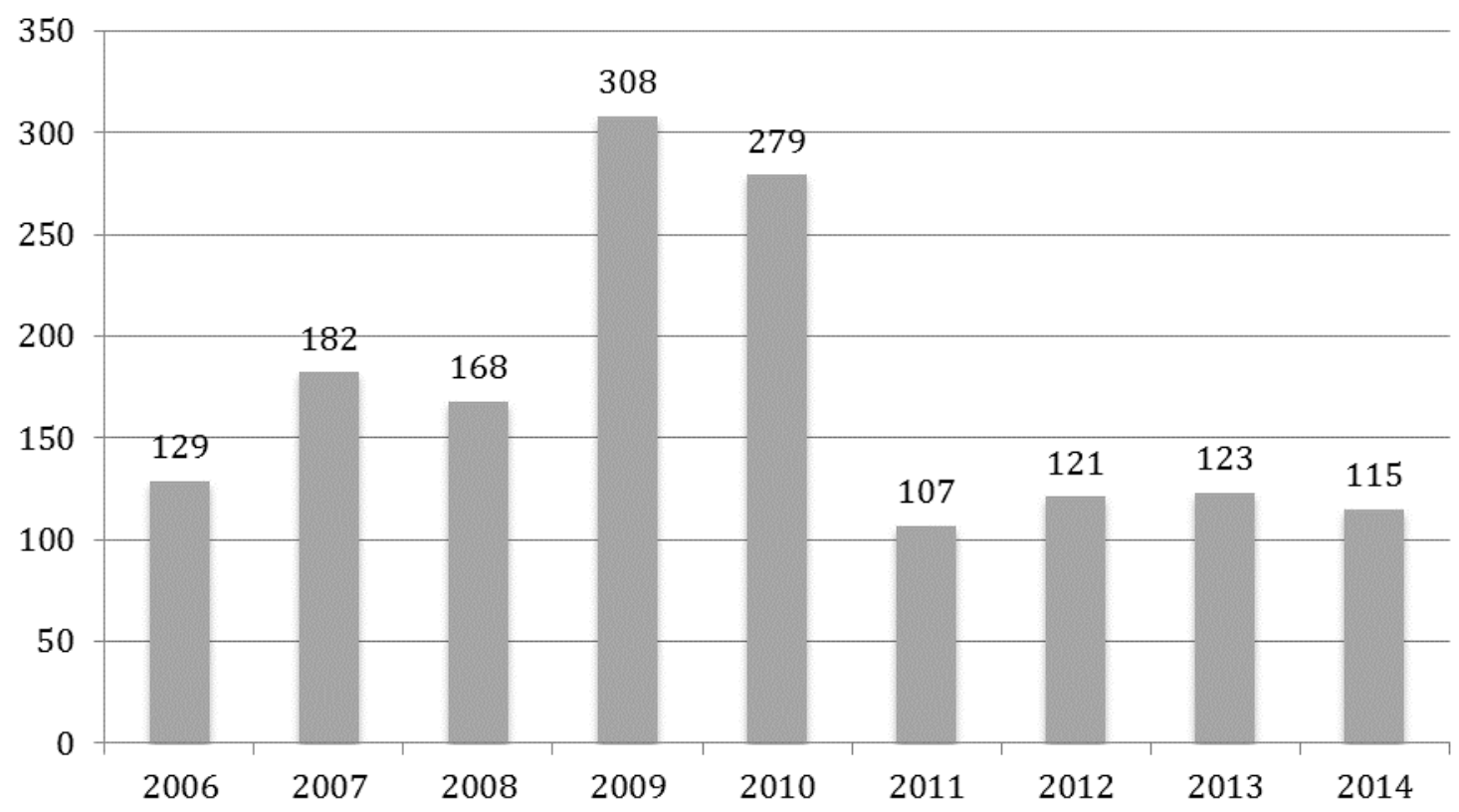

Figure 2.3: California and Steller sea lion strandings in Oregon and southern Washington, 2006-2014, by year.

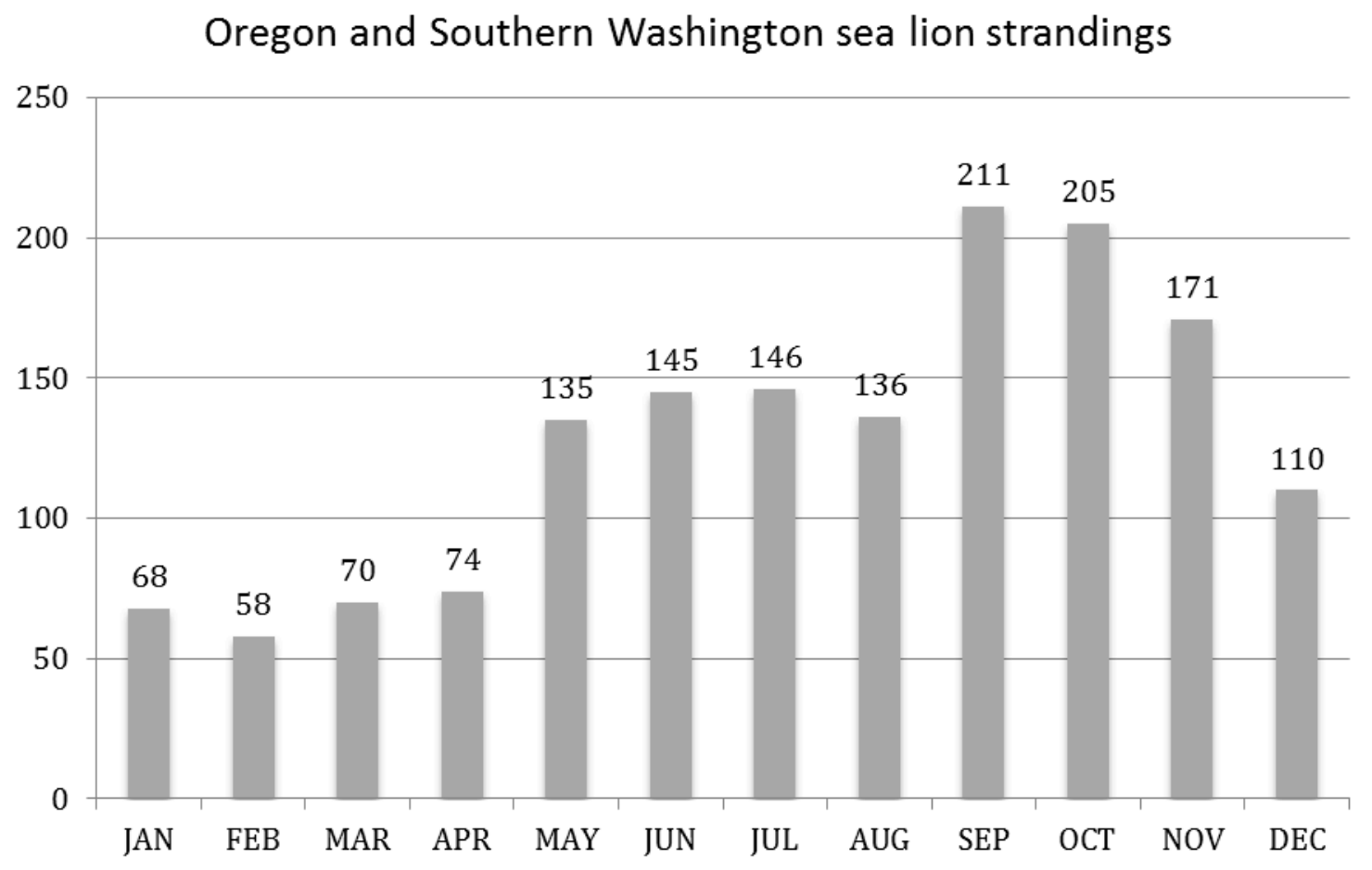

Figure 2.4: California and Steller sea lion strandings in Oregon and southern Washington, 2006-2014, by month. 


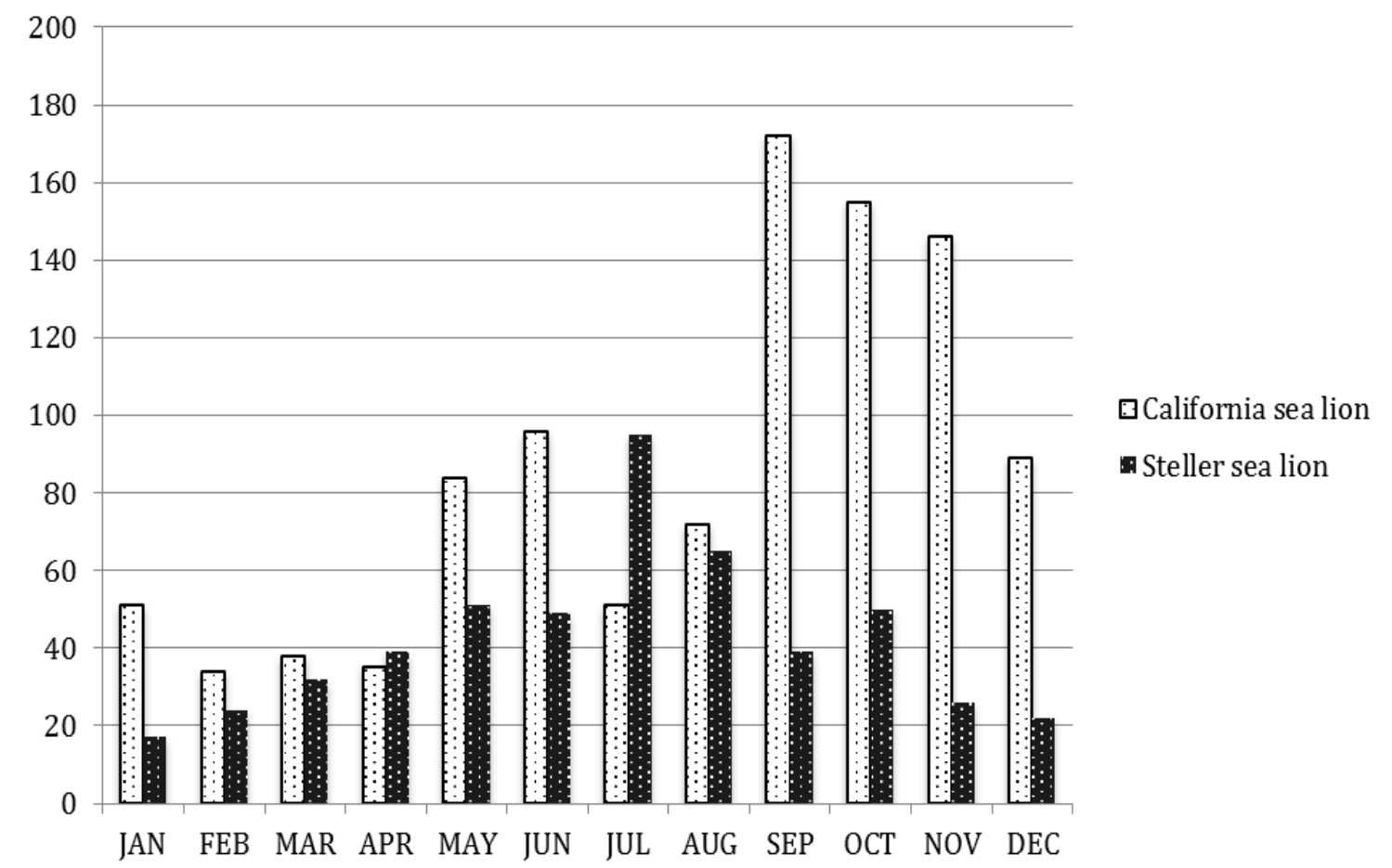

Figure 2.5: California and Steller sea lion strandings, 2006-2014, by species.

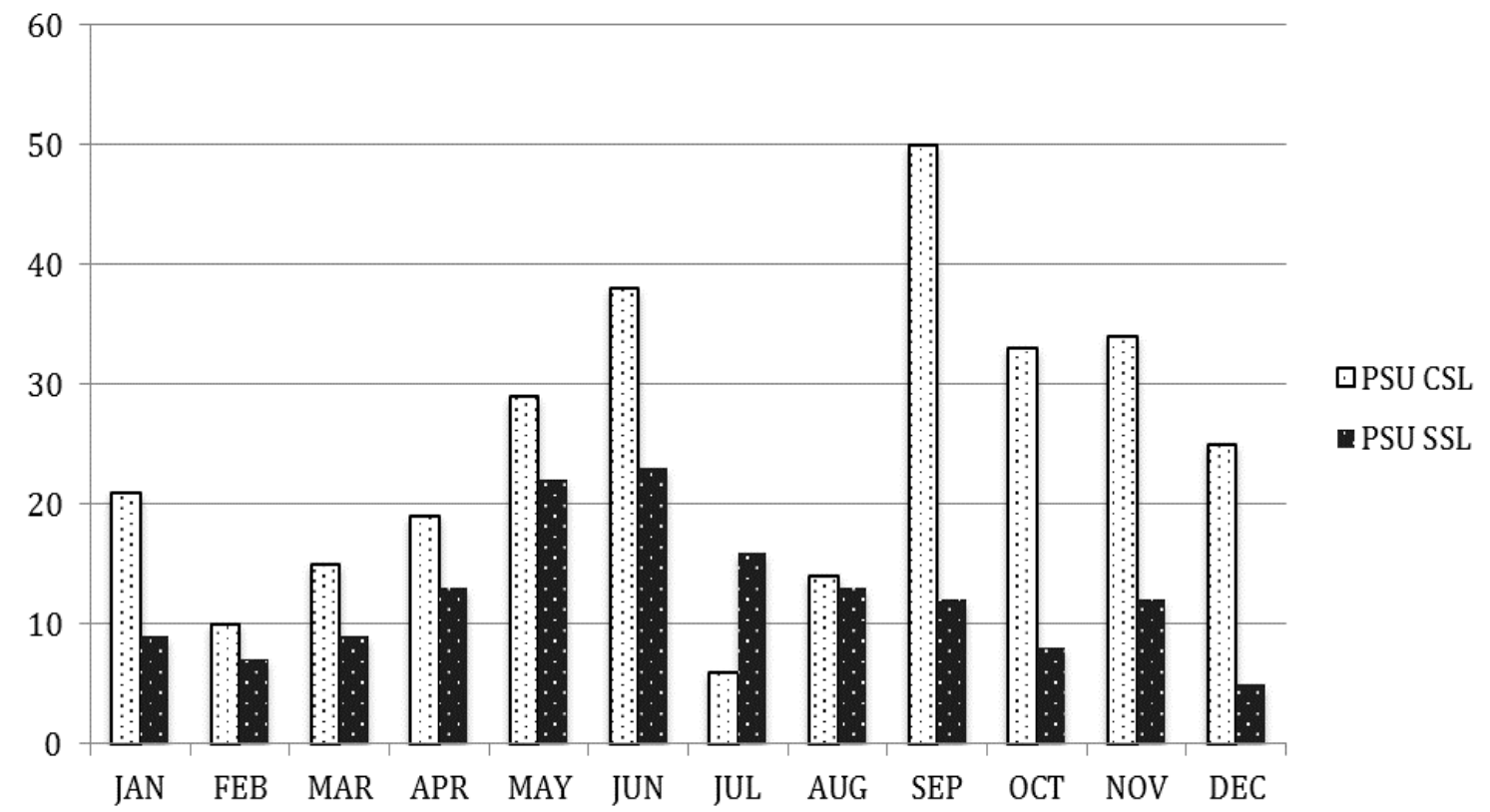

Figure2.6: PSU California (CSL) and Steller sea lion (SSL) strandings, 2006-2014, by species. 


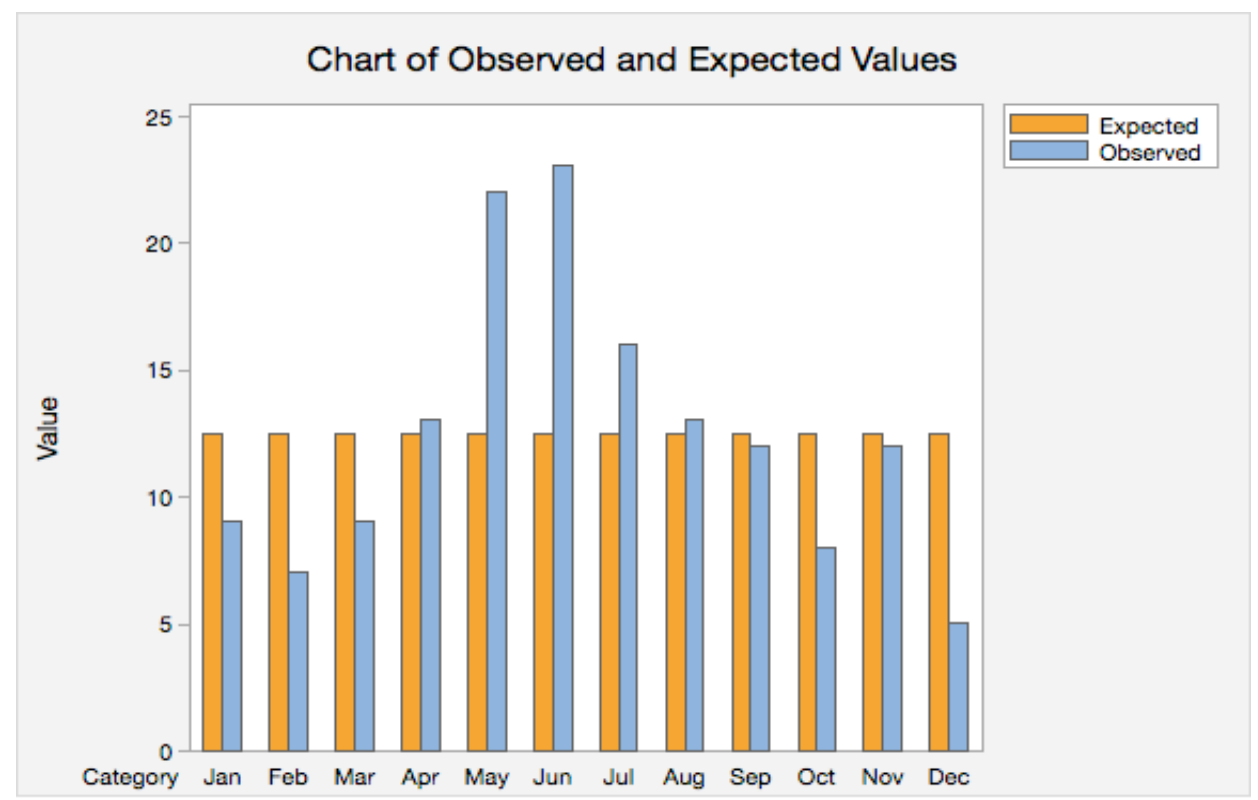

Figure2.7: Chi-square Goodness of Fit test for PSU Steller sea lions, 2006-2014, n=149, p0.0035 .

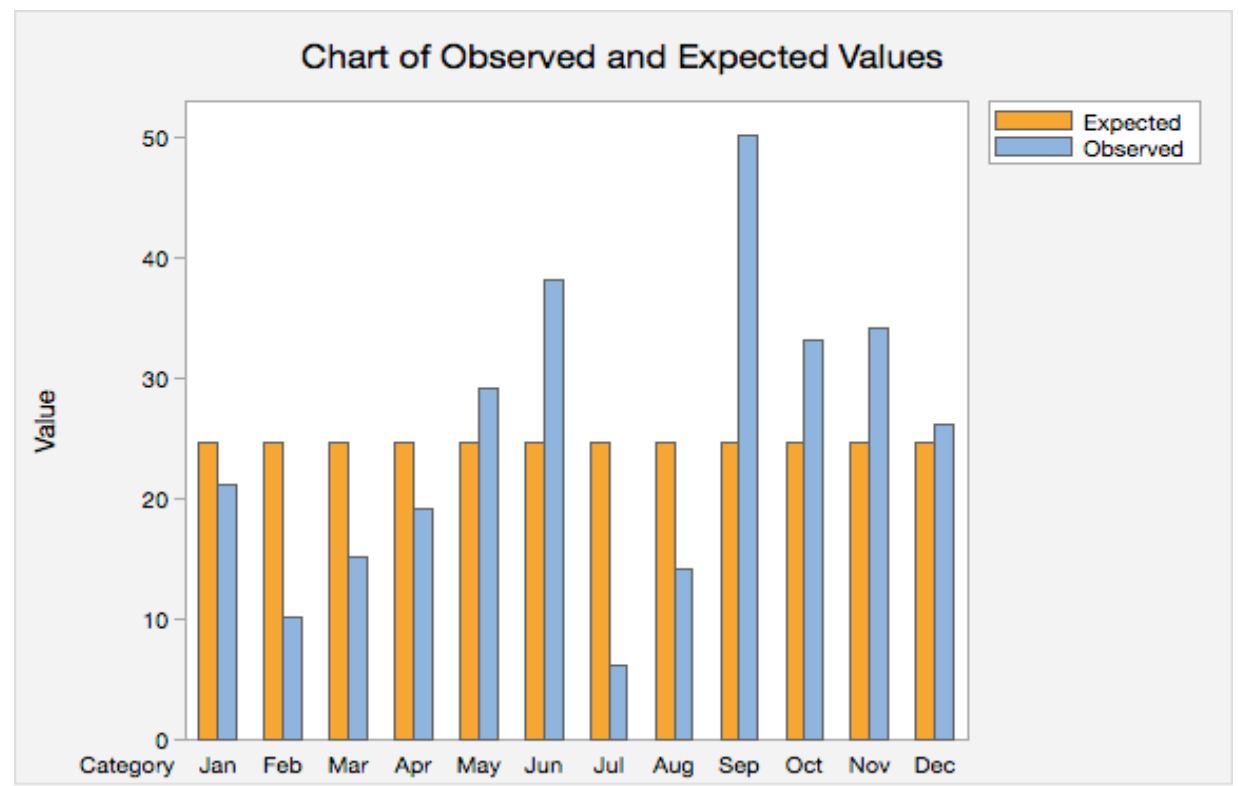

Figure2.8: Chi-square Goodness of Fit test for PSU California sea lions, 2006-2014, n=295, $\mathbf{p}<0.0001$. 


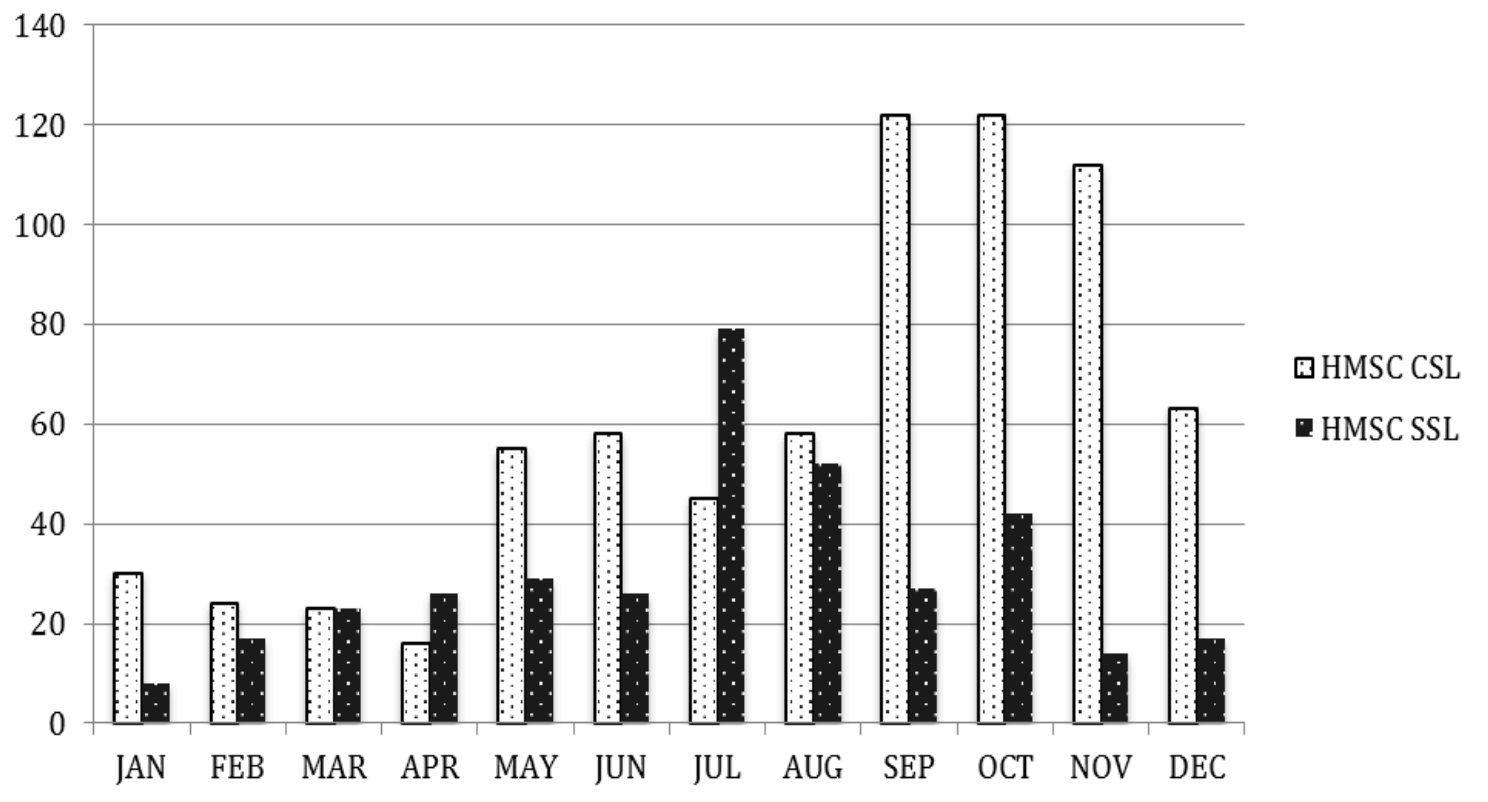

Figure 2.9: HMSC California (CSL) and Steller sea lions (SSL), 2006-2014, by species. 


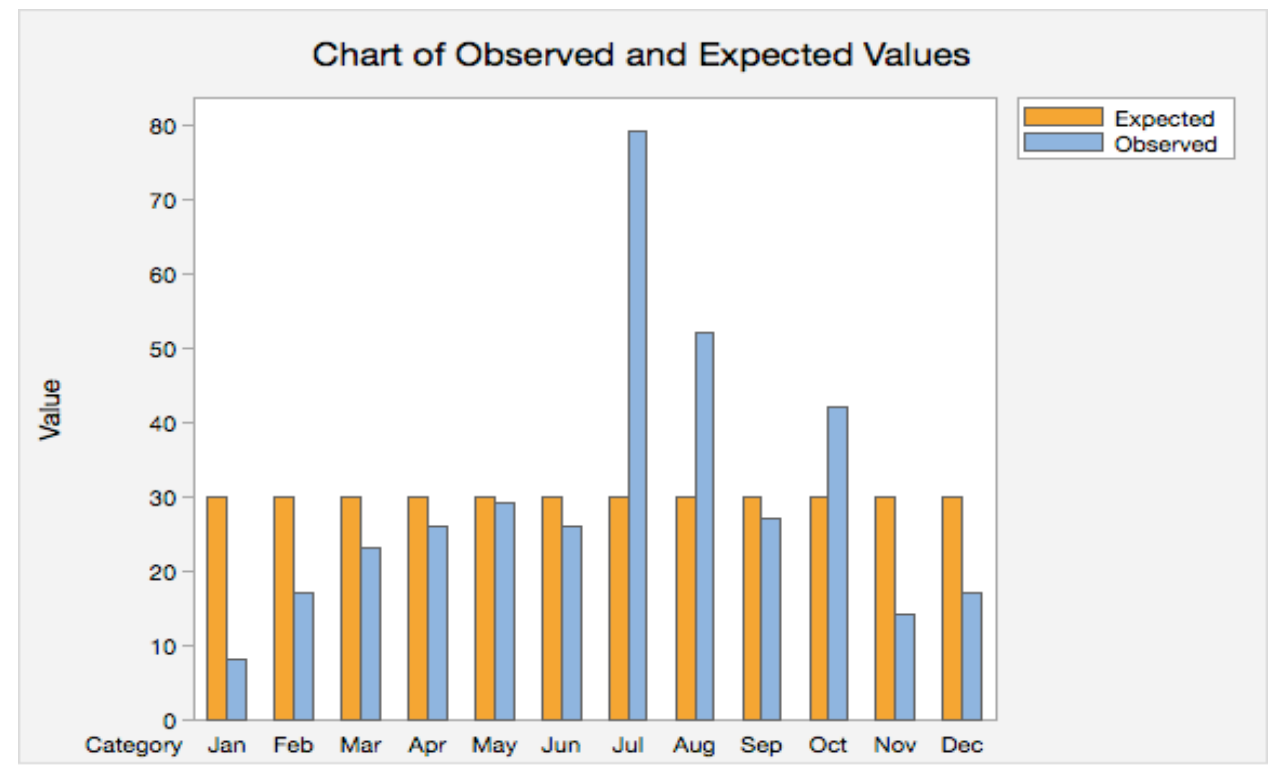

Figure 2.10: Chi-Square Goodness of Fit test for HMSC Steller sea lions, 2006-2014, $n=360$, $\mathbf{p}<\mathbf{0 . 0 0 0 1}$.

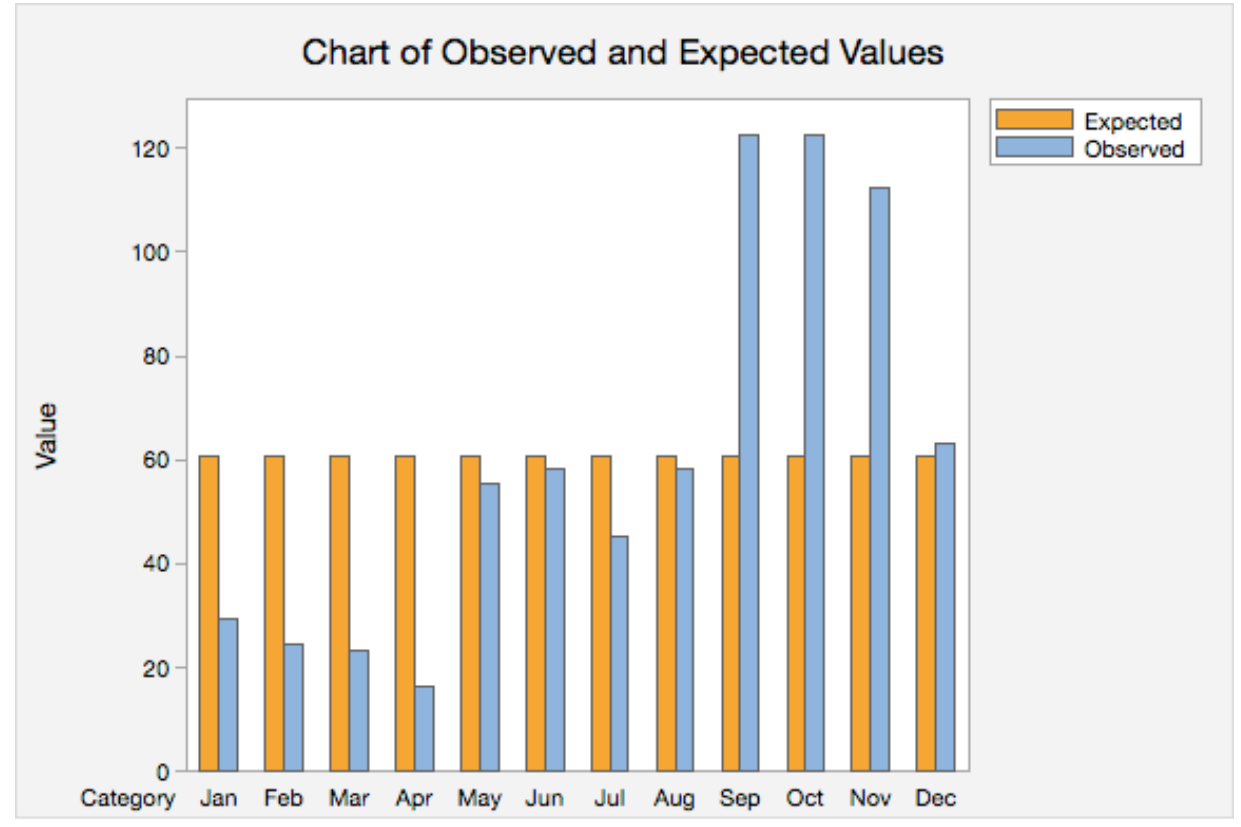

Figure 2.11: Chi-Square Goodness of Fit test for HMSC California sea lions, 2006-2014, n=727, $\mathbf{p}<0.0001$. 


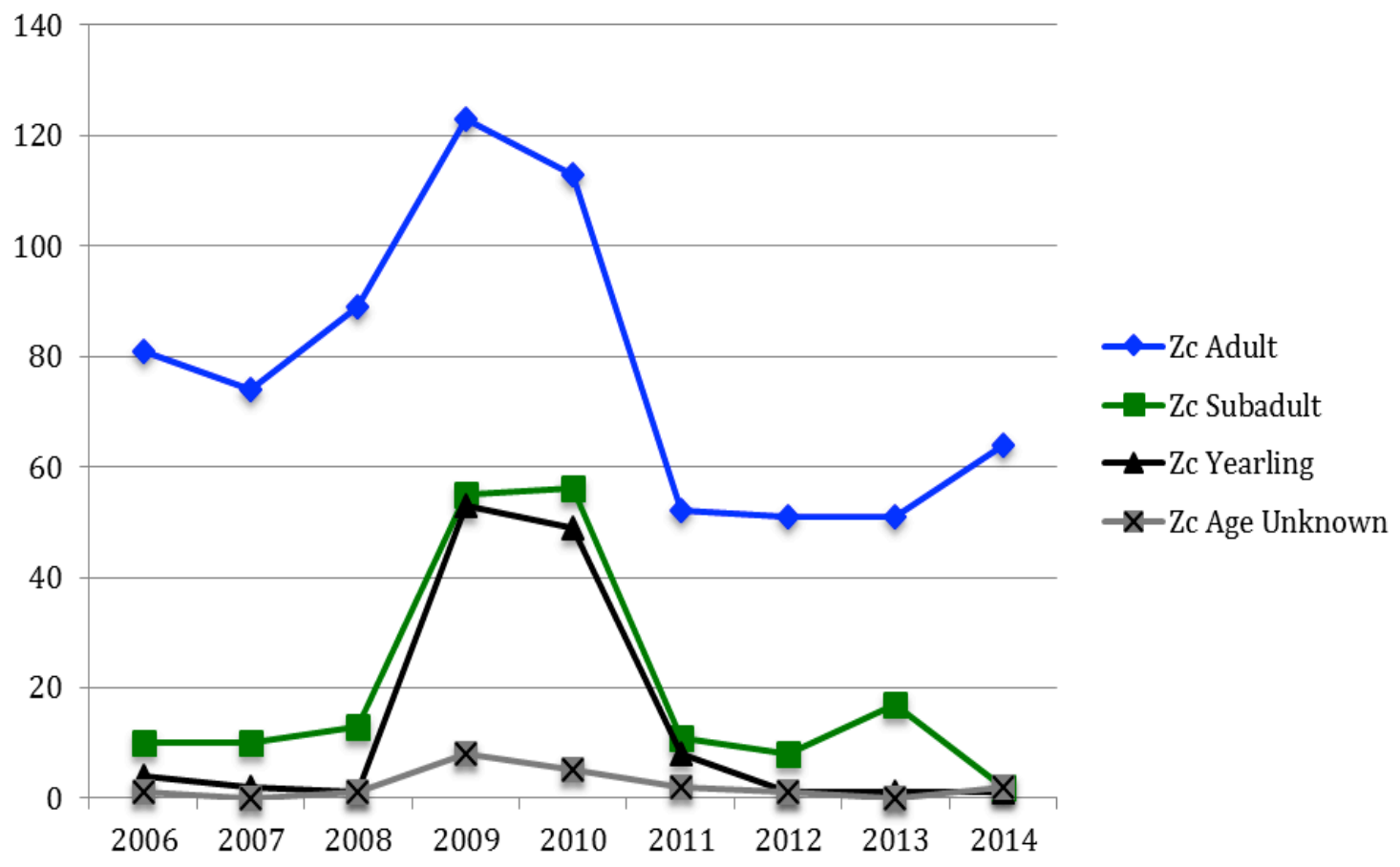

Figure 2.12: California sea lion strandings, 2006-2014, by age class.

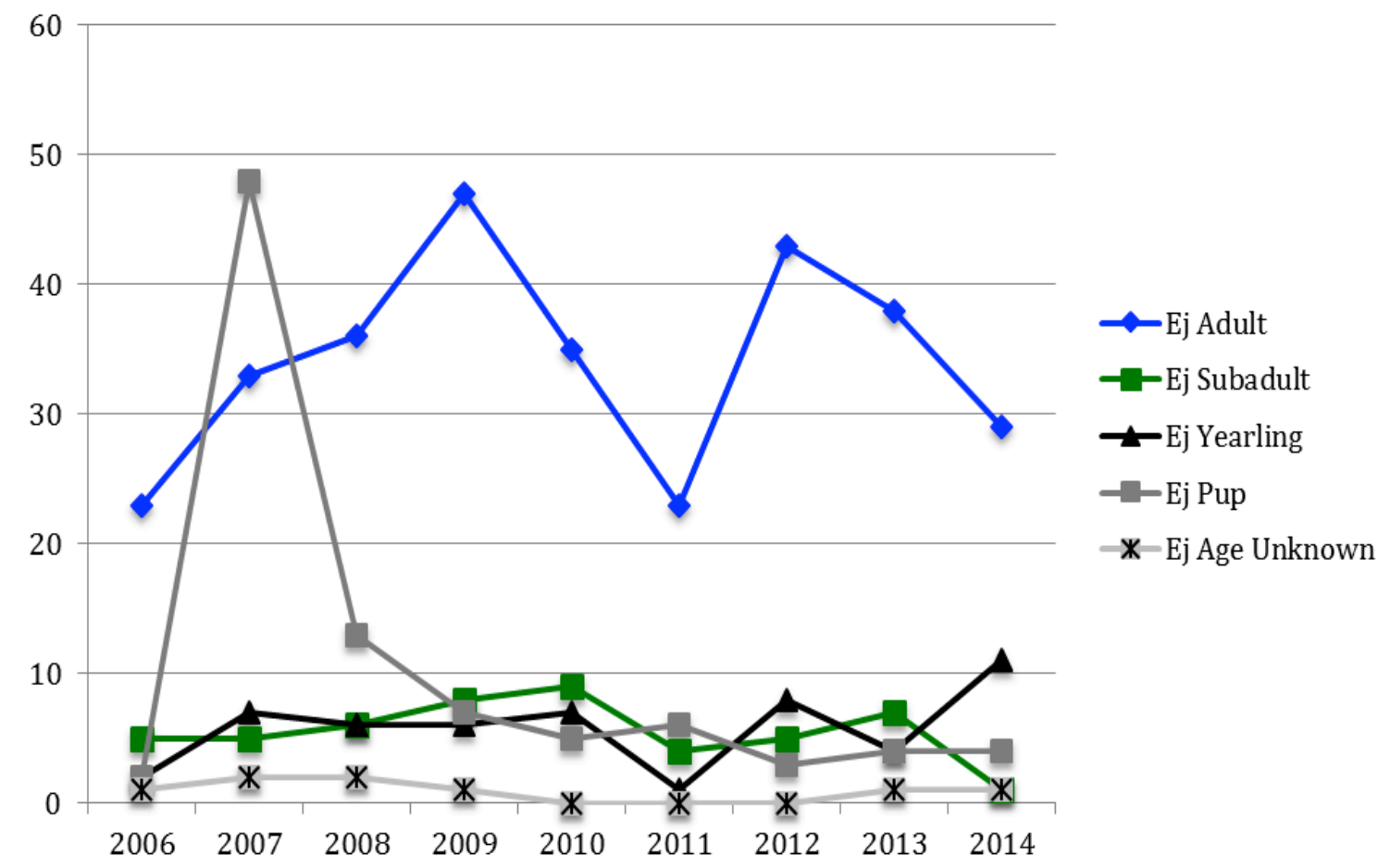

Figure 2.13: Steller sea lion strandings, 2006-2014, by age class. 

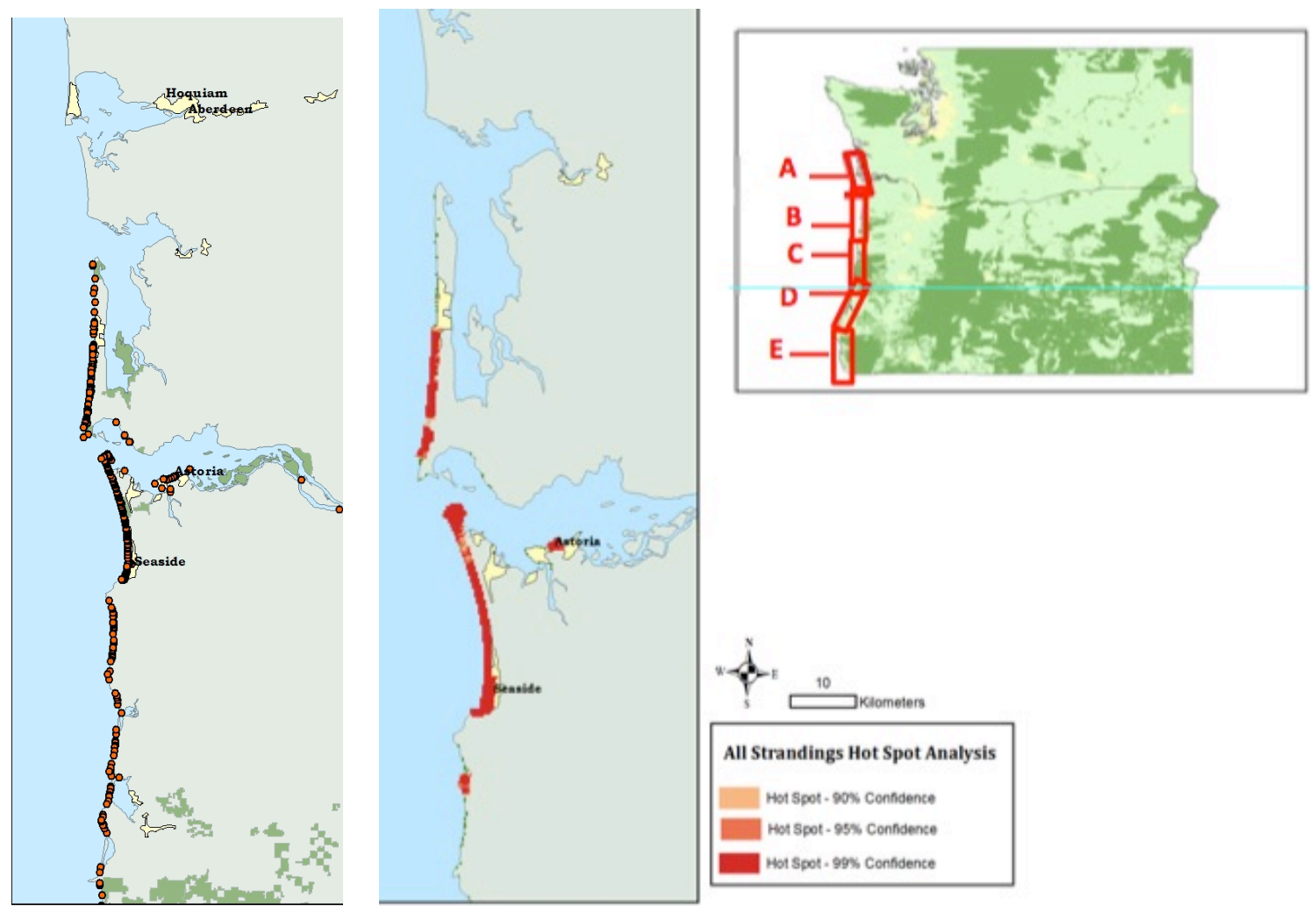

A. All sea lion strandings (left) and results of Hot Spot Analysis (right), 2006-2014; Long Beach Peninsula, Washington to northernmost Oregon coast
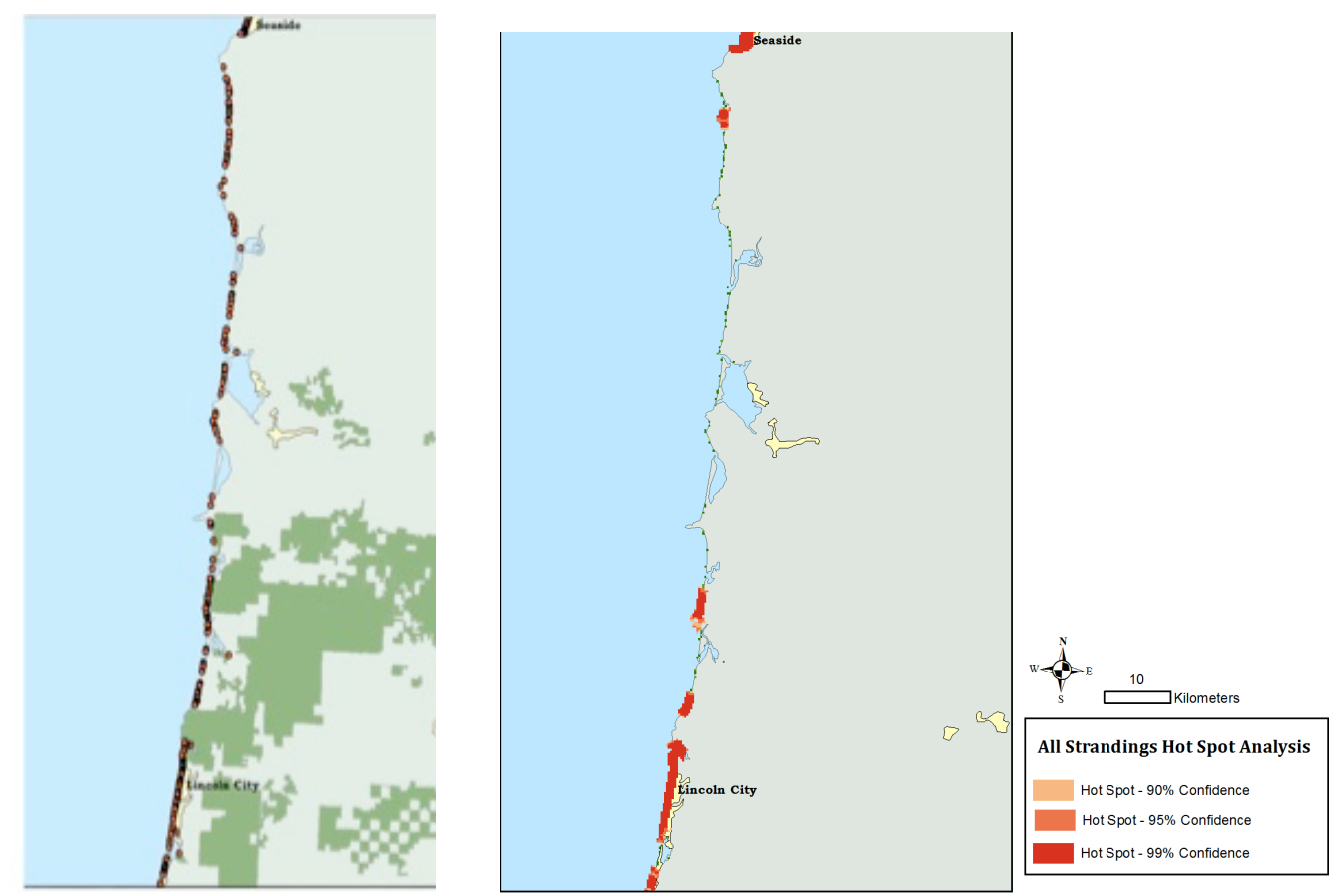

B. All sea lion strandings (left) and results of Hot Spot Analysis (right), 20016-2014, Seaside to south of Lincoln City 

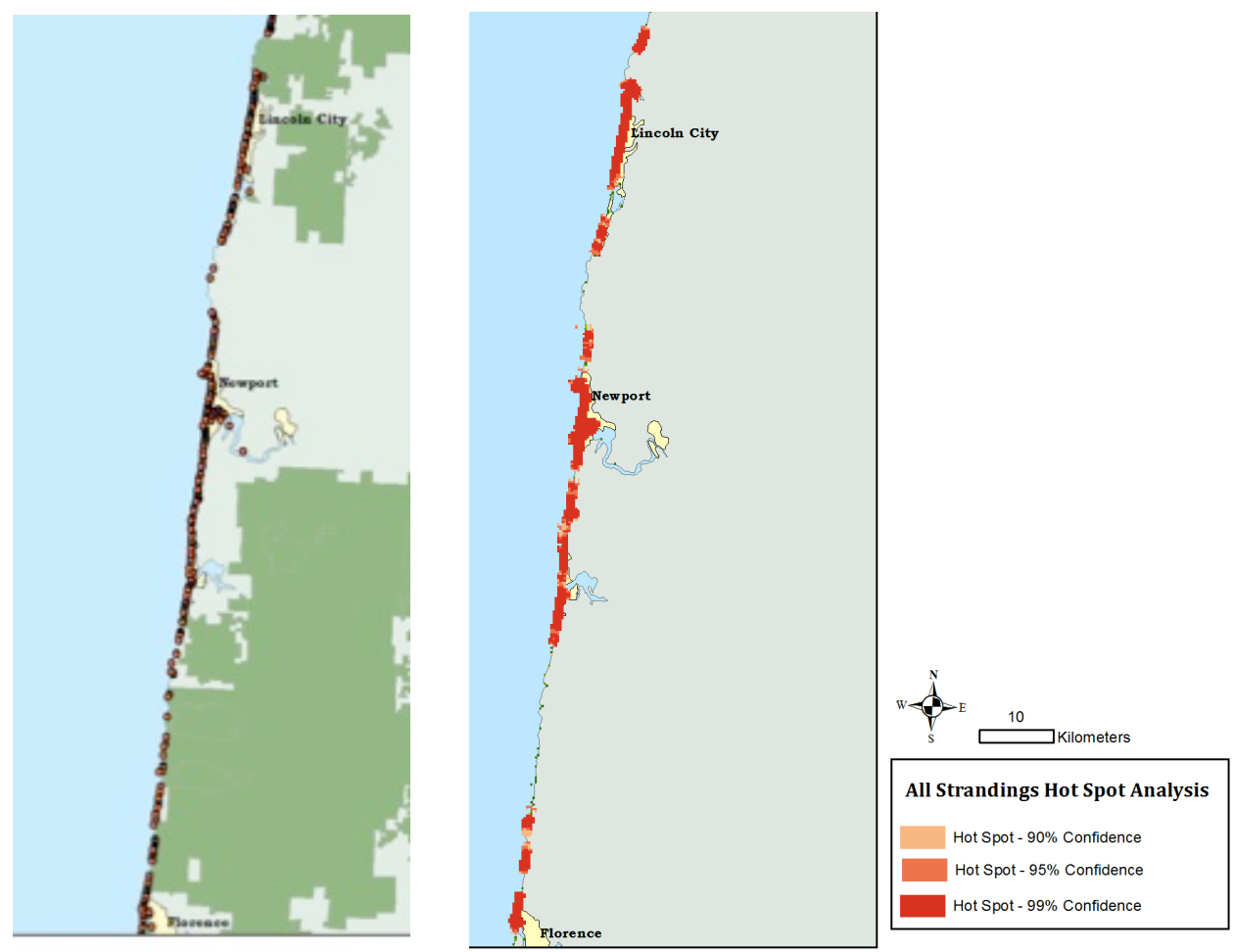

C. All sea lion strandings (left) and results of Hot Spot Analysis (right), 2006-2014, Lincoln City to Florence
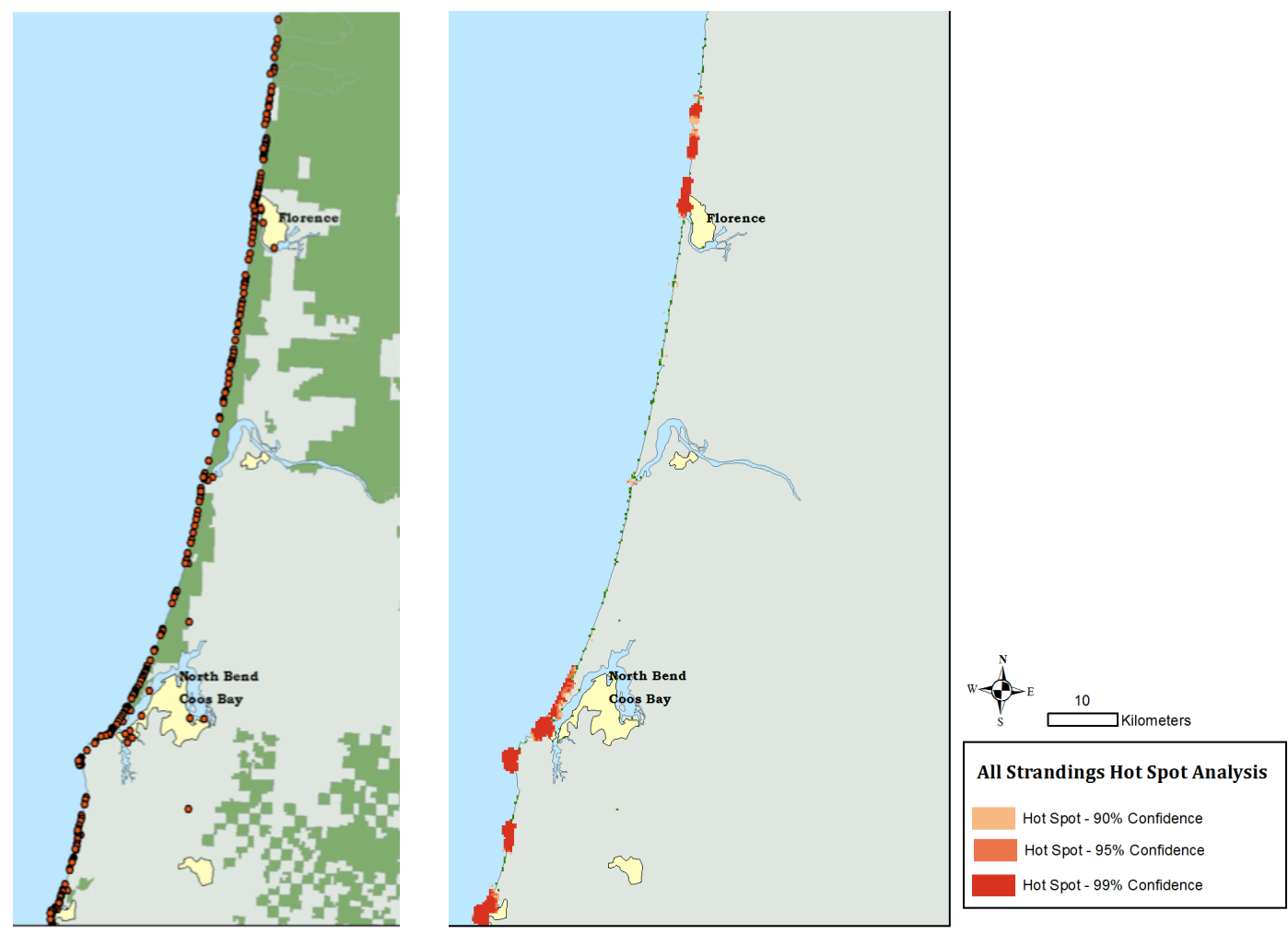

D. All sea lion strandings (left) and results of Hot Spot Analysis (right), 2006-2014, Florence to south of Coos Bay 

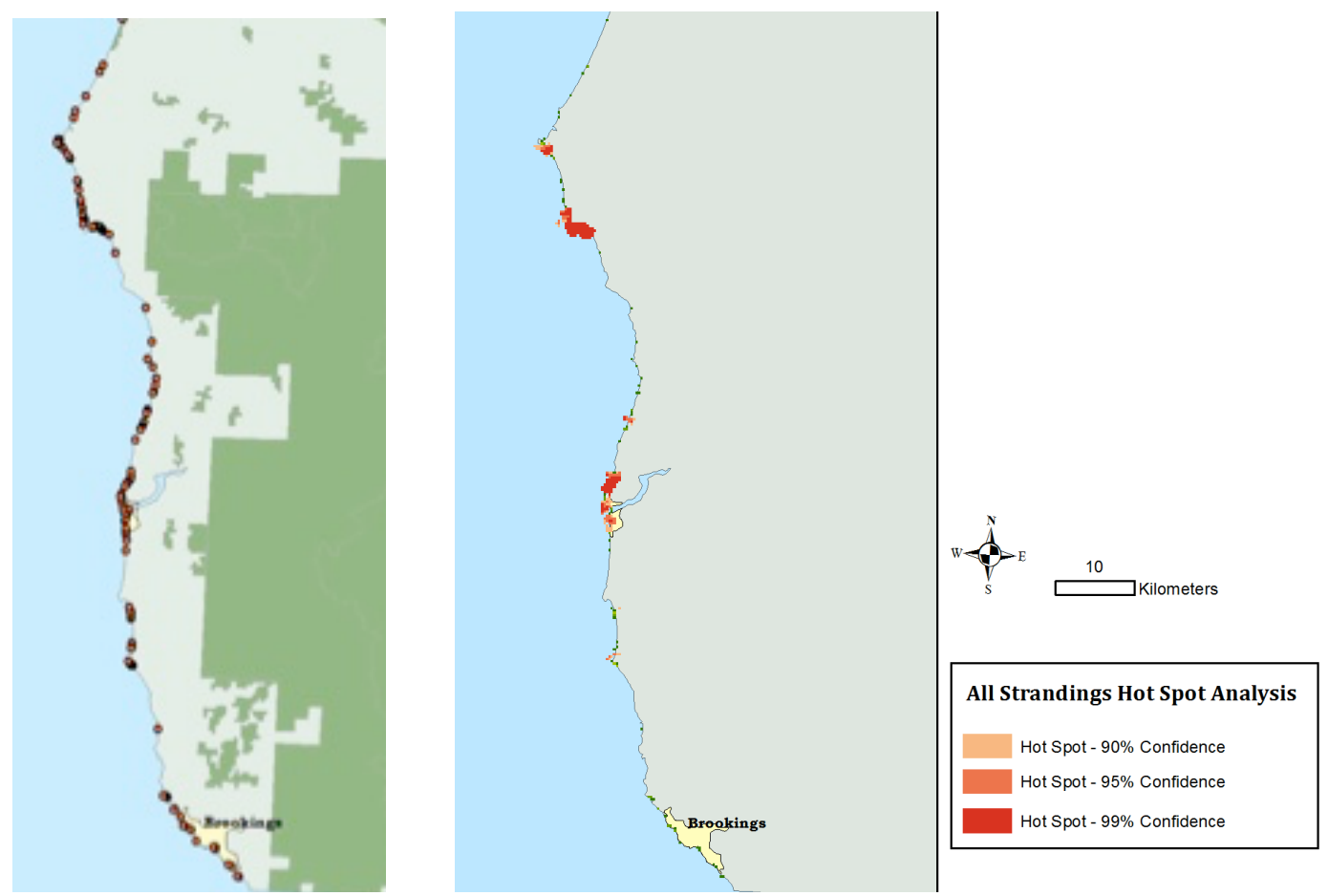

E. All sea lion strandings (left) and results of Hot Spot Analysis (right), 2006-2014, southern Oregon to the California border

Figure 2.14: Maps of all sea lion strandings, 2006-2014 (left); Hot Spot Analysis of all sea lion strandings, 2006-2014 (right). 


\section{Chapter 3: Characterization of sea lion strandings by cause of death, environmental factors, and anthropogenic activities}

\section{Introduction}

Stranding networks perform necropsies on marine mammals in order to gain insight into cause of death. Whether death is due to illness, malnutrition, human interaction, or causes such as shark attacks and other natural injuries, documenting these factors can provide the foundation for conservation and management measures. Cause of death (COD) is first evaluated by external examination and then necropsy. Provided the carcass is fresh, subsequent histopathologic examination of tissues occurs. Examination and measurements can be used to identify malnutrition. Indicators of illness, such as the presence of tumors and infections, can be observed during necropsy, and histopathology can confirm these diagnoses, as well as indicating the presence of other illness or infection. When illness is determined to be the COD, the stranding is assigned the category ILL in this analysis.

In the U.S., every stranded marine mammal must be examined for evidence of human interaction (HI). Guidelines for recognizing and documenting human interaction have been standardized across stranding networks (Moore et al. 2007) and the Level A data sheet contains a multiple choice question, "Findings of human interaction?" with possible responses of YES, NO, or CBD (Could not Be Determined). 
Federal guidance calls for these evaluations to be conservative, essentially stating that all animals are CBD until proven otherwise. When evidence of human interaction is found, the objective answer to the above question is YES. If this human interaction appears to be the cause of death, then COD is assigned the category of HI. Human interaction includes gunshot wound, net entanglement, ingestion of marine debris, and propeller or boat strike. Between 2006 and 2014, considerable seasonal variation in HI strandings was observed. This chapter examines whether this was due to higher concentrations of sea lions in areas that are also densely populated by humans and/or heavily used by commercial and sport fishermen.

Animals are also examined for signs of injury, whether those injuries are determined to be the cause of death or not. The most common injury responsible for marine mammal mortality is shark predation. In the event of apparent injuryinduced mortality that is not related to human interaction, the COD is assigned the category INJURY in this analysis. In cases where there is evidence of multiple factors, such as injury as well as evidence of advanced illness, the animal is assigned two COD categories, INJURY and ILL.

In 2009-2010 there was a moderate El Niño event, leading to warmer than usual sea surface temperature in the California Current (Fig. 3.1). This resulted in an increase in sea lion interactions with commercial fisheries in California, likely due to yearling animals being more prone to depredate fish from fishing gear during periods of lower prey availability (Keledjian \& Mesnick 2013). This was followed in January 2013 by a California sea lion pup UME that persists into spring of 2016. While these events manifest in more pronounced ways in California due to the 
presence of the rookeries and vulnerable pup populations, it's important to assess whether the effects are also impacting migratory male California sea lions, as well as Steller sea lions in Oregon. With 2015 bringing the mysterious 'warm water blob' as well as an additional El Niño in 2015-2016, establishing a baseline with which to compare future impacts of these anomalies will make it possible to measure any increased mortality and inform predictive models.

The presence of significant monthly variation in strandings may be a consequence of the increased number of animals in the area during those months, but should also be evaluated in concert with anthropogenic activity in the area, including the numerous fisheries in Oregon's offshore and nearshore waters, as well as the state's largest estuaries and the Columbia River. For purposes of stranding evaluation, offshore fisheries were not compared with strandings, but the nearshore fisheries of highest volume (Chinook and Coho salmon) and commercial value (Dungeness crab) were compared with frequency of strandings during the months the fisheries were operational. Correlations with fisheries could indicate resourceuse conflicts and guide managers in determining actions to mitigate such conflicts.

With the impacts of global climate change manifesting as altered ocean chemistry, temperature anomalies, and subsequent changes in prey availability, it is vital to be aware of responses to these changes at various trophic levels. Monitoring seasonal or geographic trends in marine mammal strandings, whether due to illness, human interaction, injury, or a combination of these factors is critical to understanding ecosystem impacts of changing ocean conditions. Assessing distribution of strandings by particular COD can be useful in determining whether 
environmental or anthropogenic factors contribute to increased strandings at certain times of year and/or in certain geographic areas.

\section{Methods}

After analyzing initial distribution of strandings, the data were queried by cause of death. Cause of death was recorded from Level A stranding network reports according to the following categories: Human Interaction (HI), Illness (ILL), Injury (INJURY), and Could Not Be Determined (CBD). Human Interaction was assessed based on external and internal evidence of trauma, recovery of bullets or shotgun pellets during necropsy, external evidence of net entanglement, and injuries consistent with boat propeller strike. A determination of illness is based on body condition, necropsy, and histopathology. Injury was associated with naturally occurring injury, most commonly predation by sharks.

The different life histories of the two species, particularly differences in range and migratory behavior, suggest that they should be analyzed separately as well as together. Due to differences in capacity of the two stranding network regions, strandings were analyzed separately for the PSU and HMSC regions. Strandings were analyzed by month and by cause of death using Chi-square Goodness of Fit. One Way ANOVA was used to compare monthly strandings by species and COD with the presence of commercial fisheries. 


\section{Results}

From 2006-2014, of the 1532 sea lion strandings, 245 (16\%) were due to human interaction (HI), 153 (10\%) were due to illness (ILL), 31 (2\%) were due to injury (INJURY) and1103 (72\%) could not be determined (CBD).

The PSU network (n=445) was comprised of 223 (50\%) HI, 58 (13\%) ILL, 13 (3\%) INJURY, and 151 (34\%) CBD (Fig. 3.2).

The HMSC network data (n=1087) showed 22 (2\%) HI, 98 (9\%) ILL, 22 (2\%) INJURY, and 946 (87\%) CBD (Fig. 3.3). The disparity in proportion of CBD strandings between the two networks is reflective of the difference in response and necropsy capacity.

The PSU HI strandings showed significant temporal variation in 2008 (n=23, $p=0.015)$ with the greatest frequency in December; in $2009(n=35, p=0.004)$ highest in January and September; in $2010(n=35, p<0.0001)$ highest in September, October, and November; in 2012 ( $\mathrm{n}=28, \mathrm{p}=0.0008$ ) highest in May, June, and September; and in 2013 (n=38, p=0.007) highest in March, May, and September (Fig. 3.4). PSU HI strandings for all years in the dataset, 2006-2014, were significant in May $(\mathrm{p}<0.0001)$, June $(\mathrm{p}<0.0001)$, and September $(\mathrm{p}<0.0001)$. PSU HI strandings of California sea lions were significant in September $(\mathrm{p}<0.0001)$, and PSU HI strandings of Steller sea lions were significant in May $(p=0.0548)$ and June $(\mathrm{p}=0.0548)$. The HMSC HI strandings did not show statistical significance, likely due to the small proportion of sea lions with known cause of death. PSU HI strandings peaked in 2009 and 2010, decreased in 2011, and increased again in 2012, 2013, and 2014 (Fig. 3.5). 
Strandings due to illness accounted for $13 \%$ of PSU strandings and $9 \%$ of HMSC strandings. There was no significant monthly variation, due to the relatively small proportions in any particular month. If both regions are considered, September, October, and November contain the highest number of ILL strandings, consistent with the overall stranding numbers, and the highest frequency of ILL strandings occur in 2009 and 2010, which also coincides with a moderate El Niño phase, but all strandings peaked during those years, so it does not appear that the warming event caused disproportionate amounts of strandings due to illness (Fig. 3.6).

The greatest number of sea lion strandings in the study occurred in 2009 $(n=308)$ and $2010(n=279)$. This coincides with a moderate ENSO event. While prior research indicating that El Niño events affected California sea lion foraging behavior were done in California (Weise et al. 2006), it is possible that the impacts of this warming phase contributed to increased mortality in this time period in Oregon as well.

Using Chi-square Goodness of Fit, temporal stranding hotspots due to human interaction in the PSU region correlated with the Dungeness crab fishery in December 2008-January 2009, with spring Chinook fisheries in June of 2010, MayJune of 2012, and May of 2013, and with ocean and Columbia River Coho in September of 2009, September and October of 2010, September of 2012, and September of 2013.

One-way ANOVA indicates PSU total strandings for all years correlate with the presence of the Chinook salmon fishery (May-October) as expressed as a binary 
variable based on volume of catch (fishery open $=1$, fishery closed or catch negligibly low $=0),(F(1,106)=5012, \mathrm{p}=0.0257)$. PSU HI strandings for all years also correlate with the Chinook salmon fishery as determined by one-way ANOVA (again with fishery expressed as a binary variable, 0 or 1$),(F(1,106)=4.42, \mathrm{p}=0.0380)$. Binary Logistic Regression indicates that the PSU California sea lion strandings correlate with the Coho salmon fishery when expressed by actual volume of catch per month $(p=0.004)$ and the Chinook salmon fishery $(p=0.017)$, but not the Dungeness crab fishery ( $\mathrm{p}=0.623$ ) (see Appendix B: fisheries data).

Steller sea lion strandings clustered in southern Oregon near the rookeries at Orford Reef and Rogue Reef (Fig. 3.7), but over the rest of the study area there were no statistically significant hot spots, likely due to the smaller overall proportion of the species in the dataset. California sea lions showed multiple stranding hot spots, particularly on Washington's Long Beach Peninsula and in and around Astoria and Seaside, Oregon, as well as around the South Jetty of the Columbia River. Hot spots are also evident in the Lincoln City area, Newport and south, in Florence, as well as south of Coos Bay and at the Rogue River estuary (Fig. 3.8). Breaking the strandings down further into COD did not yield statistically significant hot spots, but when the HI stranding points are displayed on the map, they occur in larger numbers on the Long Beach Peninsula, Astoria, Seaside, and the South Jetty (Fig. 3.9).

During the study period there was a weak El Niño event during 2006-2007, and a moderate El Niño event in 2009-2010. A moderate La Niña followed in 20102011, and a weak La Niña in 2011-2012 (Fig. 3.1). Strandings were evaluated in the context of the Pacific Decadal Oscillation and the Oceanic Niño Index. With the PDO 
in a negative (cool) phase from 2007-2009 before reverting to a positive (warm) phase in 2009, it could be expected that salmon returns would be high in 2010 and decline in 2011 and 2012. If spring Chinook salmon returns decline, HI strandings could increase as a result of increased competition between sea lions and fishermen. The increases in strandings in 2009 and 2010 could be related to the El Niño phase that occurred during those years, causing prey fish to move further offshore to cooler waters, as well as to experiencing increased competition with fisheries due to California sea lion population growth and increased abundance of the species in Oregon.

\section{Discussion}

The impacts of climatic oscillations can be somewhat challenging to correlate with stranding events in a given year, as trophic manifestations may not be evident in the same year as the measurable oscillation (Mantua et al. 1997). This is particularly true of the Pacific Decadal Oscillation (PDO), characterized by warm (positive) or cool (negative) cycles that have historically lasted for decades but has recently switched from neutral to negative in 2007 and then reverted to a positive phase in 2009. A time lag of up to two years exists between PDO phase changes and spring Chinook salmon returns. Fish entering the sea during a positive PDO signal experience poor conditions that lead to poor returns two years later (Mantua et al. 1997).

The Oceanic Niño Index refers to El Niño Southern Oscillation (ENSO), a warming event, and La Niña, a cooling event. Both the PDO and ONI can be viewed 
as leading indicators of ocean conditions since after a persistent change of either index, ocean conditions in the California Current soon begin to change (Mantua et al. 1997). El Niño events have been found to affect foraging behavior of California sea lions, increasing foraging distances and reducing availability of high quality prey (Weise et al. 2006). Human Interaction was the leading known COD of PSU strandings and, like strandings overall, peaked in 2009-2010, possibly due to the effects of an El Niño event. Strandings due to HI also correlate with seasonal commercial salmon fisheries in Oregon and southern Washington, and while impacts of PDO and El Niño are not necessarily seen in salmon returns until two years after the warming event, as ocean conditions continue to fluctuate, increased numbers of California sea lions in Oregon could coincide with poor salmon returns, exacerbating competition between sea lions and commercial fisheries and resulting in increased frequency of sea lion mortality due to human interaction . 


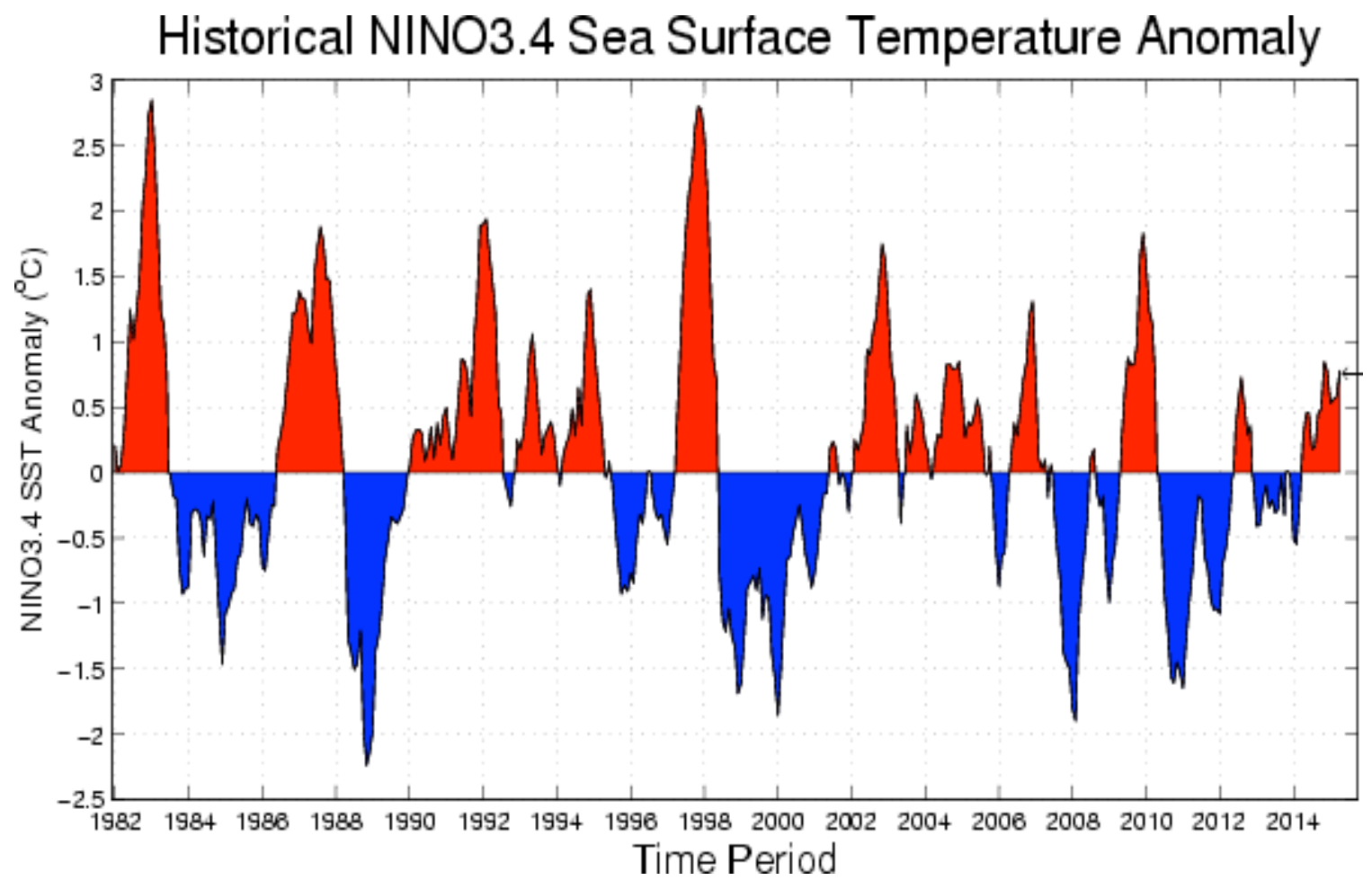

Figure 3.1: El Nino Southern Oscillation, 1982-2014; El Nino (warming) phases in red, La Nina (cooling) phases in blue (National Weather Service Climate Prediction Center/NOAA). 


\section{PSU COD, 2006-2014}

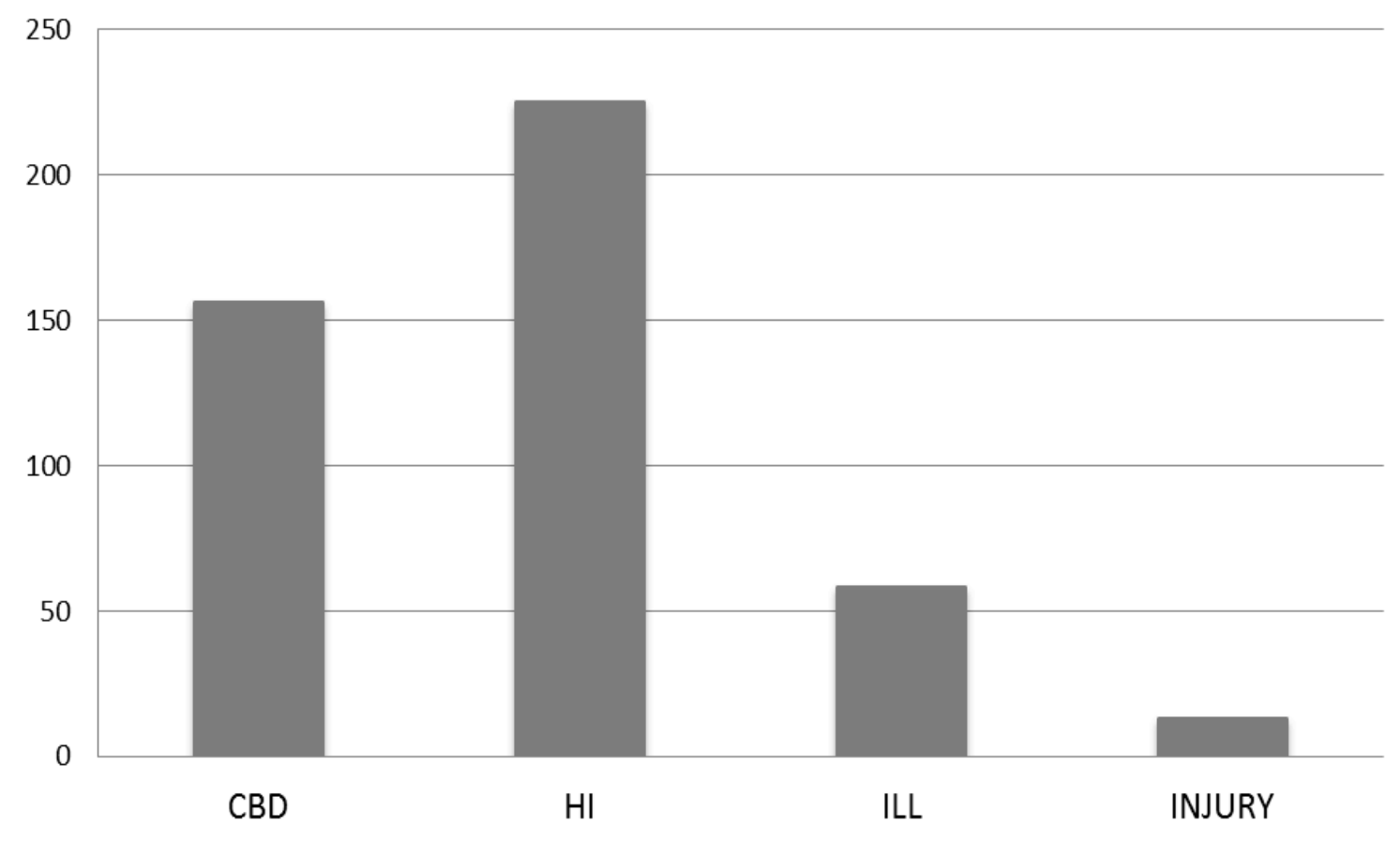

Figure3.2: PSU strandings by cause of death (COD); Could Not Be Determined (CBD)=156; Human Interaction (HI)=225; Illness (ILL)=58; Injury=13.

HMSC COD, 2006-2014

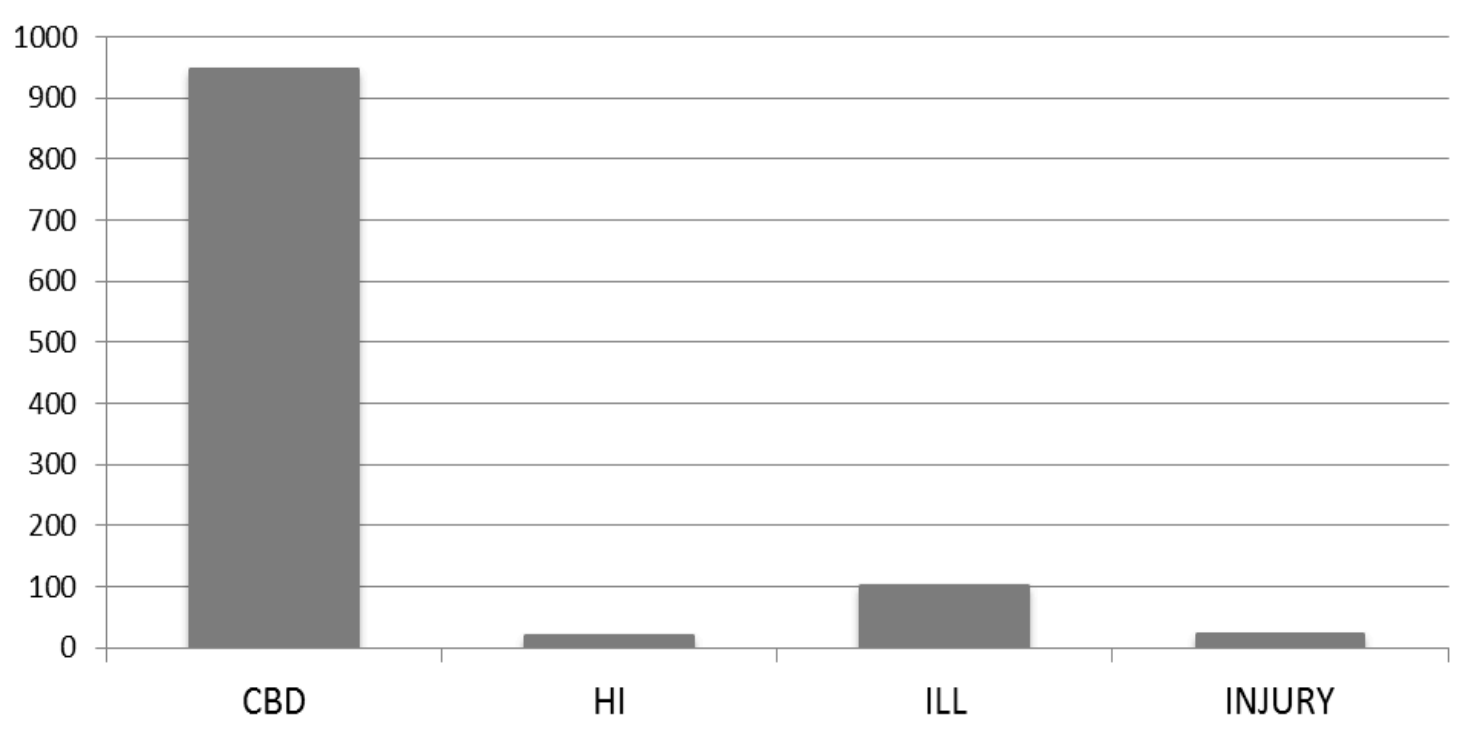

Figure3.3: HMSC strandings by cause of death (COD); Could Not Be Determined (CBD)=946; Human Interaction (HI)=20; Illness (ILL)=100; Injury=21. 


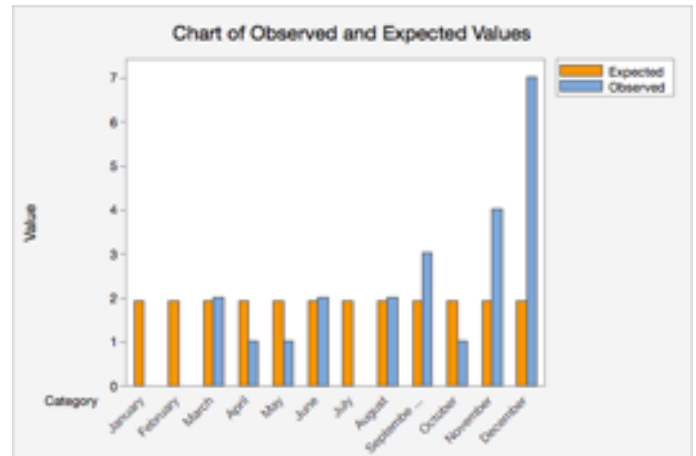

PSU California sea lion HI 2008: $n=23, p=0.0153$

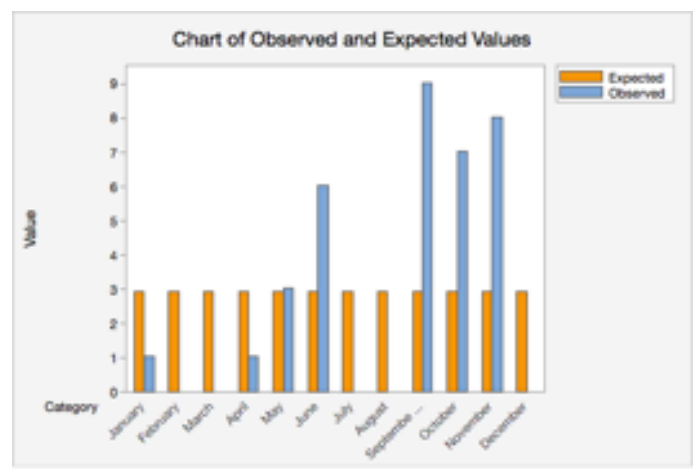

PSU California sea lion HI 2010: $n=35, p<0.0001$

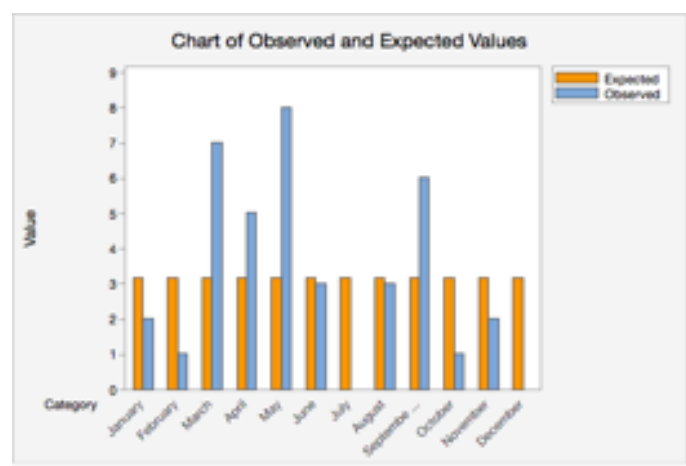

PSU California sea lion HI 2013: $n=38, p=0.0070$

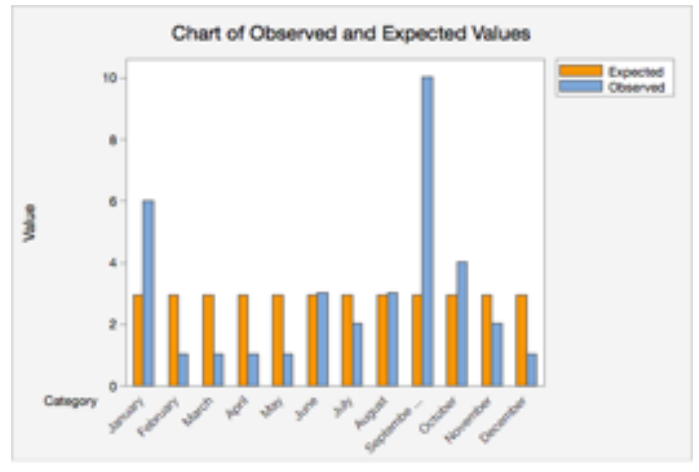

PSU California sea lion HI 2009: $n=35, p=0.0035$

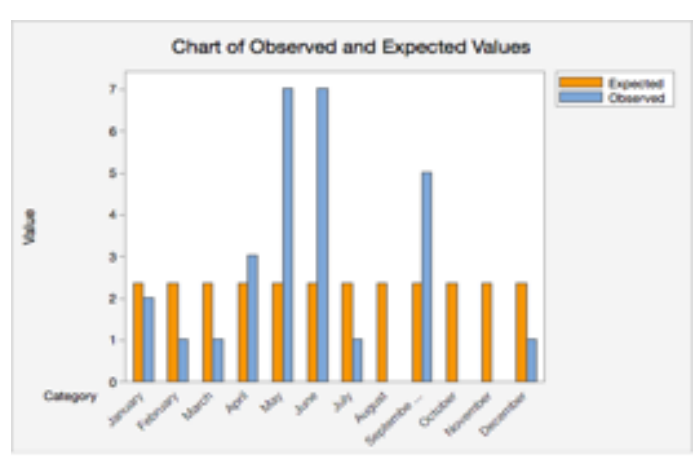

PSU California and Steller sea lion HI 2012: $n=28$, $\mathrm{p}=0.0008$

Figure3.4: Chi-Square Goodness of Fit test for PSU Human Interaction (HI) strandings; 2006, $2007,2011,2014$ no statistical significance $(p=0.05)$ for PSU HI. 


\section{PSU total HI}

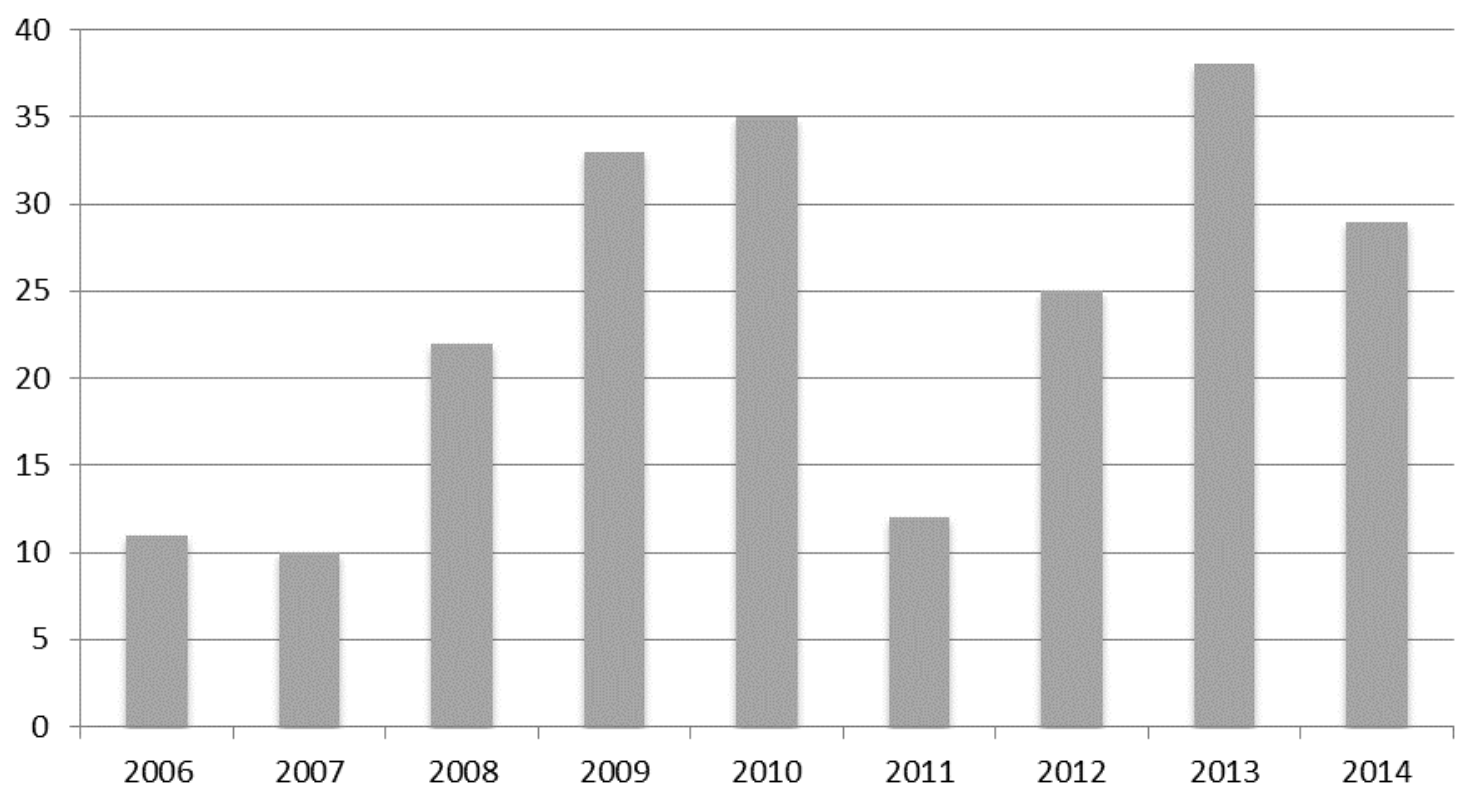

Figure3.5: All PSU Human Interaction strandings, 2006-2014.

\section{All ILL, 2006-2014}

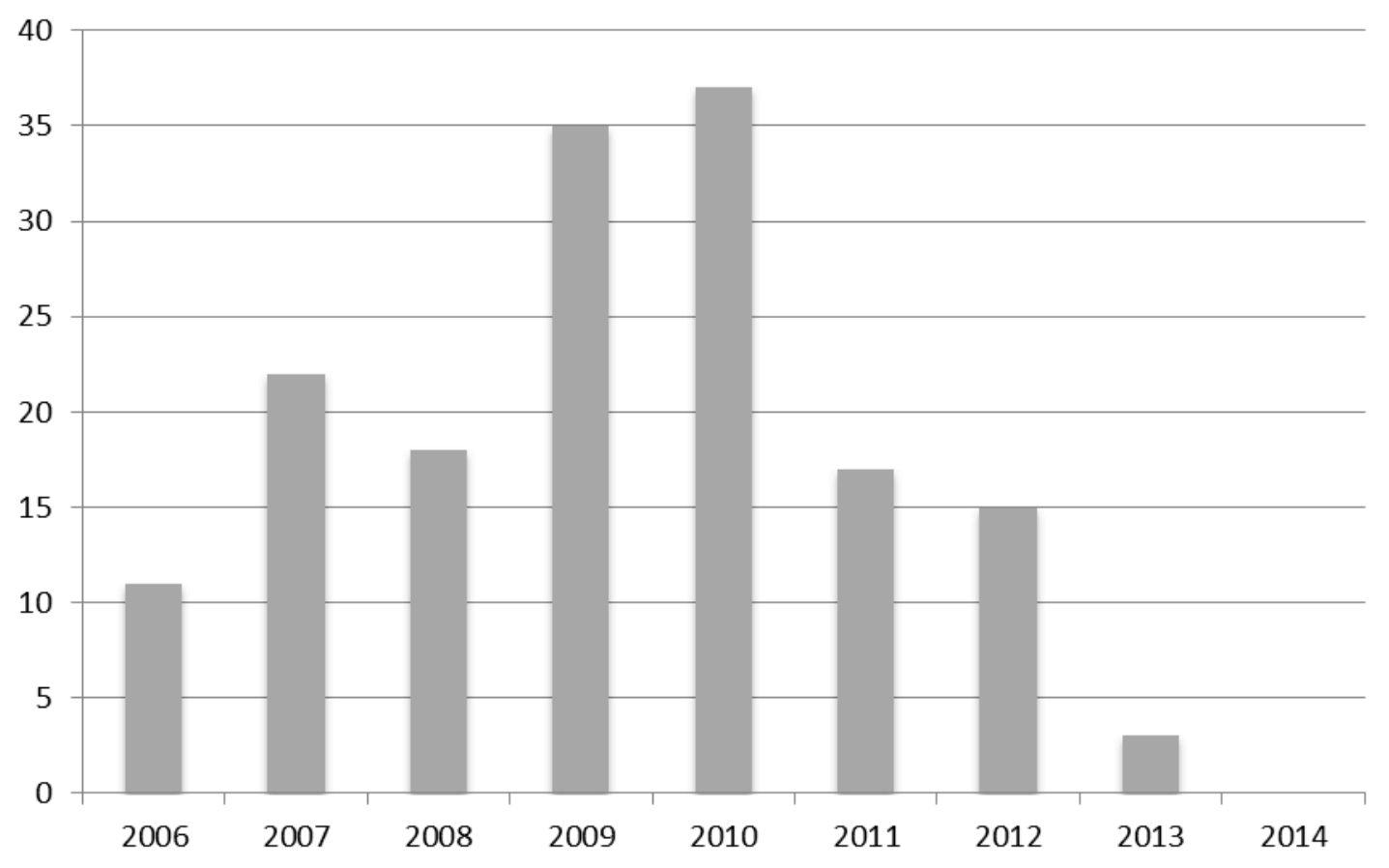

Figure 3.6: All California and Steller sea lions due to Illness, 2006-2014. 


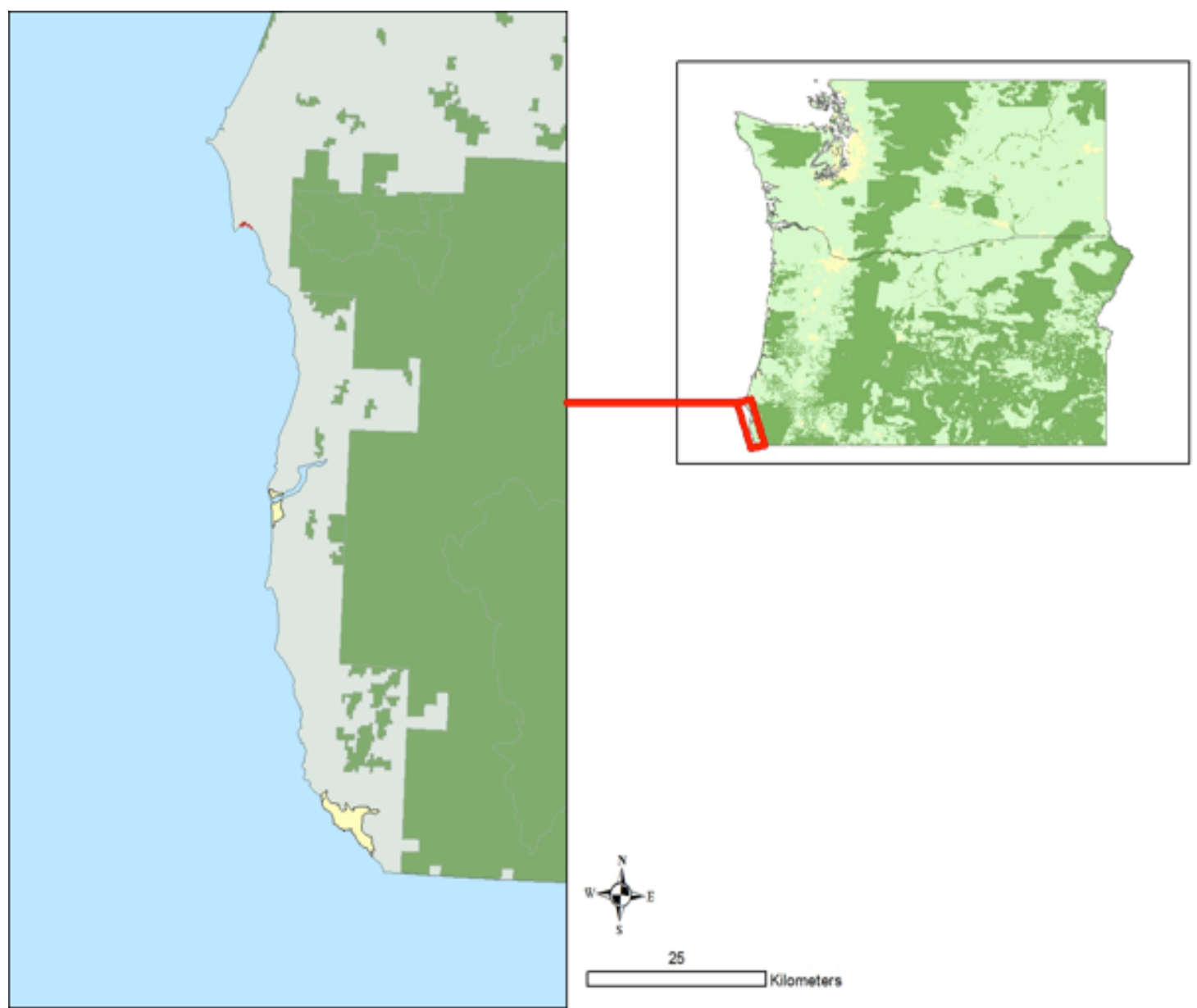

Figure 3.7: Hot Spot Analysis by species, Steller sea lions 2006-2014. The only statistically significant hot spots were near the rookeries in southern Oregon. 


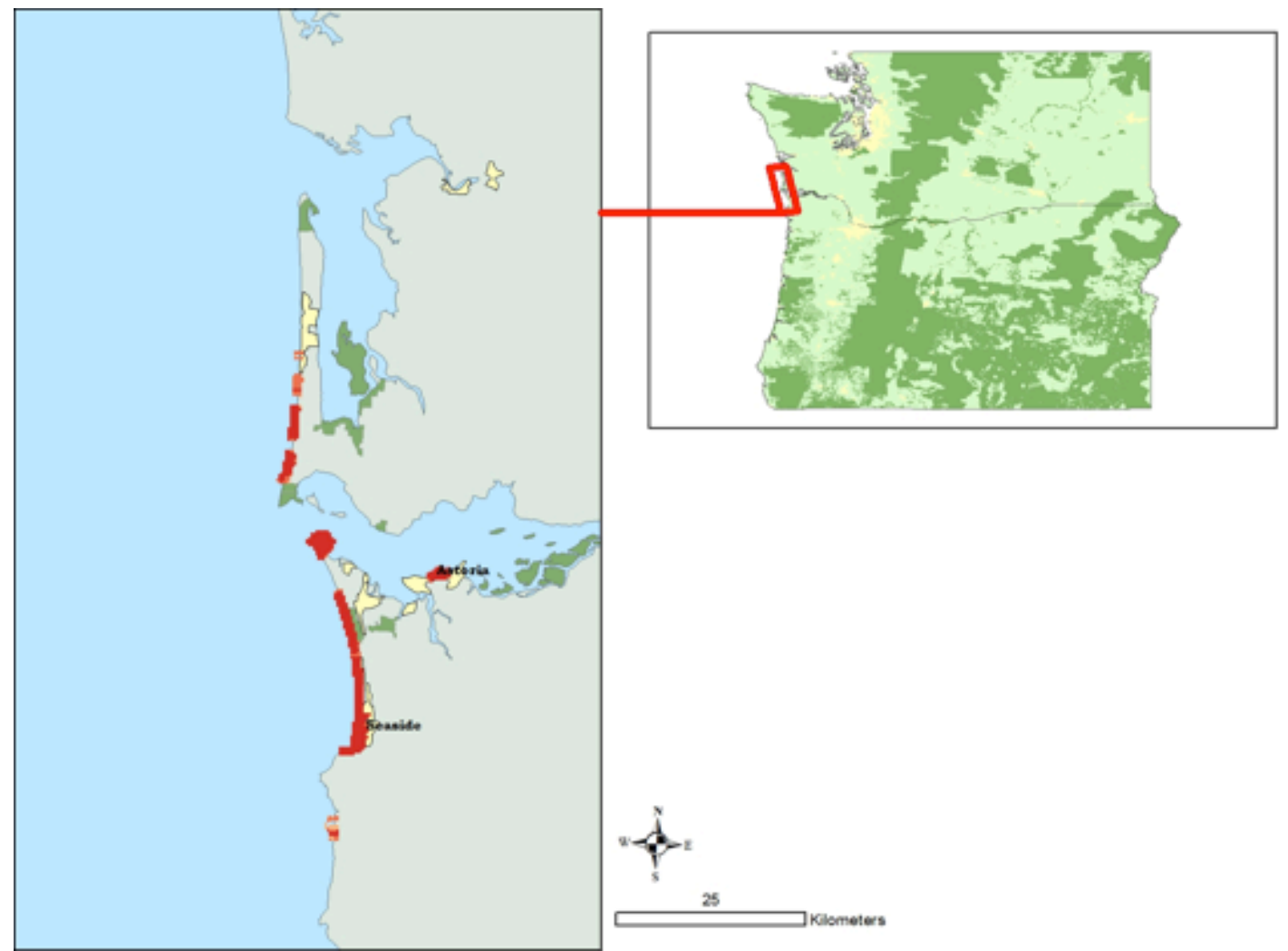

Hot Spot Analysis, California sea lions, 2006-2014, Long Beach Peninsula, WA, Astoria to Seaside, OR

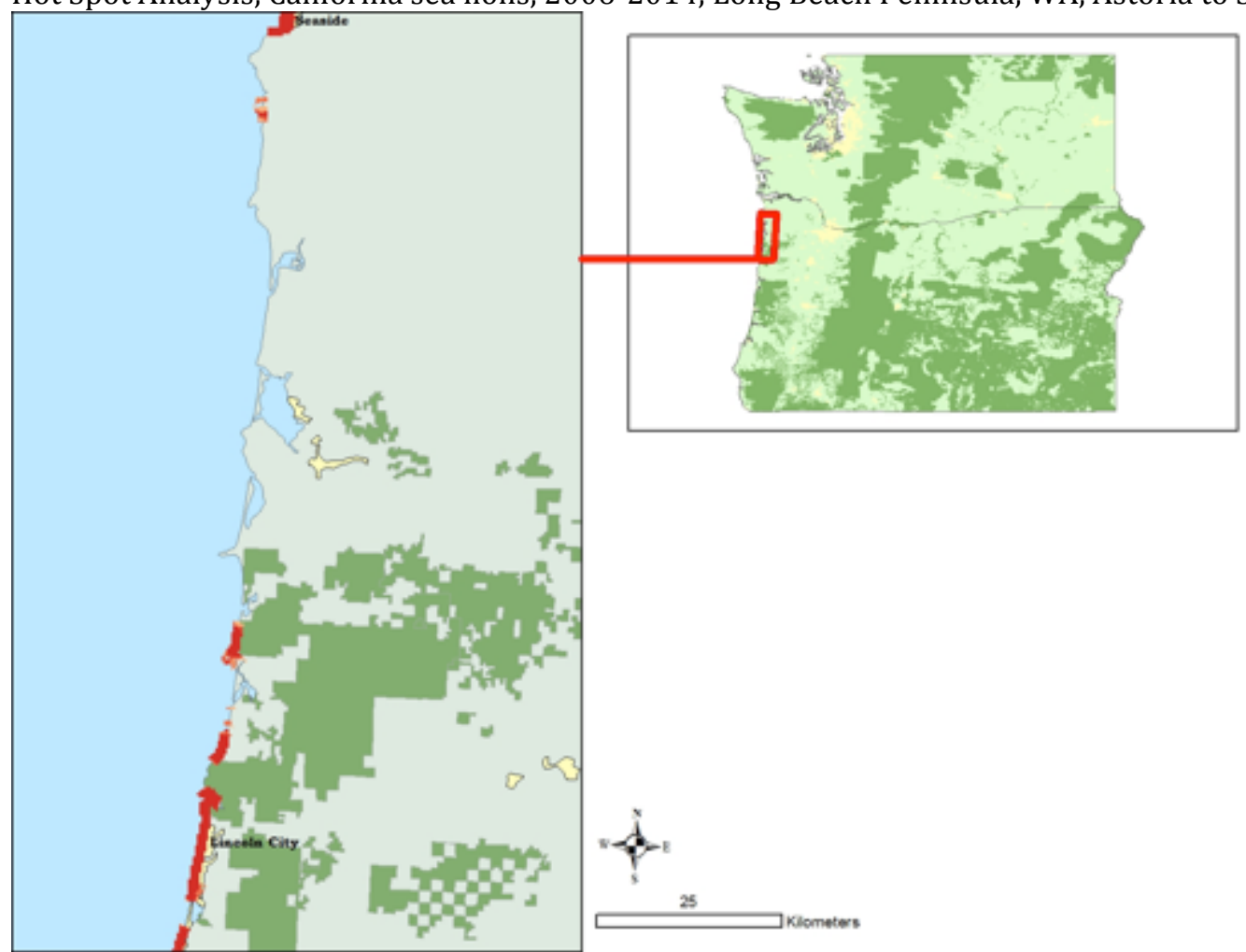

Hot Spot Analysis, California sea lions, 2006-2014, Seaside to Lincoln City 


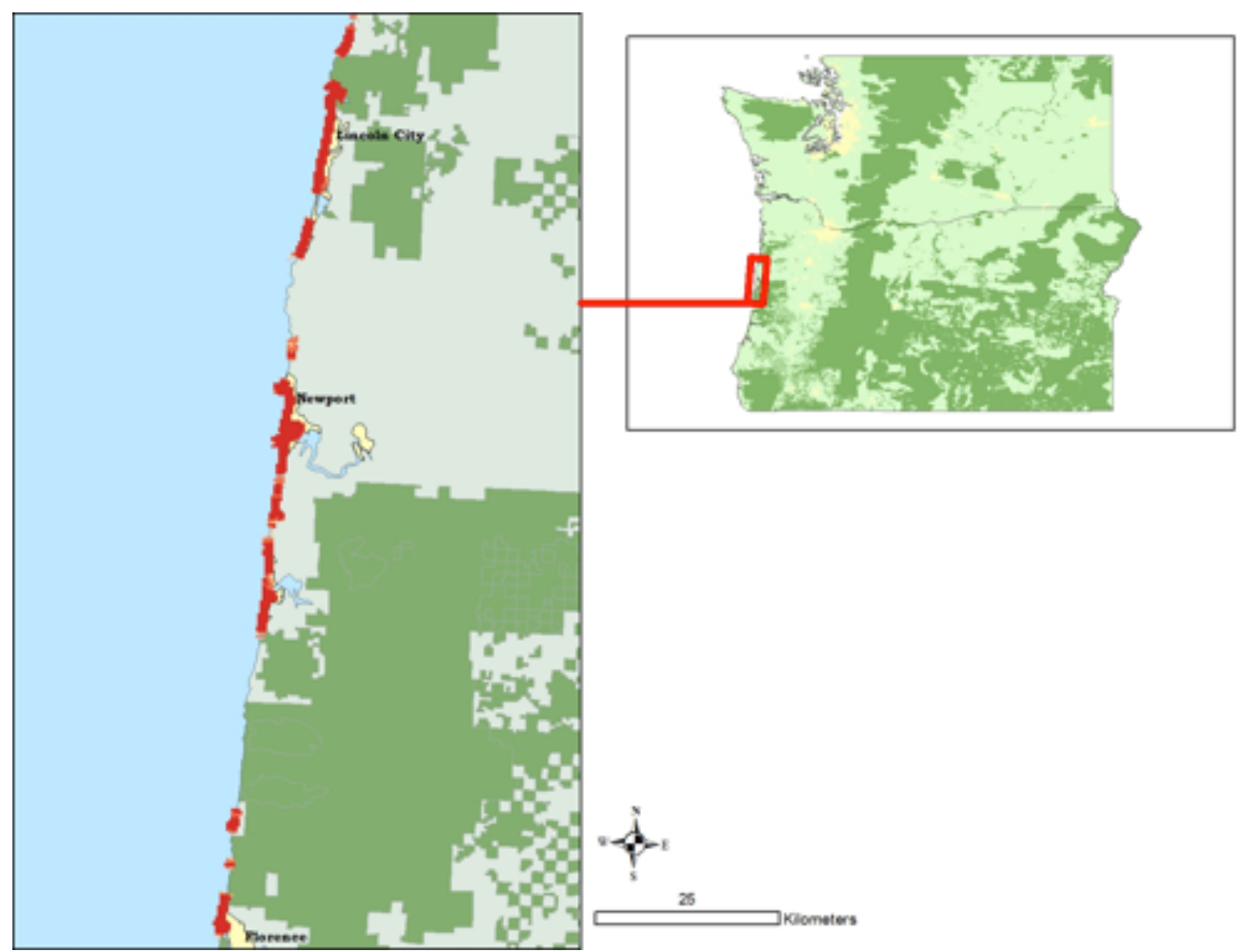

Hot Spot Analysis, California sea lions, 2006-2014, Lincoln City to Florence

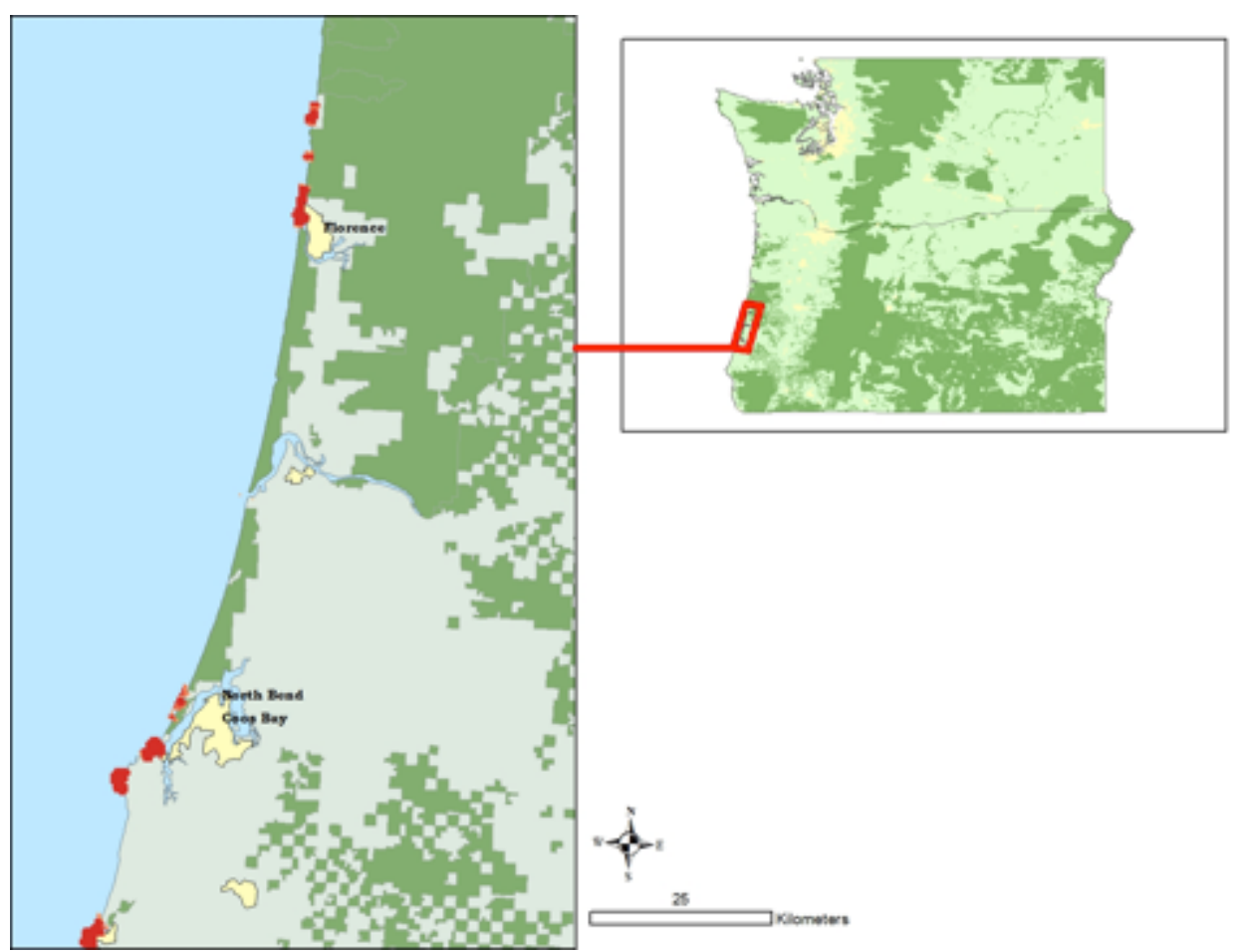

Hot Spot Analysis, California sea lions, 2006-2014, Florence to south of Coos Bay 


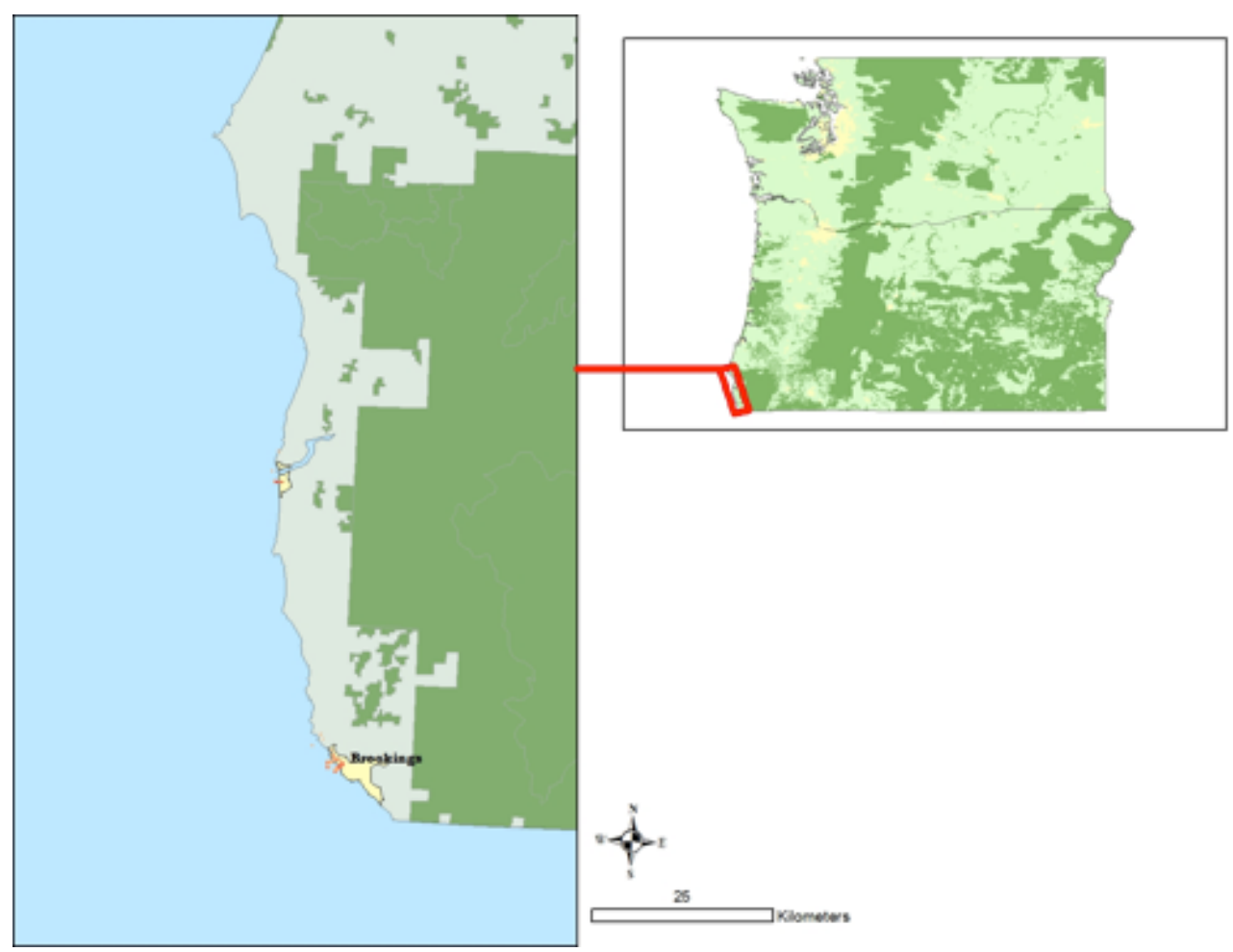

Hot Spot Analysis, California sea lions, 2006-2014, southern Oregon to the California border Figure 3.8: Hot Spot Analysis of California sea lion strandings, 2006-2014. 


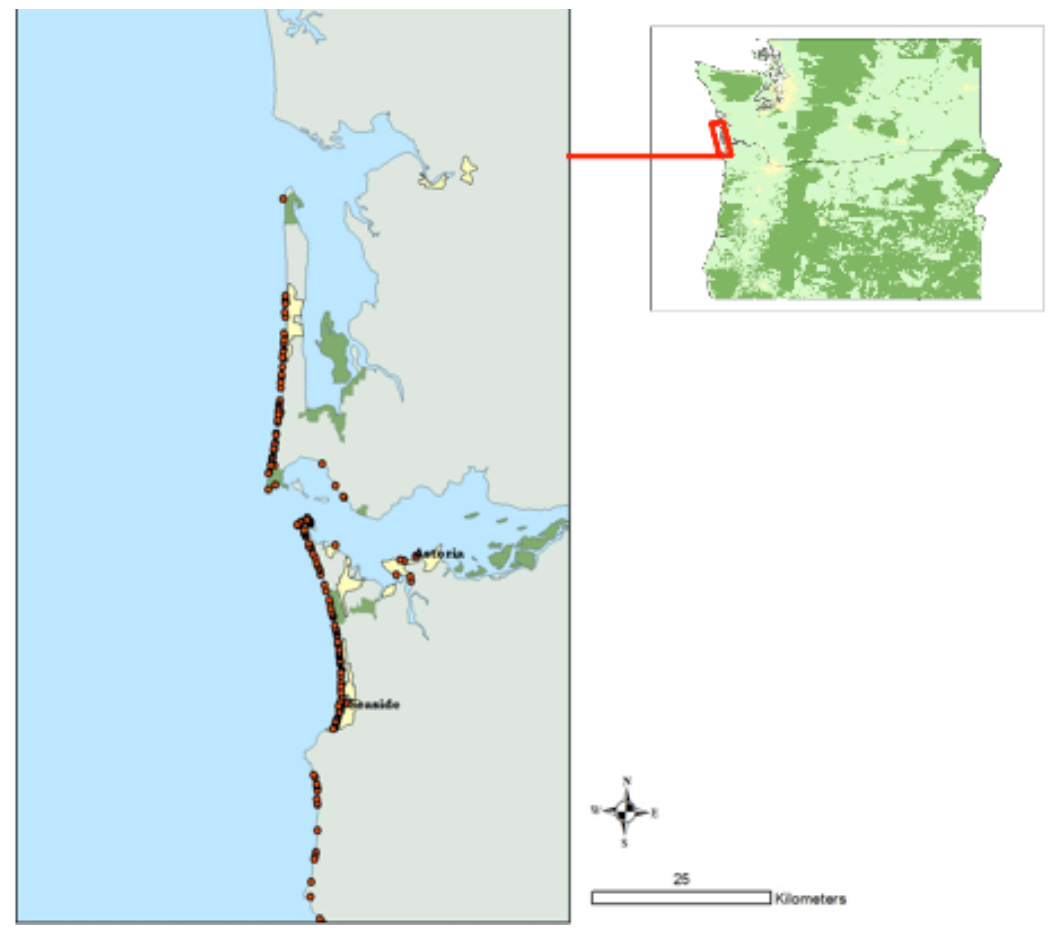

HI strandings, 2006-2014, Long Beach Peninsula, Washington, Astoria to Seaside, Oregon

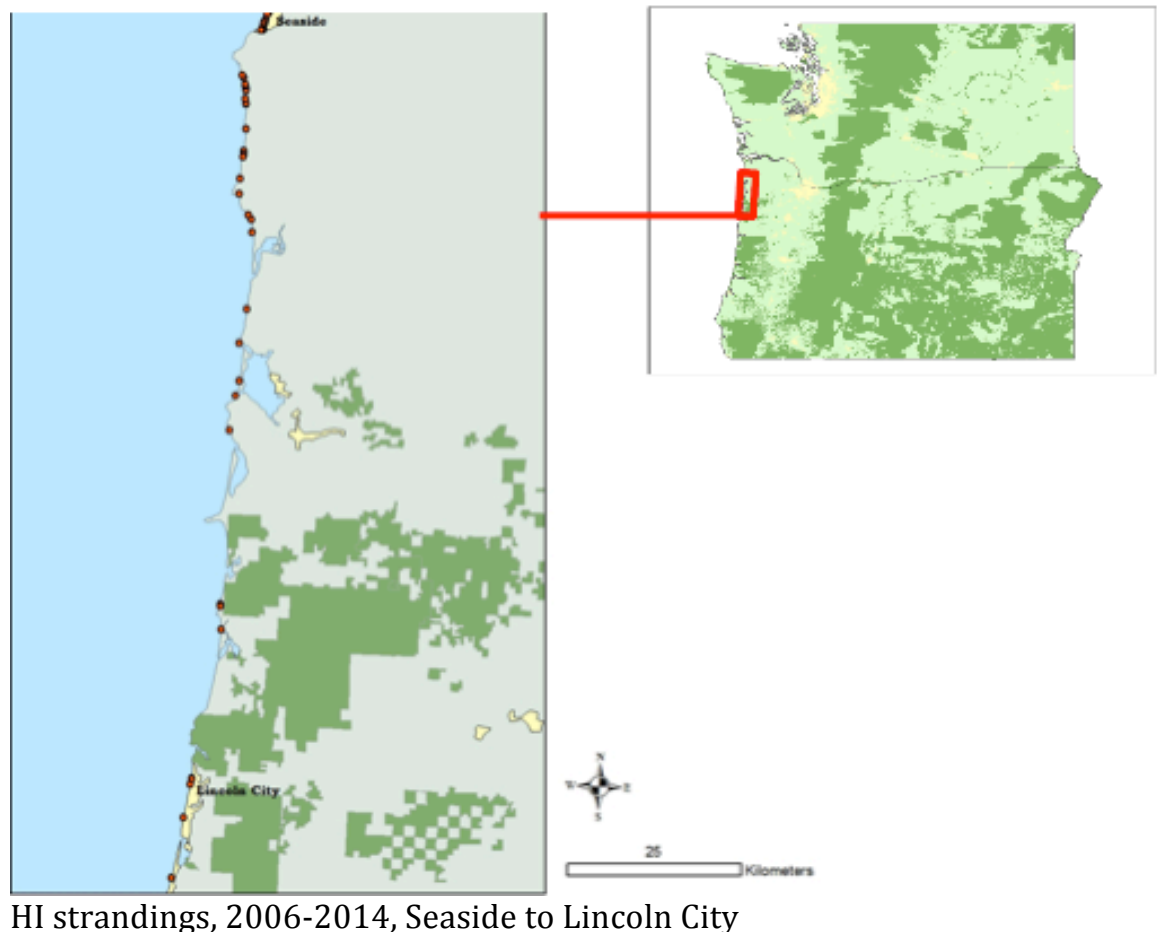

HI strandings, 2006-2014, Seaside to Lincoln City 


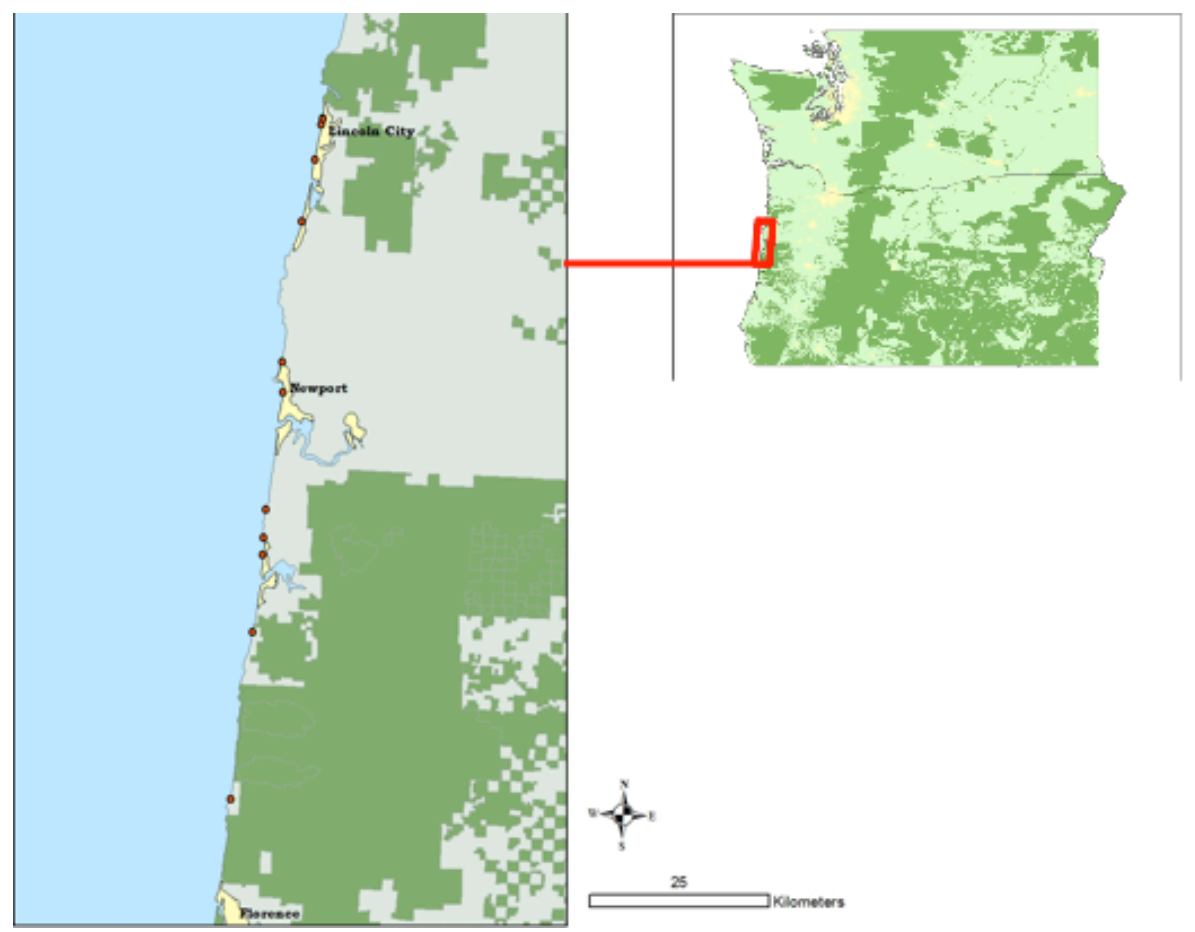

HI strandings, 2006-2014, Lincoln City to Florence

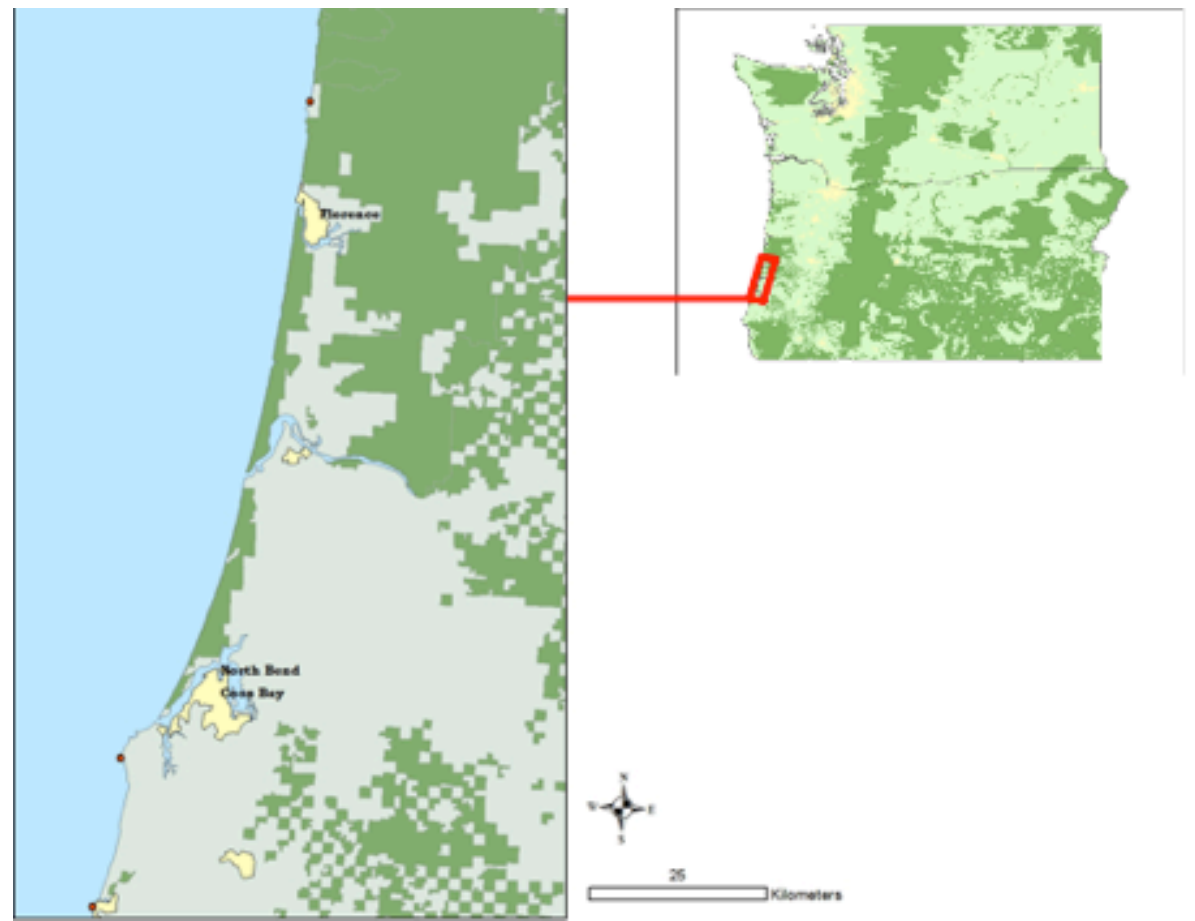

HI strandings, 2006-2014, Florence to south of Coos Bay 


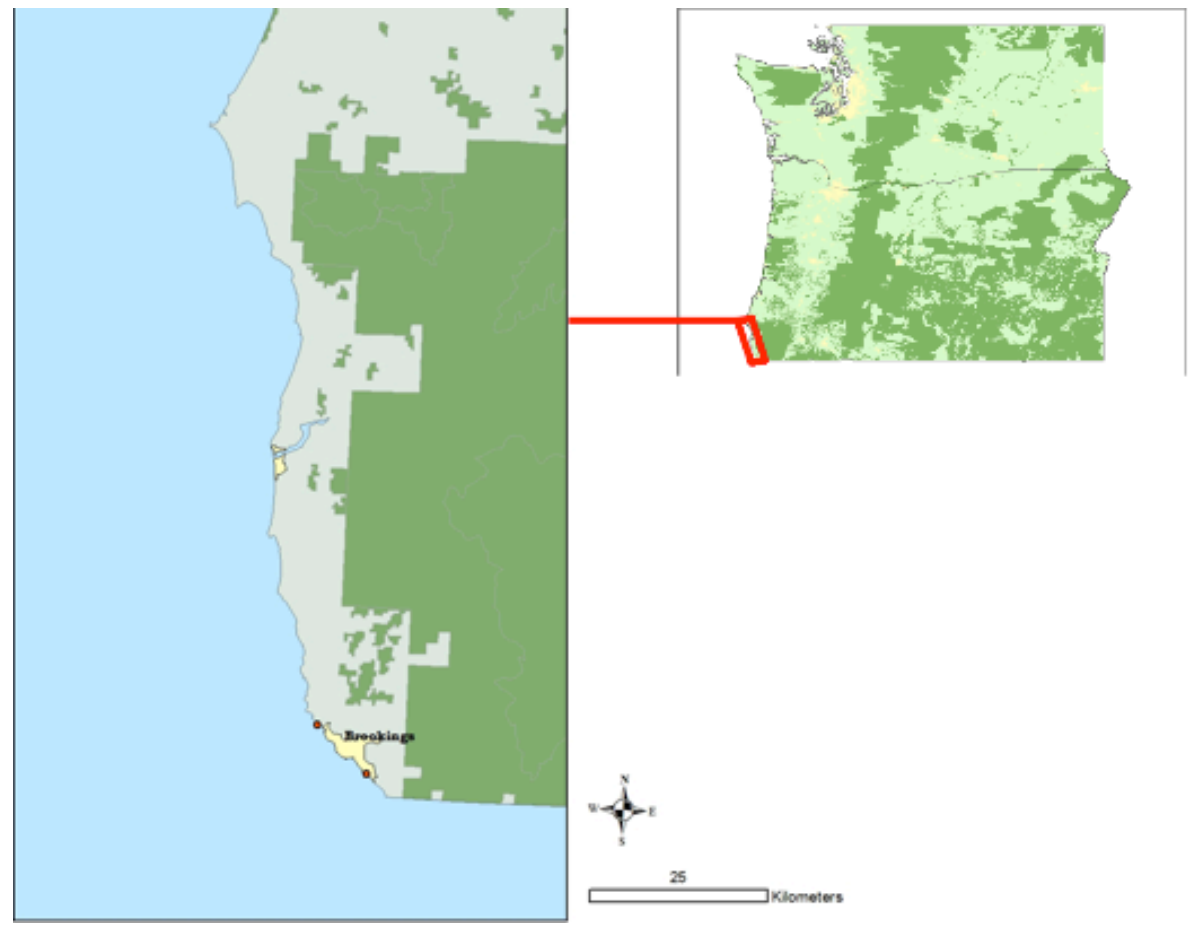

HI strandings, 2006-2014, southern Oregon to the California border Figure 3.9: Human Interaction stranding points, 2006-2014. 


\section{Chapter 4: Discussion \& Conclusions}

As populations of sea lions have increased in the years following the passage of the Marine Mammal Protection Act of 1972, annual numbers of strandings have increased as well. There is an important perspective to be gained by aggregating stranding data collected over time and assessing whether certain species demonstrate any seasonal or geographic trends. The focus of this thesis was to begin with an overall view of strandings of two similar species, California sea lions and Steller sea lions, over nine years, determine whether those species exhibited patterns in monthly or geographic strandings, then zoom in on causes of death, and consider climatic cycles, population density and fisheries activity as possible correlates with higher numbers of strandings.

While stranding networks exist around the country by federal mandate, capacity to respond to each reported stranding varies based on a network's personnel resources, the extent of the geographic area in the response network, and the volume of strandings reported. The coast of Oregon is under public ownership from the water up to sixteen vertical feet above the low tide mark, theoretically making it possible for a stranding to be discovered by the public anywhere on the coast, other than inaccessible cliffs and rocky shorelines. The PSU network utilizes its resources and personnel with the goal of responding to every stranding report, and necropsying every animal unless geography or hazardous conditions make access impossible. Because of this focused effort, the PSU network has a much higher proportion of animals with known COD. Given that the populations of sea 
lions that strand in the PSU network are the same populations that strand in the HMSC network and that conditions are similar in terms of geography, ocean conditions, human density and activities, it is possible that the more thorough understanding of causes of sea lion strandings obtained by the PSU network could be applied to HMSC strandings in which COD is more often undetermined. In this way, the PSU strandings could serve as a model for interpreting HMSC network sea lion strandings, which occur in nearly double the numbers but for which much less data exist. In both Oregon stranding networks, Steller sea lion strandings are most significant in the summer (PSU in May and June, HMSC in July and August), and California sea lion strandings are most significant in the fall (both PSU and HMSC in September, October, and November), consistent with the life history activities of the two species. Steller sea lions are congregating at rookeries in large numbers in Oregon during the summer months, while the migratory male California sea lions are at the Channel Islands rookeries in California during those early summer months, but have returned to Oregon following the breeding season, thus are present in large numbers from September through May-June. Strandings due to Human Interactions are significant in the PSU stranding network region in May and June for Steller sea lions and September, October, and November for California sea lions, mirroring the overall stranding pattern for the two species, and it's reasonable to suspect that similar trends exist in the HMSC network region.

Human Interaction as COD peaked in 2009 and 2010 and decreased in 2011. HI strandings increased again in 2012 and continued to increase in 2013 and 2014. These peaks correspond to climatic oscillations that effect prey movement and 
availability and thus, movement of sea lions and increased potential for fisheries interactions. Moreover, as ocean conditions continue to fluctuate and sea surface temperatures continue to drive prey fish further north (Weise et al. 2006), California sea lion yearlings and subadults are now migrating in greater numbers, and peak observed counts at haulout sites have increased dramatically from what they were at the beginning of the study period, from a peak of 165 animals at East Mooring Basin in Astoria in 2006, to 2340 animals at the same haulout in 2015 (Table 1, Pacific States Marine Fisheries Commission unpublished data).

Spatial analysis in ArcGIS demonstrated that, while strandings occur over the entire Oregon and southern Washington coast, there are hot spots near population centers and estuaries that are also the locations of major coastal fishing ports. These stranding hot spots are likely due to increased occurrence of human interaction related to higher population density and higher prey availability in these estuaries with concomitant increased competition. Further studies of these hot spots and the particular nature of the stranding interactions are warranted.

Necropsies performed by the Marine Mammal Stranding Network determined whether a stranded animal was ill. From $2006-2014,10 \%$ of total strandings were due to illness (13\% in the PSU network, 9\% in the HMSC network). Identifying the distribution of illness in marine mammal strandings may prove useful in future research, and this analysis may provide spatial and temporal data that can be utilized for further investigation

Certain confounding variables still exist in stranding analyses. Stranding reports are opportunistic and discovery of a stranded animal is likely to vary with 
weather, season, and the number of people on the beach, although conservation groups currently have monthly observer coverage over nearly the entire Oregon coastline conducting bird surveys, decreasing the likelihood of a marine mammal going unreported. However, when a stranded animal is recovered there is usually no way to ascertain where the animal died. Stranding reports inherently underestimate mortality rates due to at-sea mortality in which the carcass is not recovered (Peltier et al. 2012), and the possibility exists that in more remote coastal areas, carcasses go undiscovered and unreported. To that end, with support from Oregon Sea Grant and in partnership with the NOAA West Coast Groundfish Observer Program, I have undertaken a study to assess marine mammal recovery rates. The Groundfish Observer Program maintains 100\% observer coverage on groundfish trawl fisheries in California, Oregon, and Washington. Observers document marine mammal bycatch and are required to discard the carcass from the boat following documentation. This study equipped the observers with cattle tag applicators and sets of numbered tags. When a marine mammal, pinniped or cetacean, is bycaught, the observer will apply four tags with the same number to the carcass (fore and hind flippers of pinnipeds; pectoral fins, dorsal fin, and fluke of cetaceans), photograph the tagged carcass, and record the latitude and longitude where the tagged carcass is returned to the water (Fig. 4.2). During the 2015 groundfish trawl season, twelve carcasses were tagged (10 pinnipeds and 2 cetaceans) and two pinnipeds were recovered in California, one south of San Francisco Bay, the other near Point Piedras Blancas. The study will continue through 2019. The proportion of 
tagged carcasses recovered will yield data on stranding network recovery rates, and location of origin and of recovery will provide data on carcass drift.

As climate change continues to drive changing ocean conditions, impacts will likely occur at multiple trophic levels. Marine mammals, being long-lived and feeding at high trophic levels, are likely to be impacted by climate impacts on forage fish species, harmful algal blooms, and other environmental perturbations. The information gathered from strandings will help researchers and managers determine ways in which changing ocean conditions are impacting marine ecosystems. Despite the confounding variables and opportunistic reporting, longterm analysis of strandings patterns can reveal trends among the stranded populations and can help elucidate factors contributing to marine mammal mortality.

\section{Summary}

This analysis demonstrated that, from 2006 to 2014, monthly stranding patterns existed for Steller sea lions and California sea lions in Oregon and southern Washington. Steller sea lion strandings peaked from May to August, and California sea lion strandings peaked from September to November.

Where COD could be determined, HI was the most common cause of death, and HI stranding patterns generally mirrored overall temporal stranding patterns.

Strandings peaked in 2009 and 2010, possibly related to a moderate El Niño phase. The fact that strandings of yearling California sea lions peaked in that twoyear period, increasing by approximately ten-fold and then decreasing to pre-2009 
levels, supports other observations that during warm water conditions, yearling males migrate north in search of available prey. While increasing foraging distances can be a viable strategy when local prey availability declines, there are energetic costs associated with this behavior. The increase in yearling strandings may indicate that these younger animals are less able to successfully tolerate the greater energetic expenditure associated with climatic oscillations and the accompanying increased foraging distances.

Spatial analysis shows that stranding hot spots occur near major coastal estuaries: the mouth of the Columbia River, Siletz Bay, Yaquina Bay, and Coos Bay. Though there are no major urban areas on the Oregon coast (most coastal 'cities' have populations of fewer than 10,000 ), the larger coastal communities are located near these estuaries due to the historical significance of these areas as commercial ports for the fishing and timber industries. It's difficult to ascertain whether general population density, or the presence of commercial fishing hubs in these estuarine port communities contribute to increased strandings in these areas, or whether the productivity of these areas-the same factors that make them viable fishing hubsattract sea lions that are 'following the food' and lead to greater likelihood of interactions.

Strandings in the PSU region also correlate with commercial fisheries activity. An unusually high number of HI strandings in December 2008 and January 2009 occurred during the Dungeness crab season, which typically opens on December $1^{\text {st }}$. The commercial salmon season (excluding Coho) generally opens on April $1^{\text {st }}$ and continues through September. In the waters off northern Oregon and 
southern Washington, the Coho salmon season opens in July and remains open through September or until quotas are met. All PSU strandings correlate with the Chinook salmon fishery, as do PSU HI strandings, suggesting that interactions may be related to resource competition between sea lions and fisheries. PSU California sea lion strandings also correlate with the Coho salmon fishery, with both peaking in September. Determining whether HI strandings are directly related to increased competition for scarce resources in a particular fishery may be useful to fisheries management as well as understanding the movement and behavior of sea lions (Greig et al. 2005). An objective analysis of human interaction with stranded marine mammals will be important as discussions of the health of marine ecosystems become more urgent and political. Future efforts should be aimed at increasing stranding network capacity to necropsy all animals, and further study of the foraging behavior of sea lions in Oregon and southern Washington would be useful in determining what comprises the majority of the animals' diets, the degree to which sea lions prey on salmon, and how they change their foraging behavior under different ocean conditions.

This thesis attempts to establish baseline information regarding spatial and temporal trends of sea lion strandings in Oregon and southern Washington, and to identify factors that may be associated with those trends. As the effects of climate change manifest in the oceans, impacts will be seen at multiple trophic levels. Marine researchers and managers are realizing the importance of monitoring these impacts in order to better understand the underlying mechanisms of changing ocean conditions. Marine mammals, particularly pinnipeds that are highly visible on 
land, are important sentinel species in this changing system and stranding patterns can be indicators of how these changing conditions are manifesting at the top of the food web.

\begin{tabular}{|cr|}
\hline Month-Year & Astoria Peak Haulout \\
\hline Sep-06 & 165 \\
\hline Oct-07 & 192 \\
\hline Sep-08 & 196 \\
\hline Aug-09 & 342 \\
\hline Sep-10 & 328 \\
\hline Aug-11 & 302 \\
\hline Apr-12 & 240 \\
\hline Apr-13 & 739 \\
\hline Mar-14 & 1420 \\
\hline Mar-15 & 2340 \\
\hline
\end{tabular}

Table 1: Peak annual haulout counts at East Mooring Basin, Astoria, Oregon (PSMFC unpublished data). 


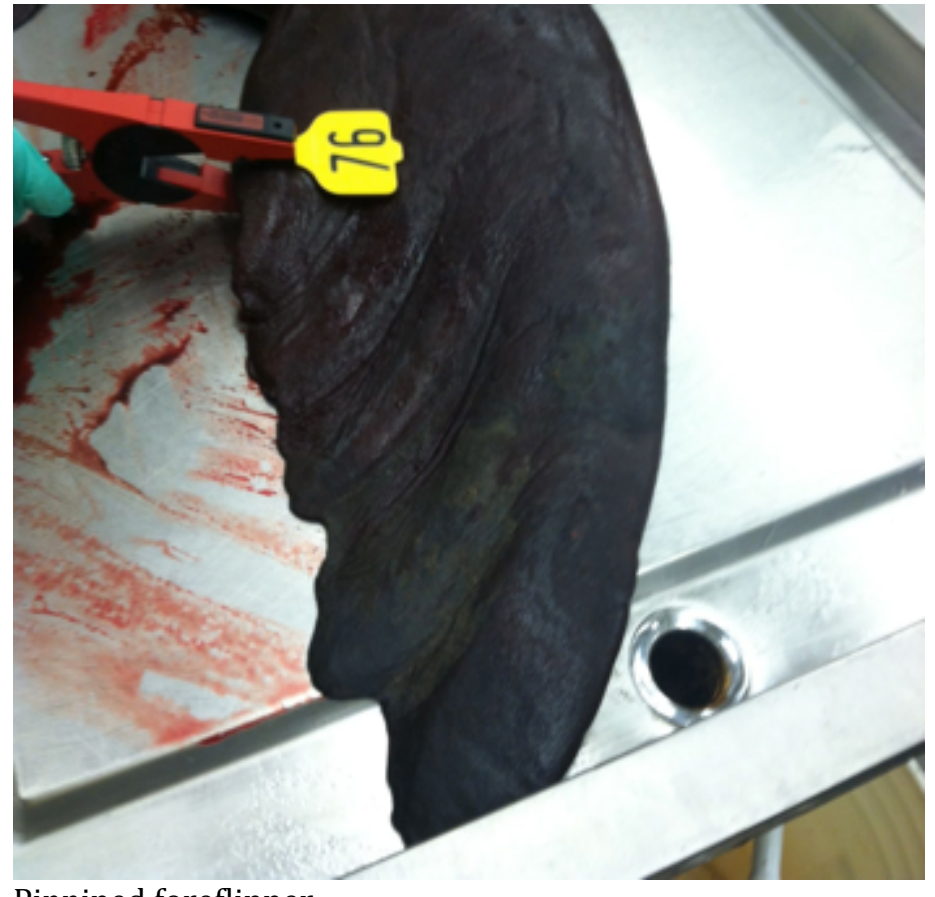

Pinniped foreflipper

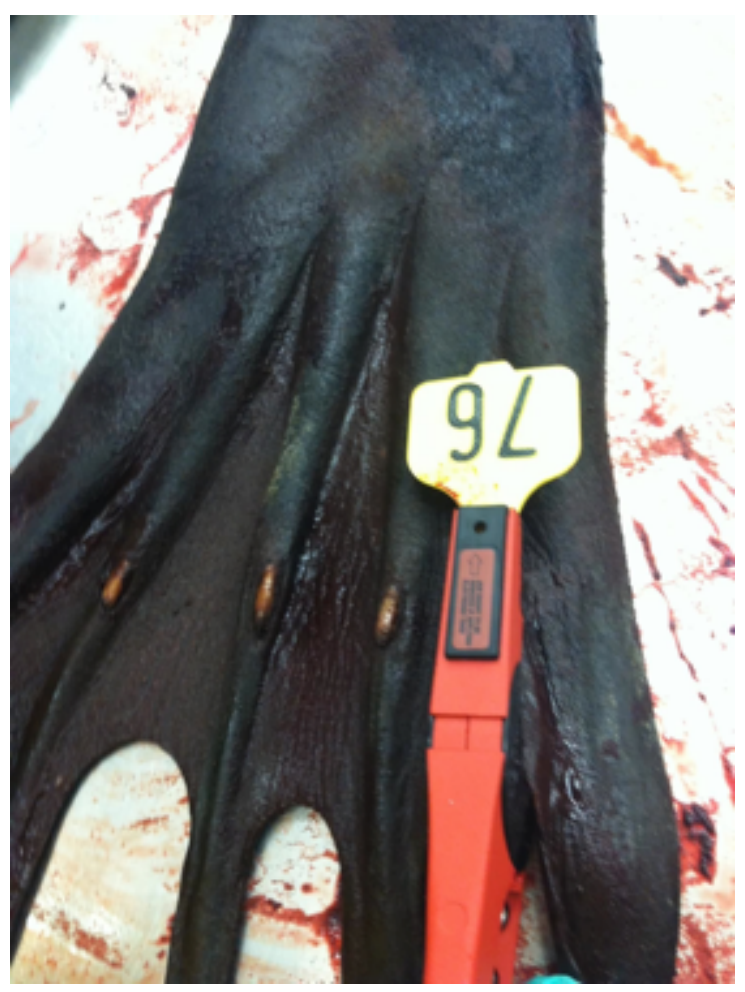

Pinniped rear flipper

Figure 4.1: Bycatch tagging protocols 


\section{References}

Aldstadt, J. (2010). Spatial clustering. In M. Fischer \& A. Getis (Eds.), Handbook of applied spatial analysis (pp. 279-300). Heidelberg, Germany: Springer.

Aurioles-Gamboa, D. \& Hernandez-Camacho, J. 2015. Zalophus californianus. The IUCN Red List of Threatened Species 2015. Retrieved from http://dx.doi.org/10.2305/IUCN.UK.2015-4.RLTS.T41666A45230310.en

Bjorge, A., Bekkby, T., Bakkestuen, V., \& Framstad, E. (2002). Interactions between harbour seals, Phoca vitulina, and fisheries in complex coastal waters explored by Geographic Information System (GIS) and energetics modelling. ICES Journal of Marine Science: Journal du Conseil, 59(1), 29-42.

Bolstead, P. (2008). GIS Fundamentals: A First Text on Geographic Information Systems (pp. 1-11), (3rd ed.). White Bear Lake, Minnesota: Eider Press.

Bond, N. A., Cronin, M. F., Freeland, H., \& Mantua, N. (2015). Causes and impacts of the 2014 warm anomaly in the NE Pacific. Geophysical Research Letters, 42(9), 3414-3420.

Bossart, G. D. (2006). Marine mammals as sentinel species for oceans and human health. Oceanography, 19(2), 134-137.

Breman, J. (2002). Marine geography: GIS for the oceans and seas (pp. 20-21). Redlands, CA: ESRI, Inc.

Brodeur, R. D., Ralston, S., Emmett, R. L., Trudel, M., Auth, T. D., \& Phillips, A. J. (2006). Anomalous pelagic nekton abundance, distribution, and apparent recruitment in the northern California Current in 2004 and 2005. Geophysical Research Letters, 33(22).

Brown, R., Jeffries, S., Wright, B., Tennis, M., Gearin, P., Riemer, S., Hatch, D. (2007). Field report: 2007 pinniped research and management activities at Bonneville Dam. US Army Corps of Engineers, Portland District, Fisheries Field Unit Bonneville Lock and Dam Cascade Locks, Oregon.

Calkins, D. G., Pitcher, K. W., Schneider, K. B., \& Murray, N. (1982). Population assessment, ecology and trophic relationships of Steller sea lions in the Gulf of 
Alaska. Outer Continental Shelf Environmental Assessment, US Department of the Interior, Bureau of Land Management.

Carretta, J. V., Forney, K. A., Lowry, M. S., Barlow, J., Baker, J., Johnston, D., Mattila, D. K. (2009). US Pacific marine mammal stock assessments: 2009. National Marine Fisheries Service, US Fish and Wildlife Service.

Dunlap, W. S. (1995). The influence of El Ninos on pinniped strandings along the California coast 1982-1992. M.S. Thesis, University of San Diego, San Diego, CA.

Geraci, J. R., \& Lounsbury, V. J. (2005). Marine mammals ashore: a field guide for strandings. National Aquarium in Baltimore.

Getis, A., \& Ord, J. K. (1996). Local spatial statistics: an overview. In Spatial analysis: modelling in a GIS environment, 374. New York, NY: John Wiley \& Sons.

Greig, D. J., Gulland, F. M. D., \& Kreuder, C. (2005). A Decade of Live California Sea Lion (Zalophus californianus) Strandings Along the Central California Coast: Causes and Trends, 1991-2000. Aquatic Mammals, 31(1), 11-22.

Harris, D. E., \& Gupta, S. (2006). GIS-based analysis of ice-breeding seal strandings in the Gulf of Maine. Northeastern Naturalist, 13(3), 403-420.

Johnson, S. L. (1988). The effects of the 1983 El Nino on Oregon's coho (Oncorhynchus kisutch) and chinook (O. tshawytscha) salmon. Fisheries Research, 6(2), 105-123.

Keledjian, A., Mesnick, Sarah. (2013). The Impacts of El Nino Conditions on California Sea Lion Fisheries Interactions: Predicting Spatial and Temporal Hotspots Along the California Coast. Aquatic Mammals, 39(3, 221-232.

Knap, A., Dewailly, É., Furgal, C., Galvin, J., Baden, D., Bowen, R. E., Ford, T. (2002). Indicators of ocean health and human health: developing a research and monitoring framework. Environmental Health Perspectives, 110(9), 839.

Maina, J., Venus, V., McClanahan, T. R., \& Ateweberhan, M. (2008). Modelling susceptibility of coral reefs to environmental stress using remote sensing data and GIS models. Ecological Modelling, 212(3), 180-199.

Mantua, N. J., Hare, S. R., Zhang, Y., Wallace, J. M., \& Francis, R. C. (1997). A Pacific interdecadal climate oscillation with impacts on salmon production. Bulletin of the American Meteorological Society, 78(6), 1069-1079. 
McCullagh, M. J. (2006). Detecting hotspots in time and space. ISG06.

Moore, M., Early, Greg; Touhey, Kathleen; Barco, Susan; Gulland, Frances; Wells, Randall. (2007). Rehabilitation and release of marine mammals in the United States: Risks and Benefits. Marine Mammal Science, 23(4), 731-750.

National Marine Fisheries Service. 2013. Status Review of The Eastern Distinct Population Segment of Steller Sea Lion (Eumetopias jubatus). Protected Resources Division, Alaska Region, National Marine Fisheries Service, 709 West 9th St, Juneau, Alaska 99802.

NOAA Fisheries (2015). Steller Sea Lion (Eumetopias jubatus). Retrieved from http://www.fisheries.noaa.gov/pr/species/mammals/sealions/steller-sea-lion.html. NOAA Protected Resources (2014). 2013-2015 California Sea Lion Unusual Mortality Event in California. Retrieved from http://www.nmfs.noaa.gov/pr/health/mmume/californiasealions2013.html.

Norberg, B., Stansell, R., Griffin, G., Brown, R., Jeffries, S., \& Gearin, P. (2005). Field report-preliminary observations of non-lethal deterrence measures for California sea lion predation at Bonneville Dam.

Norman, S. A., Huggins, J., Carpenter, T. E., Case, J. T., Lambourn, D. M., Rice, J., Duffield, D. A. (2012). The application of GIS and spatiotemporal analyses to investigations of unusual marine mammal strandings and mortality events. Marine Mammal Science, 28(3), E251-E266.

Odell, D. K. (1981). California sea lion, Zalophus californianus (Lesson, 1828). Handbook of Marine Mammals, 1, 67-97.

Pearcy, W. G., \& Schoener, A. (1987). Changes in the marine biota coincident with the 1982-1983 El Niño in the northeastern subarctic Pacific Ocean. Journal of Geophysical Research: Oceans, 92(C13), 14417-14428.

Peltier, H., Dabin, W., Daniel, P., Van Canneyt, O., Dorémus, G., Huon, M., \& Ridoux, V. (2012). The significance of stranding data as indicators of cetacean populations at sea: modelling the drift of cetacean carcasses. Ecological Indicators, 18, 278290. 
Philander, S. G. H. (1983). El Nino Southern Oscillation phenomena. Nature, 302, 295301.

Pitcher, K. W., Olesiuk, P. F., Brown, R. F., Lowry, M. S., Jeffries, S. J., Sease, J. L., Lowry, L. F. (2007). Abundance and distribution of the eastern North Pacific Steller sea lion (Eumetopias jubatus) population. Fishery Bulletin, 105(1), 102-116.

Prasannakumar, V., Vijith, H., Charutha, R., \& Geetha, N. (2011). Spatio-temporal clustering of road accidents: GIS based analysis and assessment. Procedia-Social and Behavioral Sciences, 21, 317-325.

Schwing, F. B., Husby, D. M., Garfield, N., \& Tracy, D. E. (1991). Mesoscale oceanic response to wind events off central California in spring 1989: CTD surveys and AVHRR imagery. Calif. Coop. Oceanic Fish. Invest. Rep, 32, 47-62.

Stansell, R. J., Gibbons, K. M., \& Nagy, W. T. (2010). Evaluation of pinniped predation on adult salmonids and other fish in the Bonneville Dam tailrace, 2008-2010. salmonrecovery.gov. Retrieved from http://www.salmonrecovery.gov/Files/2011 APR files/New folder(2)/Stansell_et_al._2011_S1-2008-2010_Pinniped_Report.

Szteren, D., Aurioles, D., \& Gerber, L. R. (2006). Population status and trends of the California sea lion (Zalophus californianus) in the Gulf of California, Mexico. Sea Lions of the World. Alaska Sea Grant College Program, Lowell Wakefield Fisheries Symposium Series, Rhode Island.

Weise, M. J., Costa, D. P., \& Kudela, R. M. (2006). Movement and diving behavior of male California sea lion (Zalophus californianus) during anomalous oceanographic conditions of 2005 compared to those of 2004.

Zhang, C., Luo, L., Xu, W., \& Ledwith, V. (2008). Use of local Moran's I and GIS to identify pollution hotspots of $\mathrm{Pb}$ in urban soils of Galway, Ireland. Science of the Total Environment, 398(1), 212-221. 


\section{Appendix A: Level A form}

MARINE MAMMAL STRANDING REPORT - LEVEL A DATA

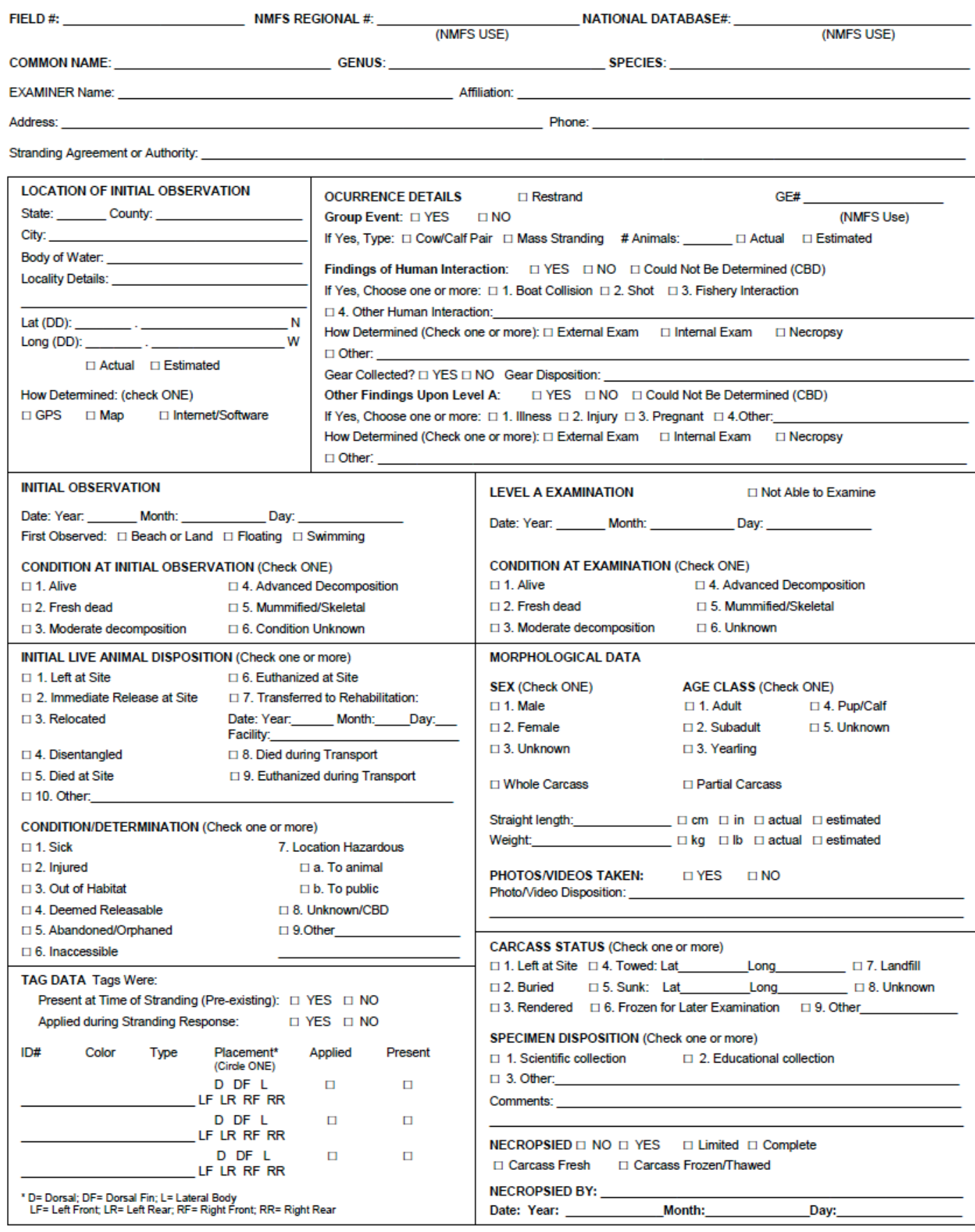




\section{Appendix A: Level A Form}

ADDITIONAL REMARKS

ADDITIONAL IDENTIFIER:

(If animal is restranded, please indicate any previous field numbers here)

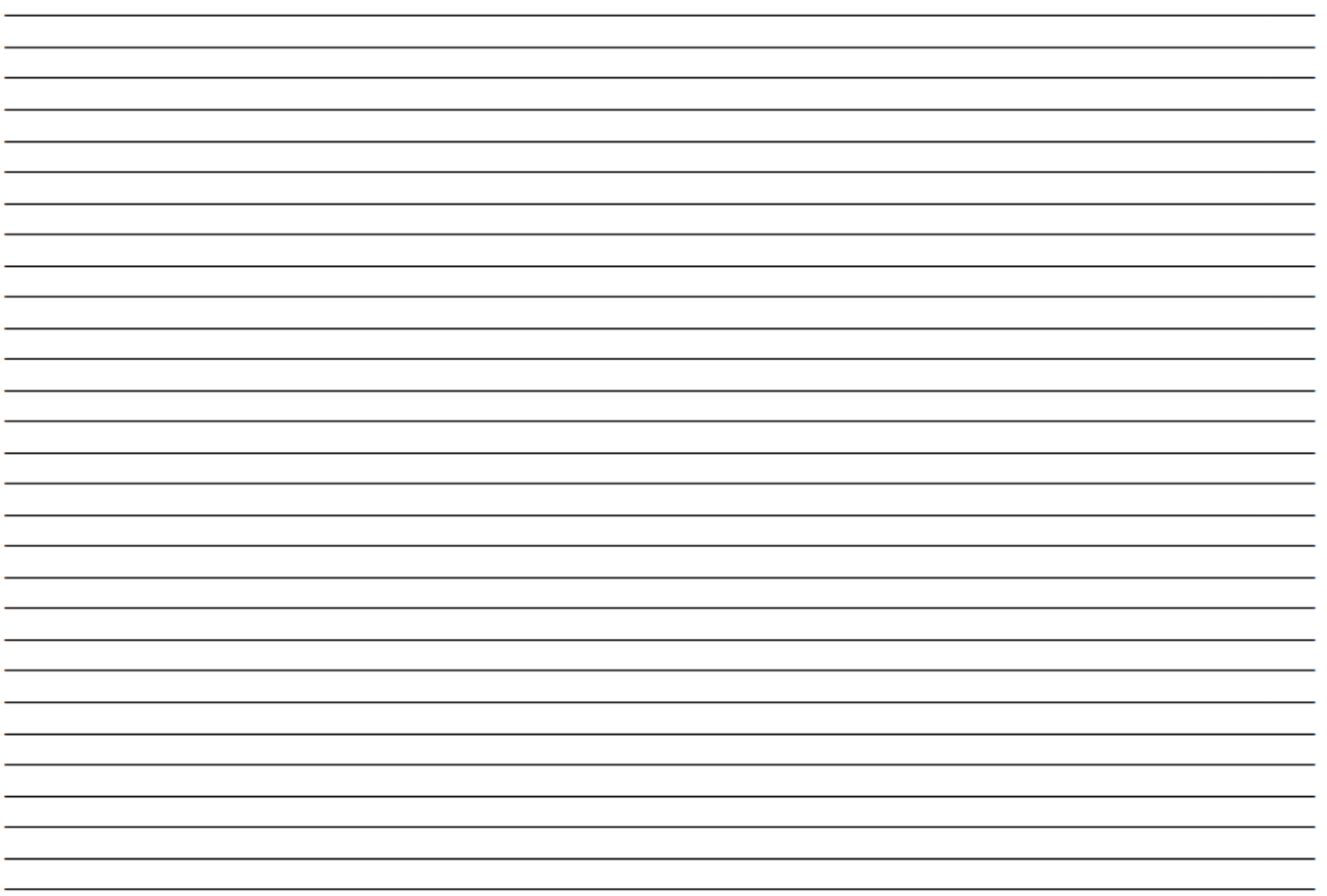

DISCLAIMER

THESE DATA SHOULD NOT BE USED OUT OF CONTEXT OR WITHOUT VERIFICATION. THIS SHOULD BE STRICTLY ENFORCED WHEN REPORTING SIGNS OF HUMAN INTERACTION DATA.

DATA ACCESS FOR LEVEL A DATA

UPON WRITTEN REQUEST, CERTAIN FIELDS OF THE LEVEL A DATA SHEET WILL BE RELEASED TO THE REQUESTOR PROVIDED THAT THE REQUESTOR CREDIT THE STRANDING NETWORK AND THE NATIONAL MARINE FISHERIES SERVICE. THE NATIONAL MARINE FISHERIES SERVICE WILL NOTIFY THE CONTRIBUTING STRANDING NETWORK MEMBERS THAT THESE DATA HAVE BEEN REQUESTED AND THE INTENT OF USE. ALL OTHER DATA WILL BE RELEASED TO THE REQUESTOR PROVIDED THAT THE REQUESTOR OBTAIN PERMISSION FROM THE CONTRIBUTING STRANDING NETWORK AND THE NATIONAL MARINE FISHERIES SERVICE.

\section{PAPERWORK REDUCTION ACT INFORMATION}

PUBLIC REPORTING BURDEN FOR THE COLLECTION OF INFORMATION IS ESTIMATED TO AVERAGE 30 MINUTES PER RESPONSE, INCLUDING THE TIME FOR REVIEWING INSTRUCTIONS, SEARCHING EXISTING DATA SOURCES, GATHERING AND MAINTAINING THE DATA NEEDED, AND COMPLETING AND REVIEWING THE COLLECTION OF INFORMATION. SEND COMMENTS REGARDING THIS BURDEN ESTIMATE OR ANY OTHER ASPECT OF THE COLLECTION INFORMATION, INCLUDING SUGGESTIONS FOR REDUCING THE BURDEN TO: CHIEF, MARINE MAMMAL AND SEA TURTLE CONSERVATION DIVISION, OFFICE OF PROTECTED RESOURCES, NOAA FISHERIES, 1315 EAST-WEST HIGHWAY, SILVER SPRING, MARYLAND 20910. NOT WITHSTANDING ANY OTHER PROVISION OF THE LAW, NO PERSON IS REQUIRED TO RESPOND, NOR SHALL ANY PERSON BE SUBJECTED TO A PENALTY FOR FAILURE TOLLECTION OF INFORMATION DISPLAYS A CURRENTLY VALID OFFICE OF MANAGEMENT AND BUDGET (OMB) CONTROL NUMBER.

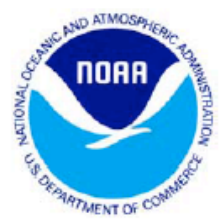


Appendix B: Table of fisheries data: pounds landed; fisheries assigned ' 0 ' when not in peak season, ' 1 ' indicates highest effort and landings (Source: Oregon Department of Fish and Wildlife)

\begin{tabular}{|c|c|c|c|c|c|c|c|}
\hline YEAR & MONTH & соно & CHINOOK & CRAB & COHO Y/N & CHINOOK Y/N & CRAB Y/N \\
\hline 2006 & Jan & 0 & 16 & 9540402 & 0 & 0 & 1 \\
\hline 2006 & Feb & 0 & 741 & 10403885 & 0 & 0 & 1 \\
\hline 2006 & Mar & 0 & 10745 & 4132590 & 0 & 0 & 0 \\
\hline 2006 & Apr & 0 & 17590 & 1818817 & 0 & 0 & 0 \\
\hline 2006 & May & 0 & 185465 & 1037248 & 0 & 1 & 0 \\
\hline 2006 & Jun & 0 & 218026 & 398231 & 0 & 1 & 0 \\
\hline 2006 & Jul & 120 & 99292 & 192698 & 0 & 0 & 0 \\
\hline 2006 & Aug & 24876 & 161903 & 63275 & 1 & 1 & 0 \\
\hline 2006 & Sep & 380230 & 385708 & 0 & 1 & 1 & 0 \\
\hline 2006 & Oct & 99004 & 173008 & 6338 & 1 & 1 & 0 \\
\hline 2006 & Nov & 0 & 16550 & 4669 & 0 & 0 & 0 \\
\hline 2006 & Dec & 0 & 4357 & 5696904 & 0 & 0 & 1 \\
\hline 2007 & Jan & 0 & 23 & 5889817 & 0 & 0 & 1 \\
\hline 2007 & Feb & 0 & 3143 & 1293246 & 0 & 0 & 0 \\
\hline 2007 & Mar & 0 & 36863 & 1322737 & 0 & 0 & 0 \\
\hline 2007 & Apr & 0 & 62791 & 396068 & 0 & 0 & 0 \\
\hline 2007 & May & 0 & 151875 & 363988 & 0 & 1 & 0 \\
\hline 2007 & Jun & 111 & 139908 & 139687 & 0 & 1 & 0 \\
\hline 2007 & Jul & 7840 & 65505 & 66442 & 0 & 0 & 0 \\
\hline 2007 & Aug & 102235 & 285049 & 50151 & 1 & 1 & 0 \\
\hline 2007 & Sep & 99781 & 210465 & 1477 & 1 & 1 & 0 \\
\hline 2007 & Oct & 111145 & 64029 & 7712 & 1 & 0 & 0 \\
\hline 2007 & Nov & 0 & 9994 & 2874 & 0 & 0 & 0 \\
\hline 2007 & Dec & 0 & 49 & 7472036 & 0 & 0 & 1 \\
\hline 2008 & Jan & 0 & 0 & 2767251 & 0 & 0 & 1 \\
\hline 2008 & Feb & 0 & 361 & 997373 & 0 & 0 & 0 \\
\hline 2008 & Mar & 8 & 3197 & 407344 & 0 & 0 & 0 \\
\hline 2008 & Apr & 0 & 56453 & 311523 & 0 & 0 & 0 \\
\hline 2008 & May & 0 & 99801 & 179898 & 0 & 0 & 0 \\
\hline 2008 & Jun & 0 & 52177 & 90975 & 0 & 0 & 0 \\
\hline 2008 & Jul & 145 & 35562 & 68926 & 0 & 0 & 0 \\
\hline 2008 & Aug & 8998 & 360919 & 46877 & 0 & 1 & 0 \\
\hline 2008 & Sep & 443412 & 605299 & 0 & 1 & 1 & 0 \\
\hline 2008 & Oct & 106416 & 69095 & 8240 & 1 & 0 & 0 \\
\hline 2008 & Nov & 0 & 3668 & 0 & 0 & 0 & 0 \\
\hline 2008 & Dec & 0 & 0 & 8990394 & 0 & 0 & 1 \\
\hline
\end{tabular}




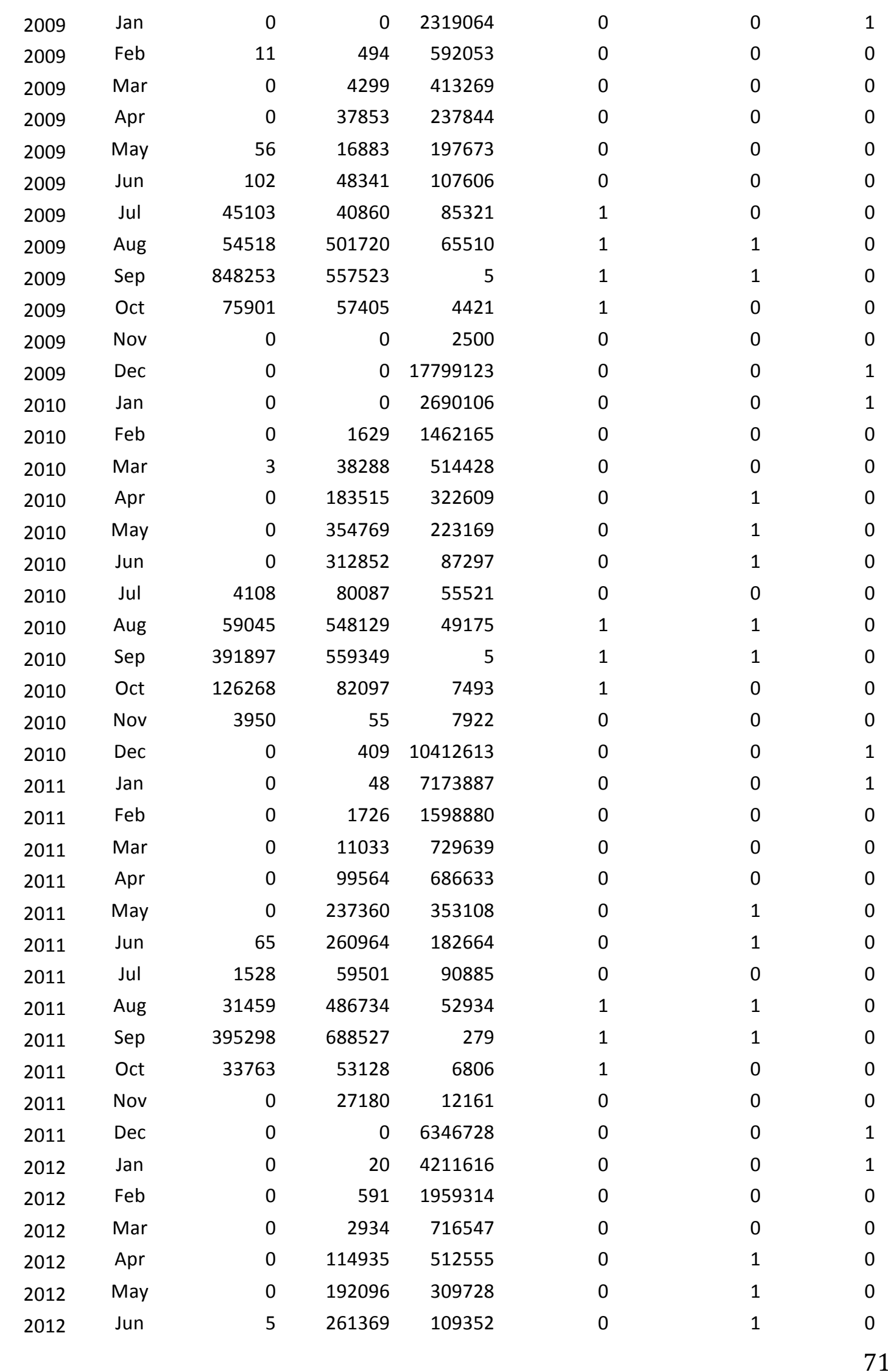




$\begin{array}{lcrrrlll}2012 & \text { Jul } & 180 & 73830 & 60755 & 0 & 0 & 0 \\ 2012 & \text { Aug } & 6214 & 506245 & 28475 & 0 & 1 & 0 \\ 2012 & \text { Sep } & 83475 & 512175 & 9 & 1 & 1 & 0 \\ 2012 & \text { Oct } & 13151 & 136459 & 4462 & 1 & 1 & 0 \\ 2012 & \text { Nov } & 0 & 12504 & 14263 & 0 & 0 & 0 \\ 2012 & \text { Dec } & 0 & 493 & 662241 & 0 & 0 & 0 \\ 2013 & \text { Jan } & 0 & 0 & 12434403 & 0 & 0 & 1 \\ 2013 & \text { Feb } & 0 & 275 & 2525173 & 0 & 0 & 0 \\ 2013 & \text { Mar } & 0 & 7416 & 1533081 & 0 & 0 & 0 \\ 2013 & \text { Apr } & 0 & 127341 & 4788888 & 0 & 0 & 0 \\ 2013 & \text { May } & 0 & 134181 & 296139 & 0 & 0 & 0 \\ 2013 & \text { Jun } & 4 & 177744 & 138045 & 0 & 0 & 0 \\ 2013 & \text { Jul } & 394 & 182815 & 81900 & 0 & 0 & 0 \\ 2013 & \text { Aug } & 13701 & 1205832 & 42018 & 1 & 1 & 0 \\ 2013 & \text { Sep } & 217155 & 1188417 & 4 & 1 & 1 & 0 \\ 2013 & \text { Oct } & 43407 & 174556 & 2 & 1 & 0 & 0 \\ 2013 & \text { Nov } & 0 & 27674 & 5582 & 0 & 0 & 0 \\ 2013 & \text { Dec } & 0 & 0 & 8493274 & 0 & 0 & 1 \\ 2014 & \text { Jan } & 0 & 4 & 3731617 & 0 & 0 & 1 \\ 2014 & \text { Feb } & 0 & 179 & 956300 & 0 & 0 & 0 \\ 2014 & \text { Mar } & 2 & 5606 & 504583 & 0 & 0 & 0 \\ 2014 & \text { Apr } & 0 & 262056 & 269559 & 0 & 1 & 0 \\ 2014 & \text { May } & 0 & 893419 & 213153 & 0 & 1 & 0 \\ 2014 & \text { Jun } & 91 & 480304 & 88332 & 0 & 1 & 0 \\ 2014 & \text { Jul } & 11936 & 359068 & 109337 & 1 & 1 & 0 \\ 2014 & \text { Aug } & 16583 & 1375263 & 56658 & 1 & 0 \\ 2014 & \text { Sep } & 1227655 & 1291954 & 2 & 1 & 0 & 0 \\ 2014 & \text { Oct } & 278871 & 166813 & 0 & 1 & 0 & 0 \\ 2014 & \text { Nov } & 106 & 10357 & 3720 & 0 & 0 & 0 \\ 2014 & \text { Dec } & 0 & 20 & 5970080 & 0 & 0 & 0 \\ & & & & 0 & 0 & 0 \\ 2\end{array}$

